I NTER NATIONAL MONETARY FUND

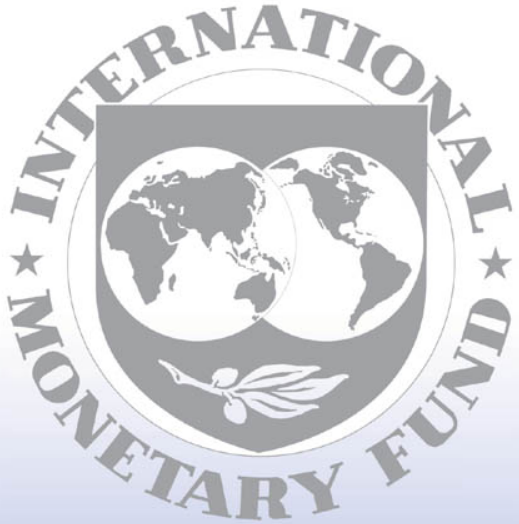

Staff

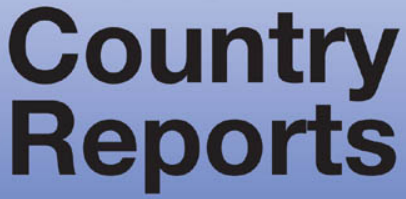




\section{Former Yugoslav Republic of Macedonia: First Review Under the Stand-By Arrangement, and Requests for Waiver of Performance Criteria, and Extension of Repurchase Expectations-Staff Report; Staff Statement; Press Release on the Executive Board Discussions; and Statement by the Executive Director for the Former Yugoslav Republic of Macedonia}

In the context of the first review under the Stand-By Arrangement for the former Yugoslav Republic of Macedonia and its request for a waiver of performance criteria, and extension of repurchase expectations, the following documents have been released and are included in this package:

- $\quad$ the staff report for the First Review Under the Stand-By Arrangement and Request for Waiver of Performance Criteria, and Extension of Repurchase Expectations prepared by a staff team of the IMF, following discussions that ended on February 14, 2006, with the officials of the former Yugoslav Republic of Macedonia on economic developments and policies. Based on information available at the time of these discussions, the staff report was completed on April 3, 2006. The views expressed in the staff report are those of the staff team and do not necessarily reflect the views of the Executive Board of the IMF.

- $\quad$ a staff statement of April 19, 2006 updating information on recent developments.

- $\quad$ a Press Release summarizing the views of the Executive Board as expressed during its April 19, 2006 discussion of the staff report that concluded the review.

- $\quad$ a statement by the Executive Director for the former Yugoslav Republic of Macedonia.

The documents listed below have been or will be separately released.

Letter of Intent sent to the IMF by the authorities of the former Yugoslav Republic of Macedonia* Technical Memorandum of Understanding*

*Also included in Staff Report

The policy of publication of staff reports and other documents allows for the deletion of market-sensitive information.

To assist the IMF in evaluating the publication policy, reader comments are invited and may be sent by e-mail to publicationpolicy@imf.org.

Copies of this report are available to the public from

International Monetary Fund • Publication Services

$70019^{\text {th }}$ Street, N.W. • Washington, D.C. 20431

Telephone: (202) 623-7430 • Telefax: (202) 623-7201

E-mail: publications@imf.org Internet: http://www.imf.org

Price: $\$ 15.00$ a copy

\section{International Monetary Fund}

Washington, D.C. 
This page intentionally left blank

CInternational Monetary Fund. Not for Redistribution 
INTERNATIONAL MONETARY FUND

FORMER YUGOSLAV REPUBLIC OF MACEDONIA

\section{First Review Under the Stand-By Arrangement, Requests for Waiver of Performance Criteria, and Extension of Repurchase Expectations}

Prepared by the European Department

(In consultation with other departments)

Approved by Susan Schadler and Scott Brown

April 3, 2006

Stand-By Arrangement. The Fund supports FYR Macedonia's economic program with a three-year SDR 51.7 million Stand-By Arrangement (75 percent of quota), of which SDR 10.5 million has been purchased so far. An additional SDR 3.4 million becomes available on completion of this review. However, the authorities do not plan to make any more purchases under the arrangement, beyond the initial purchase.

Extension of Repurchase Expectations. In view of remaining vulnerabilities, and to smooth the debt service profile, the authorities are requesting that the existing repurchase expectations between end-September 2006 and end-December 2007 be extended to an obligations basis.

Discussions. During January 31-February 14, 2006 the staff team held discussions with Prime Minister Bučkovski, Finance Minister Popovski, Minister of Economy Besimi, Minister of Health Dimov, National Bank of the Republic of Macedonia Governor Gošev, other senior officials, and representatives of the banking, business, political and international communities.

Staff. Team members included Mark Griffiths (head), Christine Dieterich and Christopher Marsh (all EUR), Alexander Pivovarsky (FAD), Alessandro Giustiniani (MFD), Eva Gutierrez (PDR) and Kevin Ross (Resident Representative).

Publication. The Macedonian authorities have not yet decided on the publication of this staff report. 


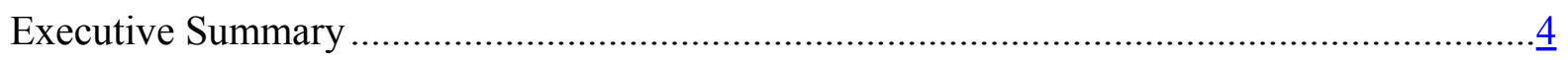

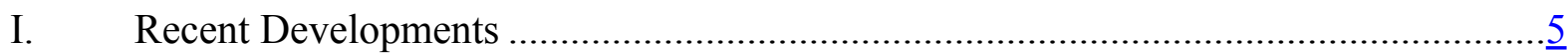

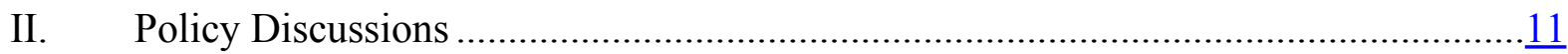

A. Macroeconomic Framework ……………….........................................13

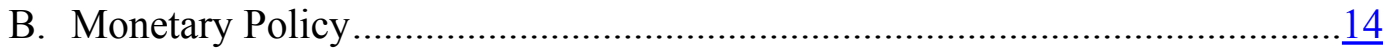

C. Fiscal Policy and Reforms .......................................................................

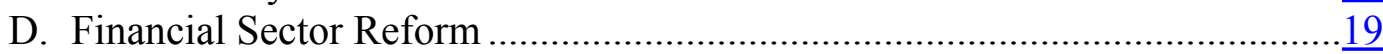

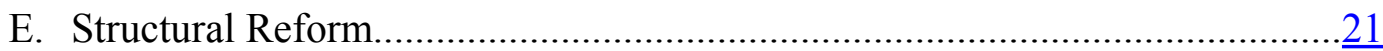

III. Program Modalities and Risks ...........................................................................

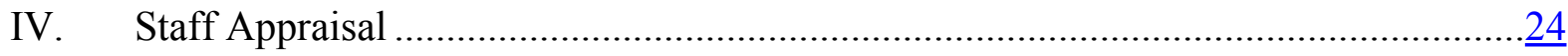

Text Boxes

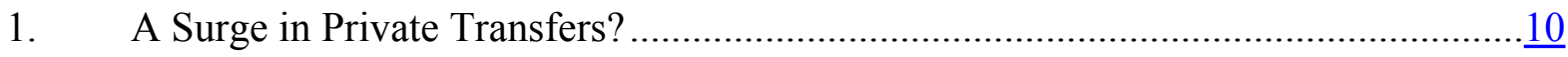

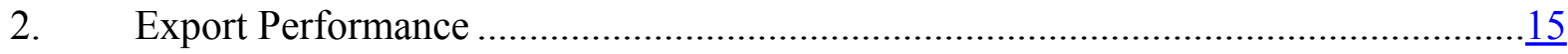

Figures

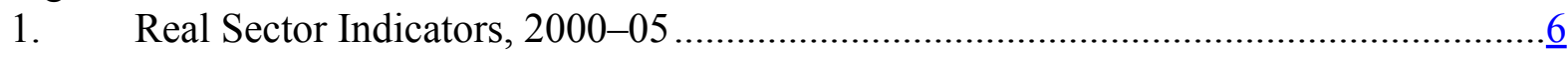

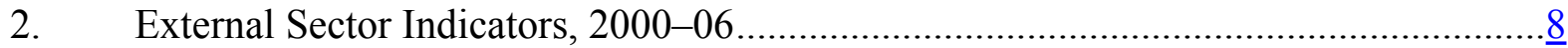

3. Financial Market Developments, 2004-06 …………........................................

4. $\quad$ Money and Credit Developments, 2001-06 ……...............................................

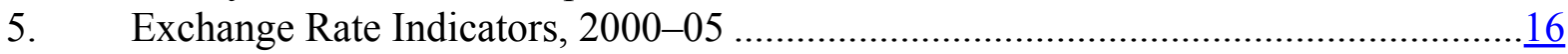

6. Banking Sector Developments, 2001-05 ............................................................

Tables

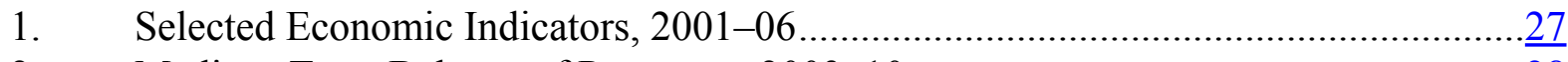

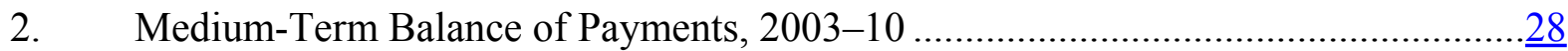

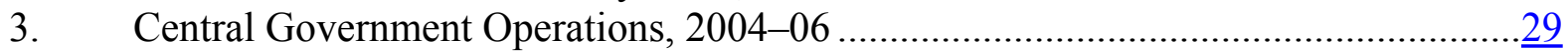

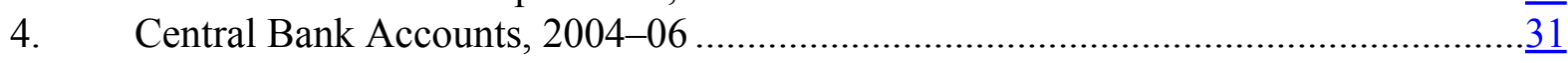

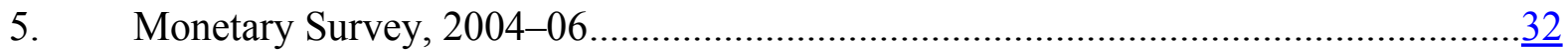

6. Requests for Waivers and Revisions to Program Targets...........................................33

7. External Financing Requirements and Sources, 2003-09 …….................................

8. Indicators of Financial and External Vulnerability, 2001-05 …...............................

9. Indicators of Capacity to Repay the Fund, 2003-10 ................................................ 
Appendices

I. $\quad$ EU Candidate Status: A Roadmap for Reform ................................................

II. The Problem of Health Sector Arrears ........................................................................ $\frac{38}{41}$

III. Fund Relations .......................................................................................... 41

IV. World Bank Relations..................................................................................

Attachment I. Letter of Intent.. ........................................................................

Attachment I-Tables

1. Monetary Quantitative Performance Criteria and Indicative Targets........................64

2. Structural Conditionality, 2005-07 ............................................................. $\frac{66}{6}$

Attachment I-Annexes

A. Technical Memorandum of Understanding ........................................................69 


\section{EXECUTIVE SUMMARY}

Macroeconomic performance remains strong. Through end-December, the authorities met all of the program's quantitative performance criteria, save for the target on Health Insurance Fund arrears (and even in this difficult area there has been some improvement). Growth has remained steady at around 4 percent; inflation is low, though tax increases could raise it this year to 2 percent; and, though there are measurement problems with private transfers, last year's current account deficit fell to around 1 1/2 percent of GDP. Financial market conditions are also getting better. Gross reserves have risen above $€ 1$ billion, allowing interest rates on NBRM bills to fall since November from 10 to 7 percent.

To complete the First Review, the authorities have committed to strong policies, including measures to correct for delays in the program's structural reforms:

- $\quad$ Fiscal policy. The budget again overperformed the program target in 2005, with investment shortfalls contributing to a surplus of 0.3 percent of GDP. The authorities are committed to meeting this year's 0.6 percent of GDP deficit target. A new tobacco tax will help pay for existing (underfinanced) national health programs.

- $\quad$ Monetary policy. The revised program raises the end-2006 NIR target by $€ 100$ million, locking in two-thirds of the end-2005 overperformance, to protect the program from excessive monetary expansion. The privatization adjuster is increased by $€ 50$ million, to address uncertainties over the timing and size of receipts.

- $\quad$ Banking law. The NBRM law will be revised by June to strengthen the governor's powers, and to limit the right to undo financial supervision decisions. The authorities missed the end-December structural performance criterion on submitting a new Banking Law: an agreed draft will now be ready by September. The delay will allow for a more comprehensive revision and for the incorporation of MFD and LEG technical assistance. The staff therefore supports the authorities' waiver request.

- Health sector arrears. Using the Fund's definition, arrears are less than previously reported and fell in the last quarter of 2005; even so, they are above end-2004 levels, which exceeds the program's performance criterion. However, with signs that last year's reforms are starting to work, and with new controls in the Letter of Intent, the staff recommends a waiver.

- $\quad$ Privatization. The authorities have privatized the electricity distribution company in a transparent bidding process. Sale of the bulk of the government's 49 percent stake in the telecoms company is likely to be delayed beyond June (the program goal), in part because the majority private owner can influence the terms of the sale. The mission expressed concern over delays in increasing electricity prices, weaknesses in the energy regulator, and delays in issuing the tender for the telecom sale. High telecommunications charges may also be impeding growth; consistent with their EU requirements, the authorities have committed to liberalizing this sector. 


\section{RECENT DEVELOPMENTS}

1. FYR Macedonia's macroeconomic performance in 2005 was better than envisaged under the original program:

- $\quad$ Real GDP growth reached around 4 percent for the second consecutive year, and employment has started to increase (Figure 1, Table 1). Excluding sectors where output is proxied by employment (which ignores productivity growth), growth was even higher, at around 6 percent. Growth was driven by strong exports, while tight fiscal policy and high interest rates at end-2004 moderated domestic demand and imports. Labor market liberalization also helped boost employment.

Alternative Measures of Real GDP Growth

\begin{tabular}{lrrrr}
\hline & 2003 & 2004 & 2005 & 2006 \\
\hline & & & & \\
Total GDP growth & 2.8 & 4.1 & 4.0 & 4.0 \\
Partial GDP growth 1/ & 3.8 & 2.9 & 6.2 & 4.7 \\
\hline
\end{tabular}

$1 /$ Excludes sectors where employment is used to proxy output (government and financial services)

- $\quad$ Despite higher oil prices, the price level was broadly stable in 2005. Though oil prices raised consumer prices by $1 / 2$ percent, lower food prices (due to WTO-required tariff reductions and foreign retail competition) more than offset this in 2005 . Higher tobacco taxes raised headline inflation above 2 percent in January 2006, though this should only be a one-time price level effect.

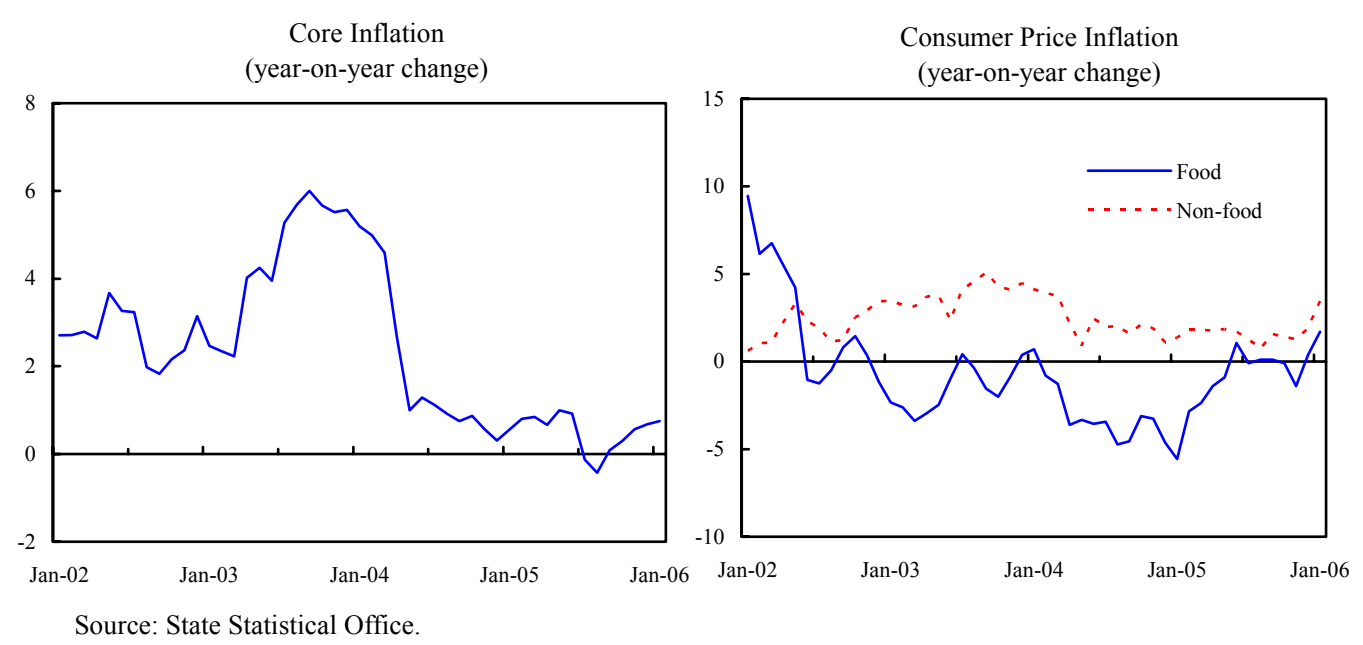


Figure 1. FYR Macedonia: Real Sector Indicators, 2000-05

GDP growth in 2005 was in line with previous

years...

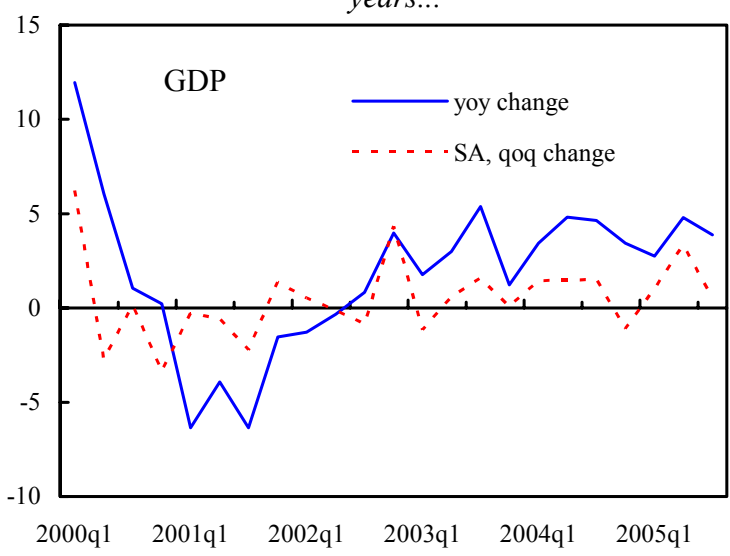

While industrial production weakened at the end of $2005 \ldots$

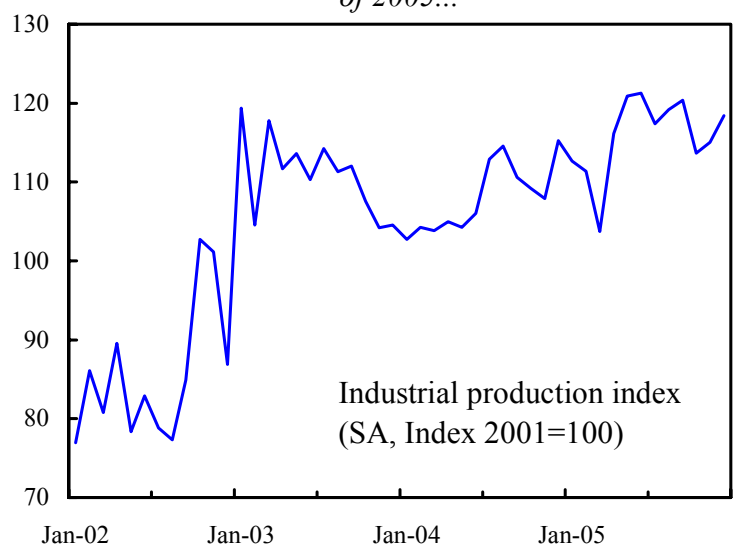

... as does confidence in the construction sector...

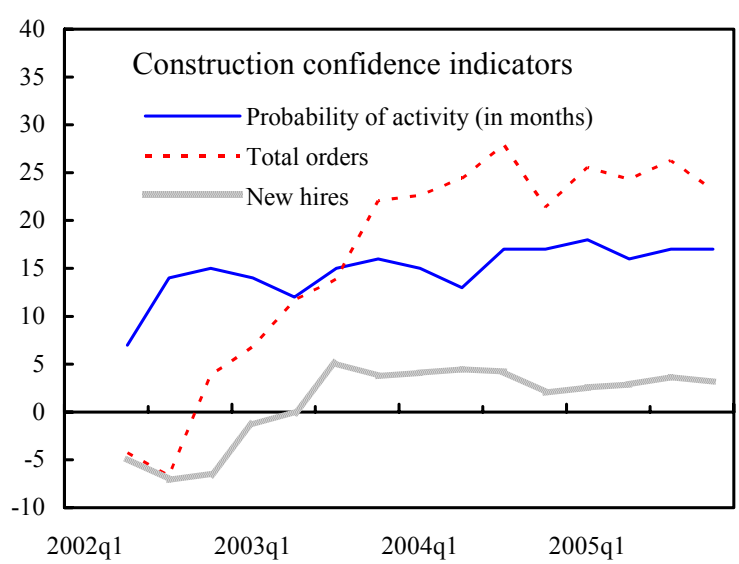

... despite a slowdown of domestic demand.

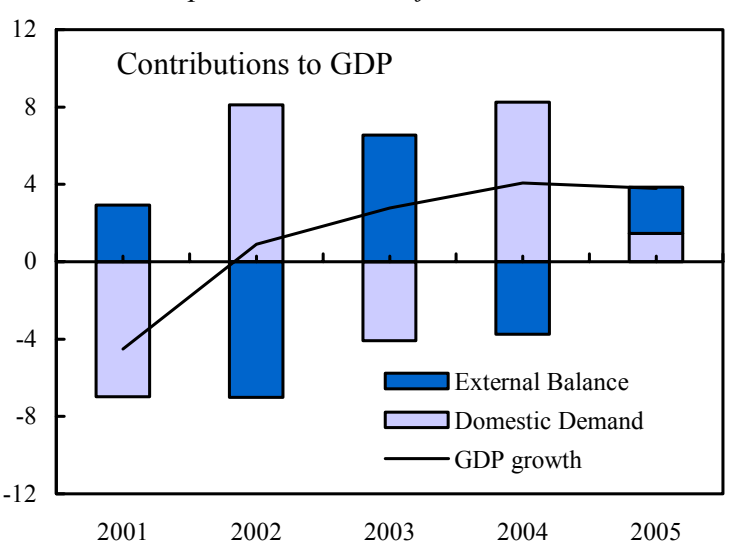

... manufacturing confidence remains strong...

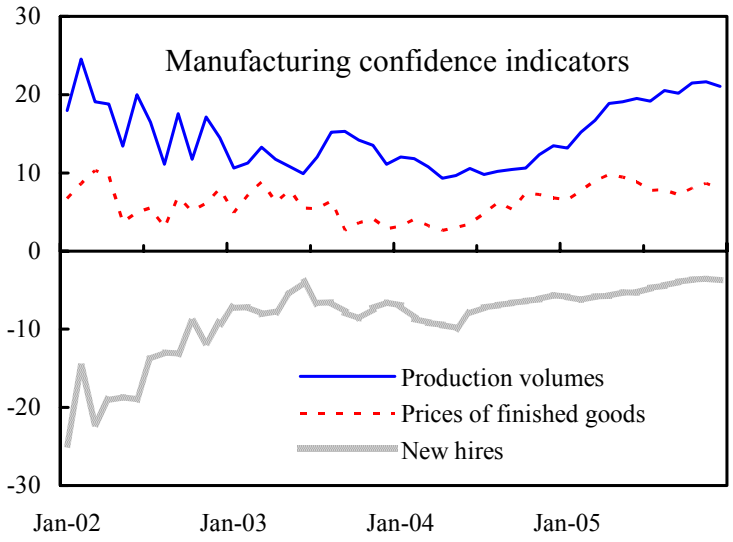

... which is reflected in the recent rise in employment.

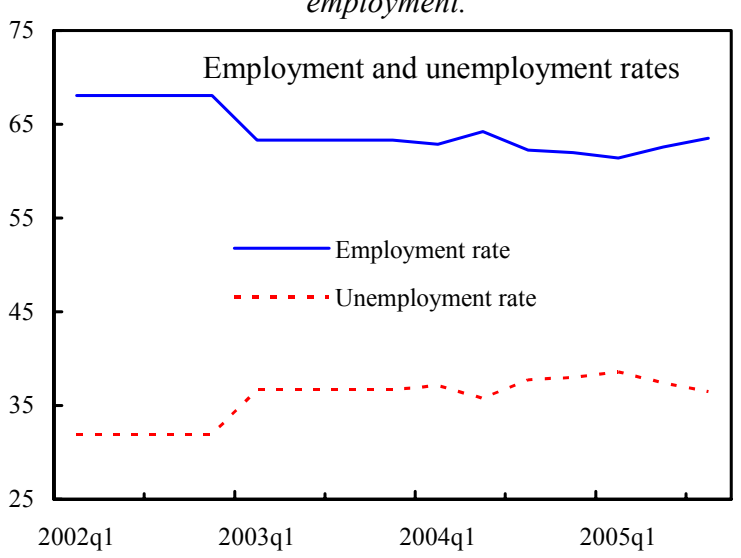

Sources: State Statistical Office; NBRM and IMF staff estimates. 
2. The reported current account deficit fell sharply to 1.4 percent of GDP, low by both regional and historical standards (Figure 2, Table 2). Although higher oil prices raised the import bill by 3.3 percent of GDP, the non-oil trade balance improved by more, with strong export performance in all sectors, particularly steel due to the reopening of a large factory, and lower growth of consumption goods imports. However, much of the current account improvement comes from cash transactions at foreign currency bureaus; aside from being volatile, part of these may properly belong to the capital account (Box 1).
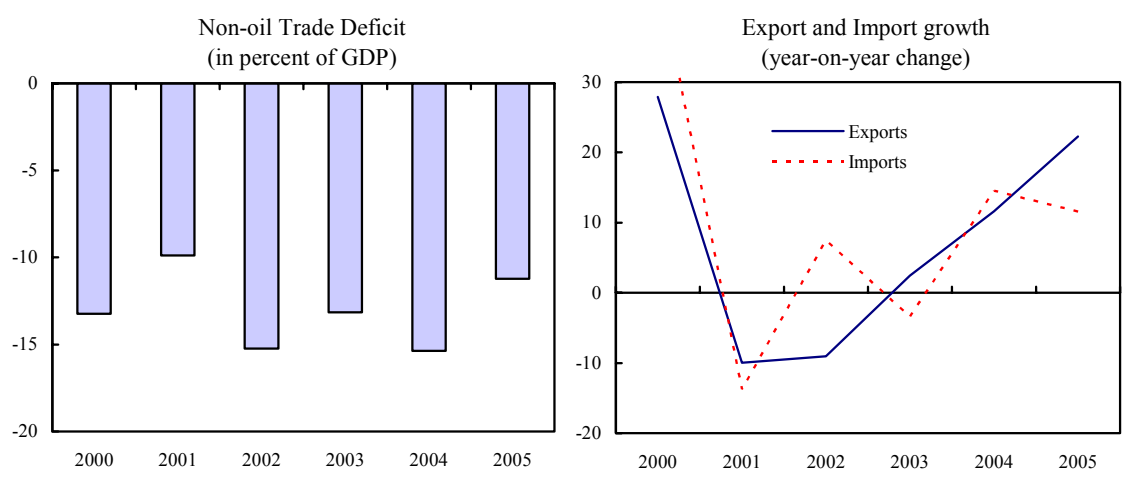

\section{Tight fiscal policy has contributed to the current account improvement}

(Table 3). The central government's 0.3 percent of GDP surplus surpassed the program target by more than 1 percent of GDP. Revenues fell short by $1 \frac{1}{2}$ percent of GDP, with shortfalls in grants, Special Revenue Accounts (SRA), and social insurance collections. However, spending undershot by even more, due to under-execution of SRA spending, curbs on public employment and procurement delays. Though core central government arrears are under control, Health Insurance Fund (HIF) arrears increased by 0.1 percent of GDP during the year.

\section{Both financial market confidence and the capital account seem to be improving} (Figure 3). Last year's $€ 150$ million Eurobond-FYR Macedonia's first-was four times oversubscribed, and followed a rating upgrade from Standard and Poor's to BB+, one notch below investment grade. With lower government funding needs and high demand for domestic paper, treasury yields have fallen. On the capital account, long-term private borrowing and portfolio flows have increased, while banks are finally starting to draw down their deposits abroad to lend domestically. Confidence should increase further if last December's European Council decision to grant EU candidate status leads to accession negotiations (Appendix I). However FDI remains weak, especially when compared to the

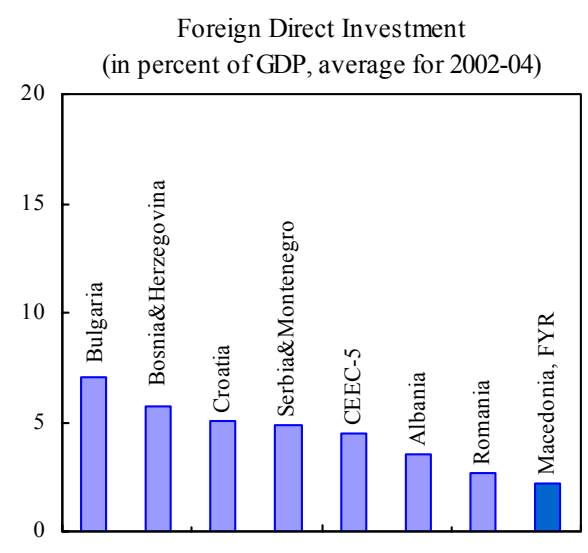
region and other EU candidate countries, suggesting serious business climate deficiencies. 
Figure 2. FYR Macedonia: External Sector Indicators, 2000-06

Buoyant private transfers sharply narrowed the current account deficit...

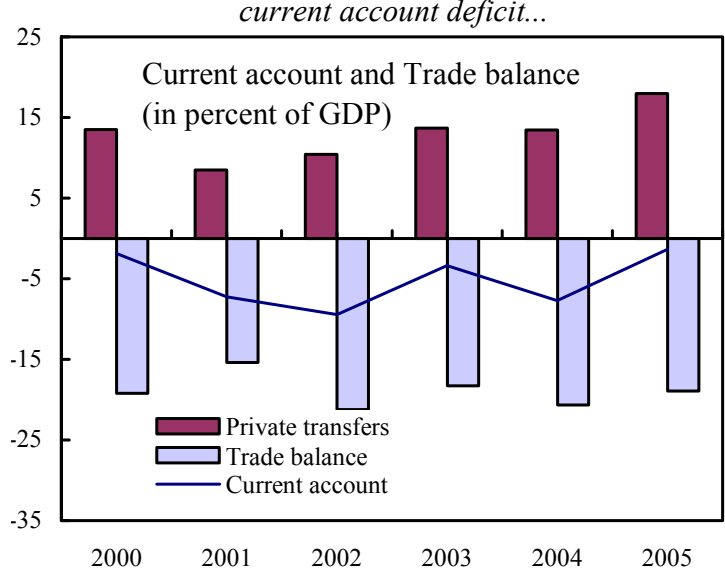

The Eurobond issuance boosted capital inflows to the public sector...

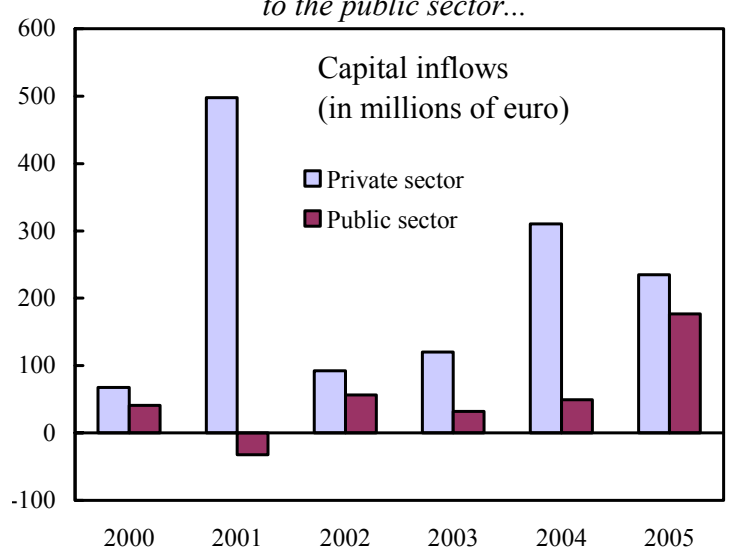

Reserves increased substantially...

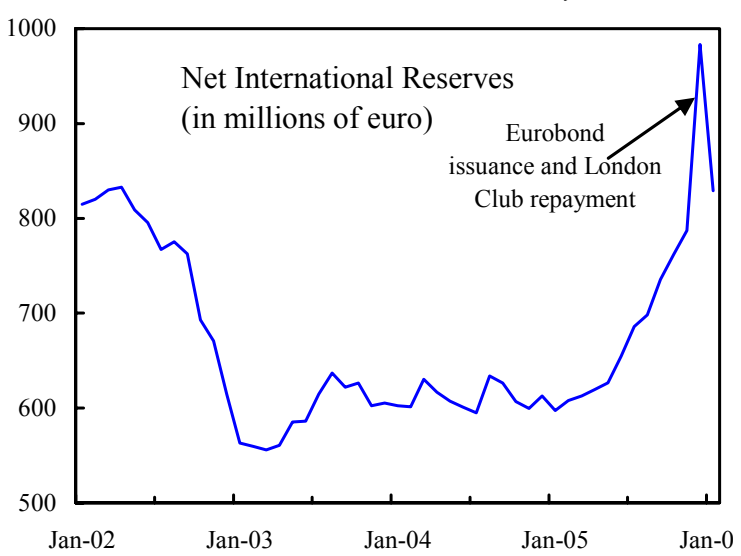

Sources: State Statistical Office and NBRM.
... which is low compared to other countries in the region.

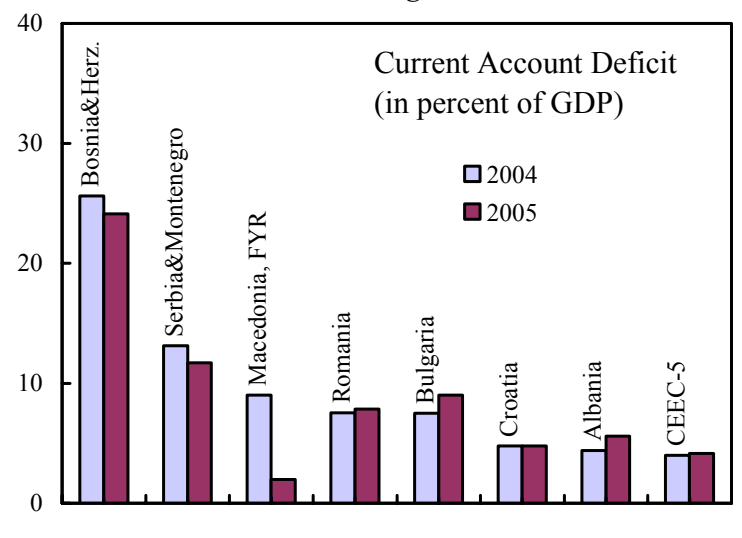

... but the external debt ratio remained stable.

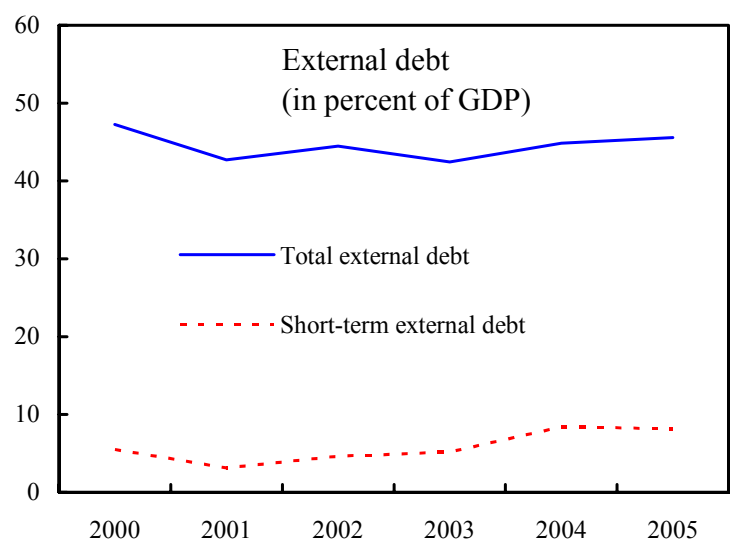

... and, unlike in the past, the NBRM was easily able to purchase foreign exchange.

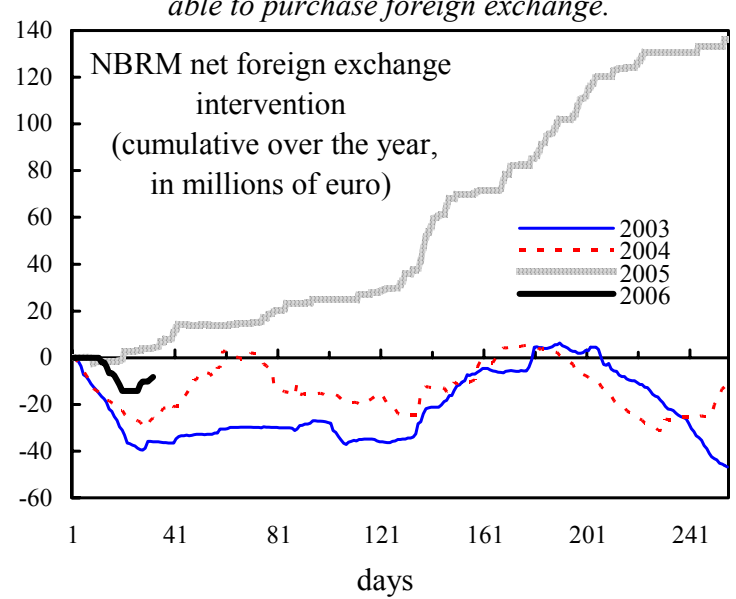


Figure 3. FYR Macedonia: Financial Market Developments, 2004-06

Demand for denar assets has been strong...

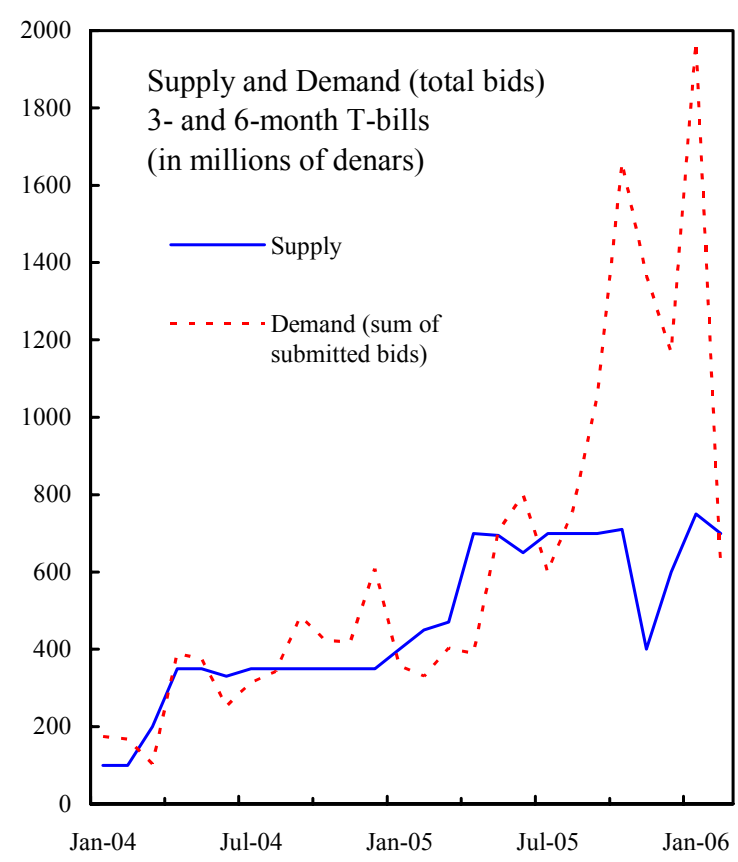

Interest rates have fallen in the light of strong

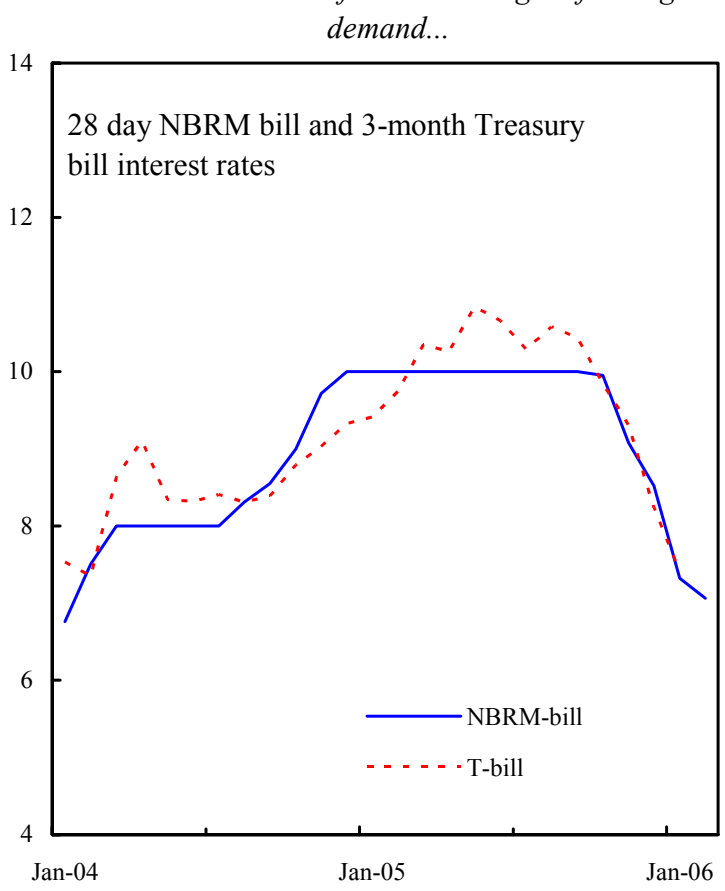

Sources: NBRM and IMF staff estimates.
... while the stock of central bank and treasury bills has increased.

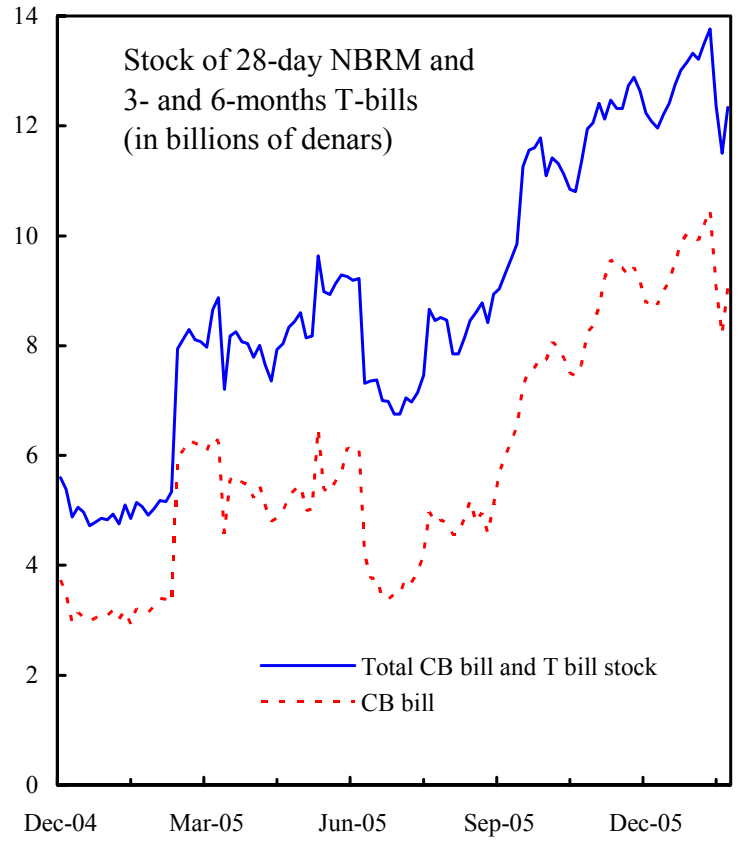

... and the stock exchange index has risen sharply, though mainly at the start of 2005.

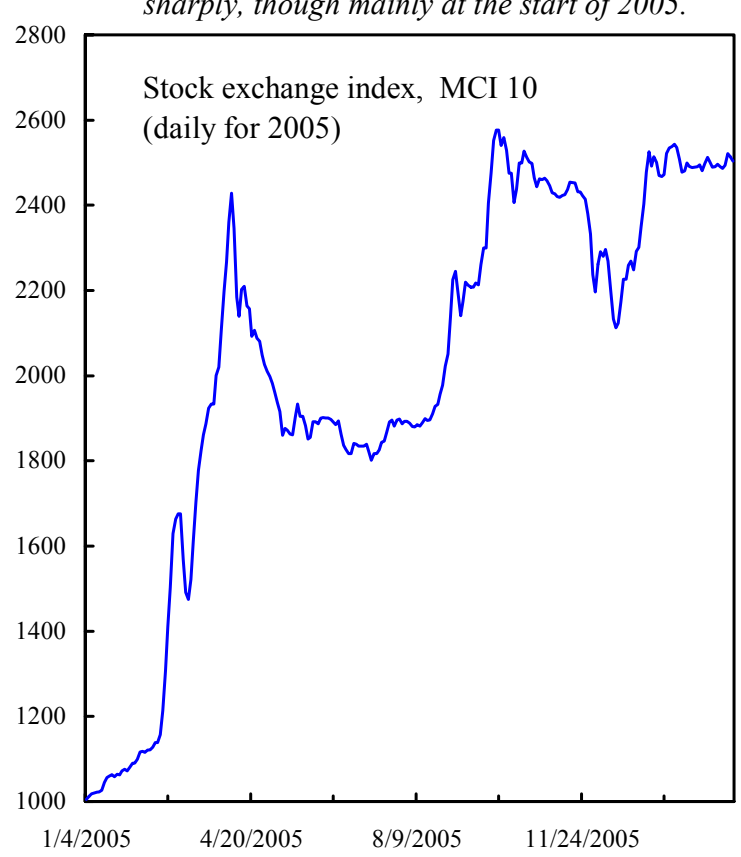




\section{Box 1. A Surge in Private Transfers?}

Although data compilation methods vary across countries, private transfers in FYR Macedonia are among the highest in the region - and grew rapidly in 2005. The increase in private transfers is explained by the increase in the foreign currency cash conversion, particularly that exchanged in bureaus, which is accelerating.
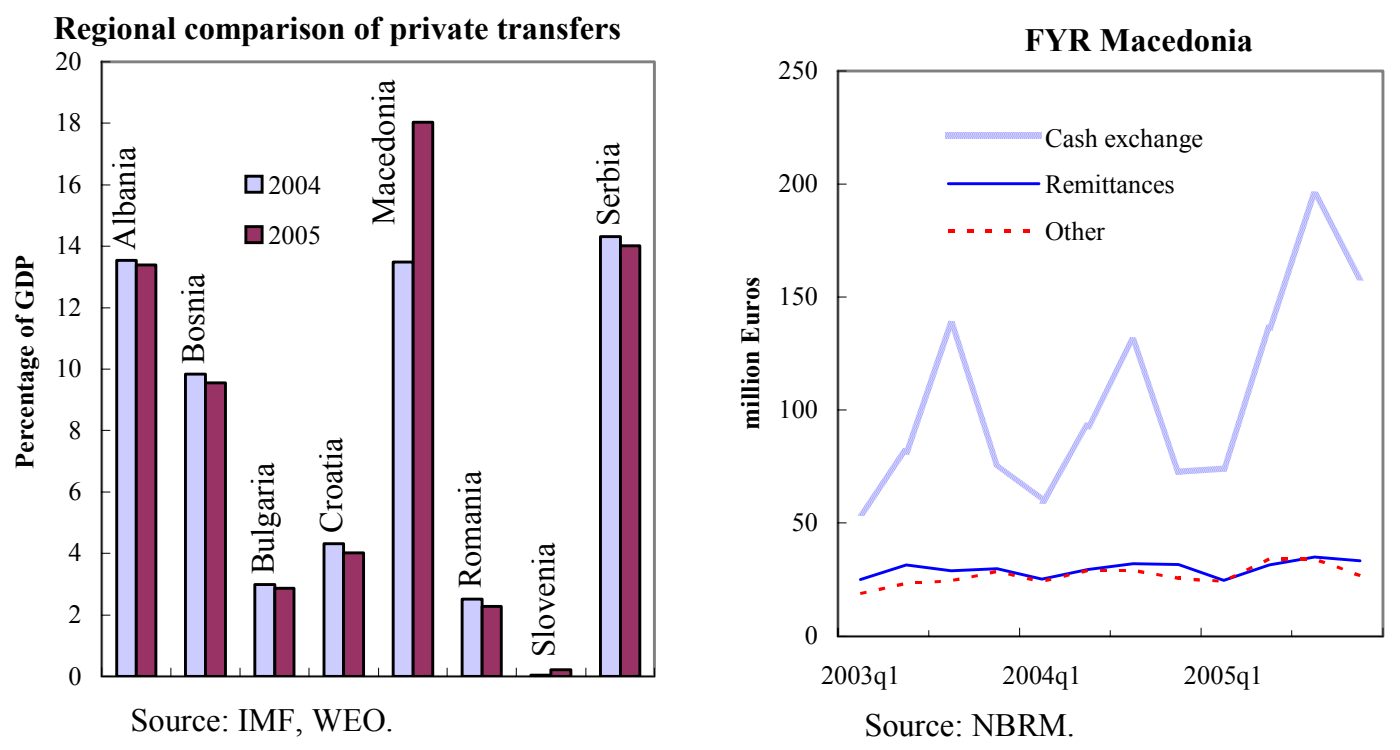

In FYR Macedonia such transactions are recorded in the current account since the authorities consider that cash exchange reflects transfers from migrants. However, this seems unlikely to explain the sharp increase in 2005. Without household survey data it is difficult to estimate how much of cash exchanged is truly a private transfer. Assuming that the migrant transfer component of cash exchanged in bureaus grew in line with "true" remittances (which is measured separately), total private transfers would be only 14 percent of GDP. The current account deficit in 2005 could then be as high as 4.4 percent of GDP instead of the 1.4 percent estimated.

In some sense, this calculation is conservative since it assumes all other cash exchanged is capital account: if it is informal economy trade, it should also appear in the current account. Against this, it does assume that past cash exchange transactions have been properly treated as current account.

The large increase in foreign currency exchanged might also reflect unrecorded portfolio investment or cash FDI. Alternatively, increased confidence in the denar may have prompted residents to switch their savings from foreign exchange to denars. Ahead of the Euro conversion roughly $€ 1$ billion worth of DM was converted into other currencies; however, according to balance of payments data, only half of this has been deposited in the banking system by individuals. 
5. The balance of payments is much stronger than programmed, NIR exceeding the end-2005 target by $€ 150$ million (3.3 percent of GDP). The central bank sterilized roughly half of the NIR increase through selling bills. In view of stronger international reserves and the costs of sterilizing these, but also the large output gap and weak price pressures, the NBRM lowered interest rates from 10 percent in November to 7 percent by end-January.

6. Though all monetary targets were met in 2005 , recent interest rate reductions and incomplete sterilization of last year's inflows are set to translate into stronger money and credit growth (Figure 4, Tables 4-5):

- $\quad$ Financial deepening is slowly increasing, with broad money rising to close to 40 percent of GDP. Denar deposits returned to their long term upward trend after falling in mid-2005 with payment overseas of the extraordinary telecom dividend. However, the share of foreign currency deposits is high at around 50 percent.

- $\quad$ Private credit growth remains strong, but bank profitability remains weak. Banks have rapidly expanded lending, to households and in foreign currency especially, though from a low base. Nonetheless bank capitalization, on average, remains sound although operating expenses absorb much of gross income. Though falling, almost 15 percent of loans are nonperforming (but fully provisioned for); nonproductive assets (fixed and foreclosed assets) equal half bank capital, in a few banks even higher.

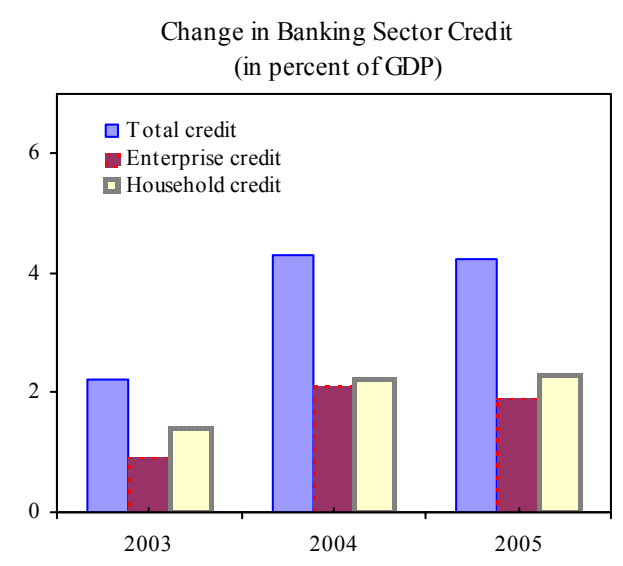

II. Policy Discussions

7. The key challenge is to translate this achievement of macroeconomic stability into sustained and rapid growth. Within the region, FYR Macedonia is often seen as a slower growing and less dynamic economy. Structural reform, backed by a stable economic environment, is the best way to overcome this. Already in the first six months of the program, albeit in some cases with delay, the authorities have completed nine of the ten endDecember structural benchmarks and three of the four structural performance criteria (LOI Table 2). Financial reporting of public health care institutions (HCIs) has been enhanced, a new one-stop shop for company registration

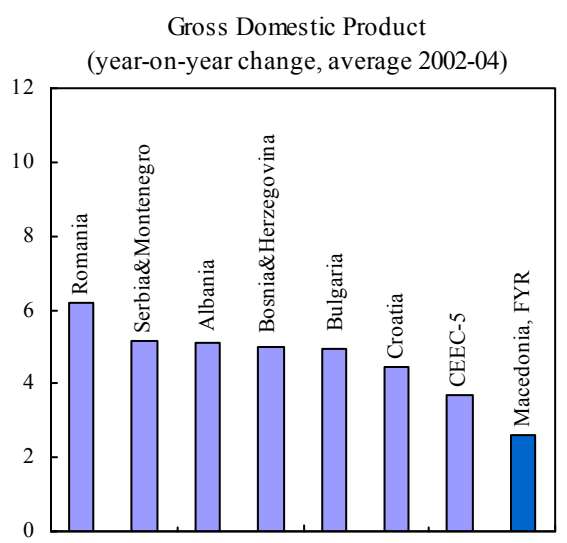


Figure 4. FYR Macedonia: Money and Credit Developments, 2001-06

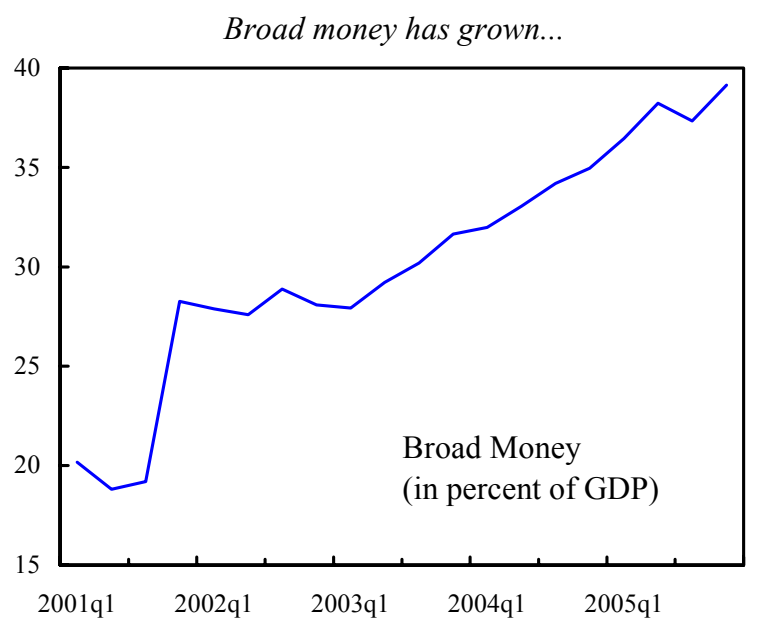

Both denar and foreign currency credit are increasing..

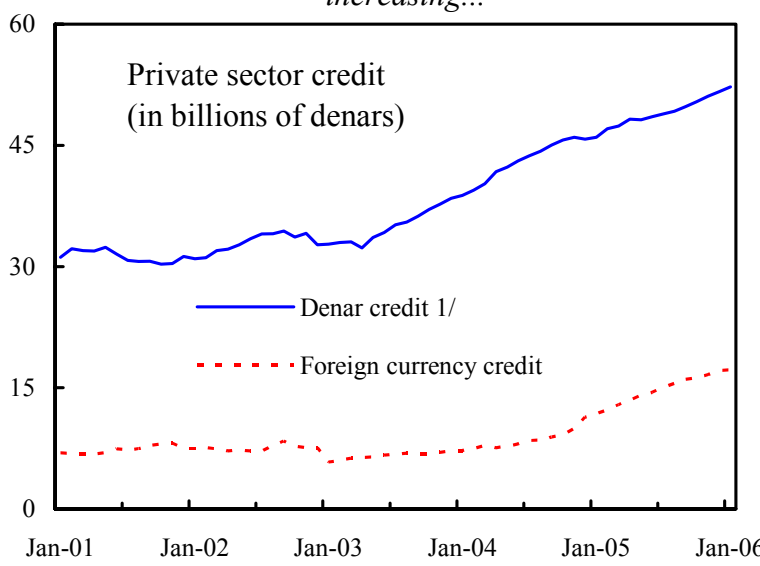

Falling interest rates should lead to more robust credit growth in $2006 .$.

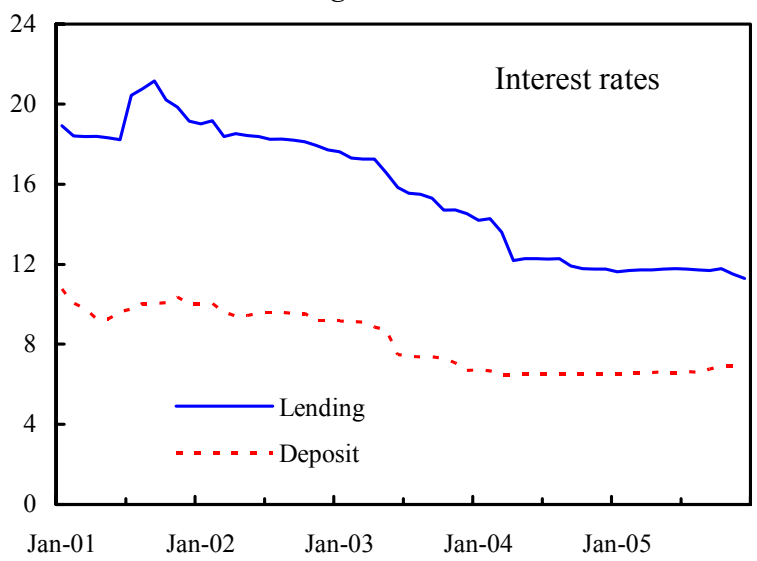

... with the share of denar deposits in broad money trending upwards.

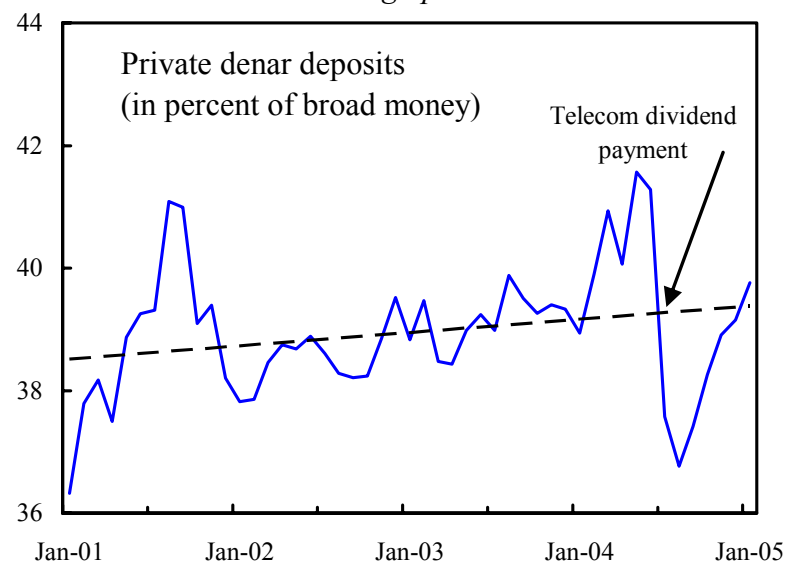

... with foreign currency lending growing particularly rapidly.

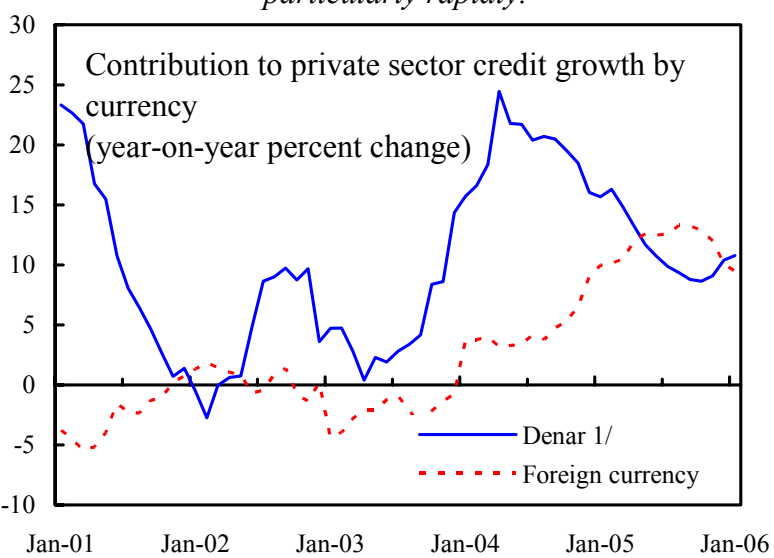

... which banks have financed by drawing down deposits held overseas.

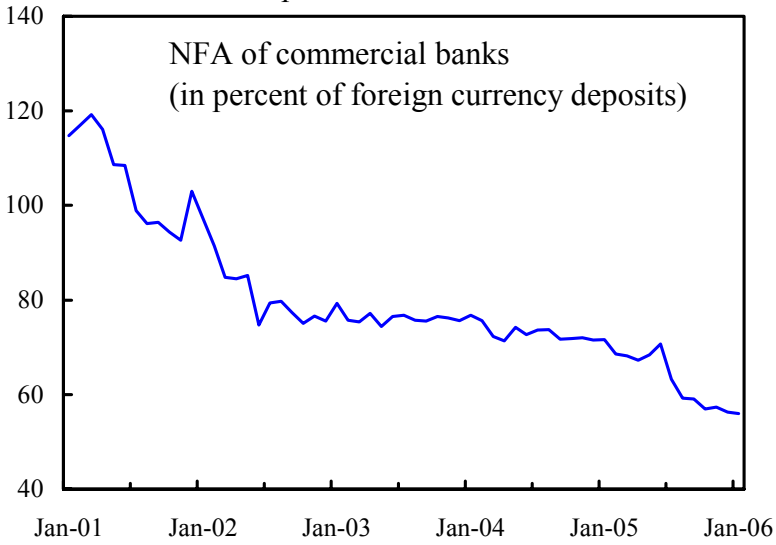

Sources: NBRM and IMF staff estimates.

1 / Includes foreign currency indexed lending (approximately one third of total denar credit). 
(consistent with EU requirements) was introduced, and Parliament passed a new bankruptcy law. Even so, business environment indicators and low levels of foreign direct investment suggest considerable structural reforms are still needed for rapid growth to be sustained.

8. In response, the authorities have decided to keep to the program's original 0.6 percent of GDP deficit target for 2006, while locking in most of the overperformance on international reserves. With growth and inflation on track, public spending under control, and the balance of payments and financing conditions considerably stronger (though admittedly with uncertainties over the full extent of the current account improvement), the modest fiscal easing is appropriate. The easing is also aimed mainly at the redirection of savings from public to private pensions (which would have little demand effect) and trade liberalization (Table 3). The authorities agreed to lock in two-thirds of the end-2005 reserve overperformance to protect the program from excessive monetary expansion. However, this will still allow some room to cautiously relax monetary policy in order to accommodate last year's increase in money demand and strengthen economic recovery in 2006.

9. To help sustain growth, the authorities are accompanying this slight relaxation of macroeconomic policies with further structural reforms, key to the program strategy. On top of existing structural conditionality, the authorities made new commitments to strengthen banking supervision (in light of rapid credit growth), to improve financial controls in the health sector (to address governance problems and to reduce arrears), to liberalize the telecommunications sector (a significant barrier to trade), and to abolish unnecessary licensing requirements. In addition, the authorities have established new timetables for telecoms privatization and for harmonizing tax and social contribution bases as part of their tax administration reform. LOI Table 2 summarizes the reform strategy.

\section{A. Macroeconomic Framework}

10. The macroeconomic framework is essentially unchanged from that laid out in the budget ( $(77):^{1}$

- Growth is conservatively projected at around 4 percent. With inflows pushing interest rates and lending rates lower, domestic demand should drive growth. While the authorities emphasized the impact on investment, staff cautioned that weak enterprise balance sheets could limit this, as opposed to consumer lending where growth was set to continue. Higher employment should also strengthen consumer confidence.

- Inflation is projected to increase to around 2 percent, but because of changes in administered prices and taxes, not growing demand pressures. Electricity price

\footnotetext{
${ }^{1}$ Numbers refer to LOI paragraphs.
} 
increases and higher tobacco taxes should raise consumer prices by $1 \frac{1 / 2}{2}$ percent. The authorities stressed that the high unemployment rate and the fixed exchange rate would help to restrain inflation.

\section{The current account deficit is projected to widen to around 4 percent of GDP} in 2006 while capital flows (excluding privatization and debt prepayment) stabilize. Slower export growth, higher domestic demand and the full year oil price effect are expected to raise the current account deficit by 3 percentage points, back towards the original (sustainable) program path.

12. Despite strong export growth in almost all sectors and the reduction in the nonoil trade deficit, competitiveness is still an issue (Box 2). In the past, large and persistent trade deficits and declining world export market share pointed to possible competitiveness problems. The authorities argued that this reflected a lack of dynamism in the manufacturing sector, operating in an economic environment that hampers private investment and where technology transfer through FDI has been limited. Sectoral data suggests that this may reflect patterns of specialization:

Macedonian exports have been concentrated in sectors whose world market shares are declining (Box 2). The authorities reaffirmed their belief that the current exchange rate regime had worked well, pointing to recent real exchange rate

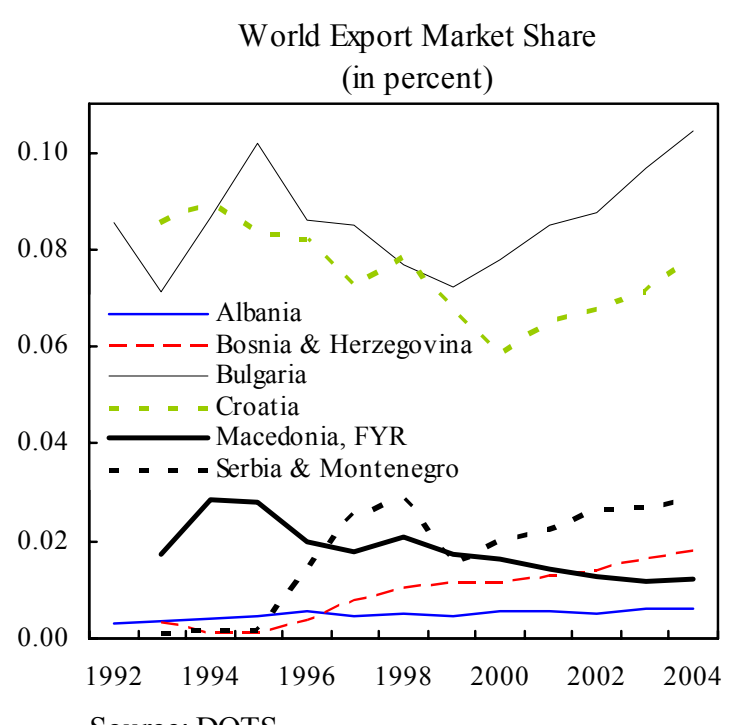

Source: DOTS. depreciation, the improvement in the current account, and the effectiveness of its nominal anchor role (Figure 5). Structural reform, for example last summer's labor legislation, and measures to improve the business environment were the best ways to improve competitiveness. These issues will be discussed more fully in the forthcoming Article IV consultation.

\section{B. Monetary Policy}

\section{Before adjusting rates again, the NBRM wanted to gauge the effects of last} year's interest rate cuts on domestic demand and the current account ( $(\mathbf{8 )})$. The largest banks had already lowered lending rates in response to last year's rate cuts; other banks were likely to follow. With credit growth projected to increase to about 23 percent this year, from 20 percent in 2005, the NBRM intended to keep rates on hold while it assessed the impact on credit and money growth. 


\section{Box 2. Export Performance, 1995-2004}

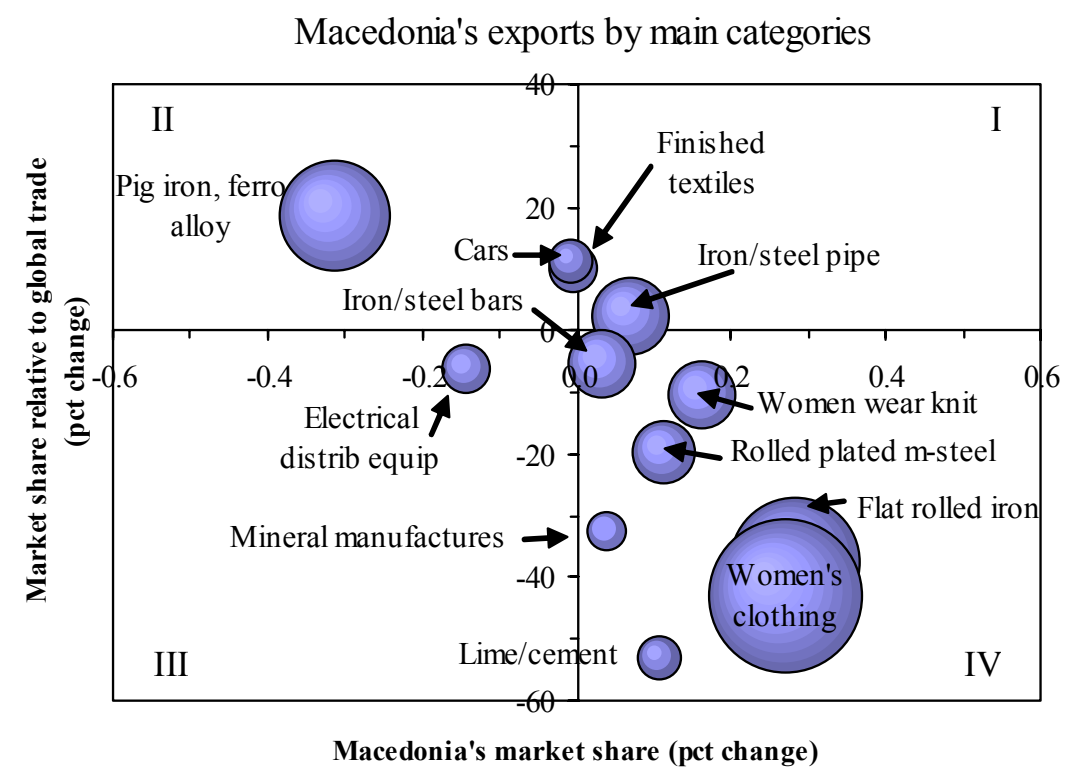

Detailed analysis of Macedonian manufacturing exports suggests that competitiveness problems may reflect specialization patterns.

Using export data from the Comtrade database, we looked at the evolution of the share of Macedonian exports in world exports from 1995 to 2004. Macedonian export share increased in those sectors in the right hand quadrants.

We compared this to the evolution of these sectors' shares in world manufacturing exports. The sectors in the two bottom half quadrants are those whose share in total world manufacturing exports have declined.

The graph indicates that Macedonian exports have increased most in the manufacturing sectors where the economy is specialized (measured by the size of the bubble), such as textiles, clothing, iron and steel. However, these sectors are losing share in world manufacturing trade, explaining why FYR Macedonia's share of total world exports has fallen. Low FDI levels compared to the rest of the region, partly due to shortcomings in the business environment, may also explain this pattern of specialization in non-dynamic sectors. 
Figure 5. FYR Macedonia: Exchange Rate Indicators, 2000-05

$$
(2000 \mathrm{q} 1=100) 1 /
$$
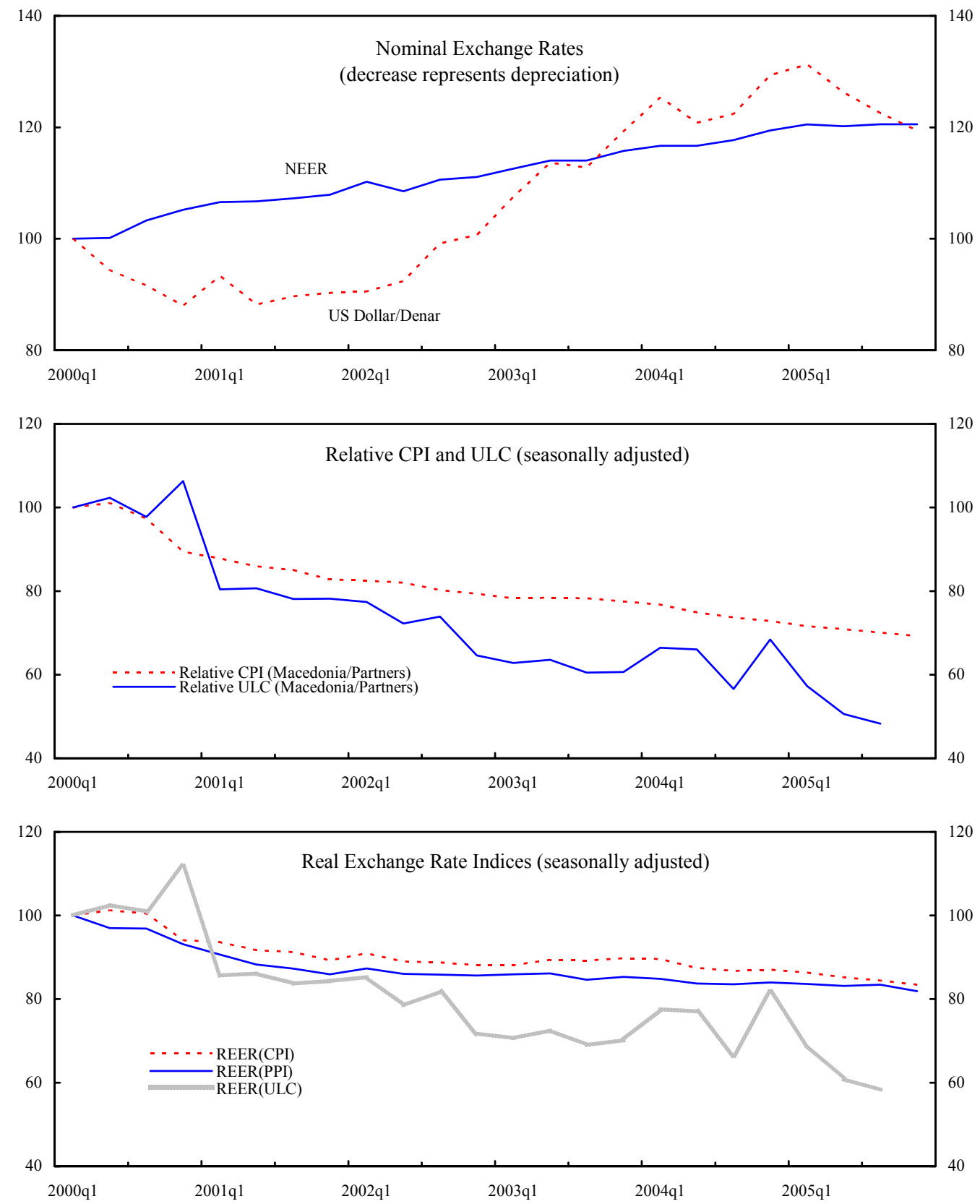

Sources: Eurostat; IFS; and IMF staff calculations.

1/ Deviations from past REER(ULC) indicators can be explained by revisions of trade weights (based on 19992001 data for exports and imports of goods; partner countries comprise Austria, Bulgaria, Croatia, France, Germany, Greece, Italy, Netherlands, Russia, Serbia and Montenegro, Slovenia, Switzerland, Turkey, United Kingdom, and United States), new data that allowed staff to base the ULC analysis on the manufacturing sector for all partner countries, and changes in the methodology that make the REER(ULC) fully consistent with that used for the REER(CPI) and REER(PPI). 
14. The NBRM agreed to revise the 2006 NIR and NDA targets in light of last year's increase in money demand, to prevent excess monetary expansion ( $\mid 16-17)$. With strong overperformance to date and a fairly conservative inflow projection for 2006, the original program targets allow too much room for monetary expansion. Though receipts from the 2005 eurobond were used to pay off London club debt ( $€ 120$ million), privatization receipts and continued strong performance of transfers suggest that reserves could increase above the original program targets. To prevent this from leading to excessive monetary expansion, the authorities and staff agreed to tighten the end-year targets by $€ 100$ million, two-thirds of the end-2005 overperformance, while at the same time increasing the privatization adjuster by $€ 50$ million to reflect uncertainties over timing and size of receipts. However, the staff cautioned that the reserve increase could be higher than the revised program, in which case monetary control might require more sterilization. The issuance of treasury bills for monetary policy purposes (structural benchmark) would help here, as would the NBRM's commitment to maintain its prudent monetary policy if reserve overperformance continued ( $₫ 8)$.

\section{Fiscal Policy and Reforms}

15. The 2006 budget targets an overall deficit of 0.6 percent of GDP, a widening of almost 1 percent of GDP from 2005, in line with the program (ब99):

- $\quad$ Revenues relative to GDP are projected to fall by 1.4 percentage points. Tax revenues fall by 1 percent of GDP from 2005, as part of the social security contributions move to new private pension accounts, and import duties decline with trade liberalization. Non-tax and capital revenues and grants are projected to fall by 0.4 percent of GDP because of last year's extraordinary telecom dividend.

- Expenditures relative to GDP are projected to fall by $1 / 2$ percentage point. Wage growth is contained, while decentralization lowers central government spending on goods and services. Transfers are projected to fall by 0.4 percent of GDP as real pensions decline (in line with the existing formula) and welfare program targeting improves. Capital expenditures increase by 0.2 percent of GDP.

- Though representing a slight loosening compared to the 2005 outcome, staff viewed the deficit target as appropriate. Last year's surplus was exceptional, driven by one-off factors such as the telecom dividend and delays in public investment. Given the improvement in the current account and low government debt ratios, staff agreed that it was appropriate for the authorities to stick to the fiscal consolidation path agreed in the program, while being ready to adjust policies later if necessary.

16. The staff regretted the authorities' ad-hoc resort to tobacco tax increases to finance new spending. Tobacco taxes were raised early this year to finance tobacco farmer subsidies and the health sector, on top of the increases already in the budget. This would increase cigarette prices by more than 30 percent. The staff expressed concern at the 
accommodation of spending pressures outside the budget cycle, cautioning that the substantial price increase would encourage smuggling. In response, the authorities argued that tobacco taxes were below EU levels and health concerns justified an increase. To limit earmarking, they also pledged that money would be transferred to the health sector only if indirect revenues exceed budget projections, and would be used to pay for existing underfunded national health programs (which would help clear arrears).

\section{The authorities agreed to monitor the costs of the second pillar pension system,} introduced this year, in case offsetting measures were later needed. Higher than anticipated take up of the second pillar (private) pension scheme will reduce social insurance contributions to the government, creating a 0.3 percent of GDP pensions deficit in 2006. However, this reallocation of savings should not increase domestic demand, and the reduction in future obligations will lower future pensions deficits, improving government solvency. Given the authorities' record of fiscal overperformance, and with revenues likely to be higher (the budget estimates both the telecom dividend and new tobacco tax conservatively), the staff agreed that it would be premature to require offsetting fiscal measures now. Nevertheless, the authorities reiterated their commitment to meeting the program's deficit target and to including any necessary measures in a supplementary budget

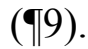

18. The staff welcomed progress in reforming tax administration ( $(13)$. Despite the delay in filling senior positions, reform is well on track: the organizational structure has been changed (in line with FAD recommendations) to improve registration, enforcement and audit; the law on tax administration will become effective in April 2006; and preparations for the large taxpayer unit (due by end-July) are almost complete.

\section{The authorities plan to harmonize the base for personal income tax and social} contributions in two phases, reflected in program conditionality (q13). Full harmonization is central to the tax administration reform, and will require abolishing the presumptive minimum salary base for social contributions. Given limited capacity to audit wages, the government argued for a two-step approach: starting January 1, 2007, the social contribution bases (which vary tremendously across sectors, representing considerable crosssubsidization) would be harmonized and simplified (a performance criterion will be set at the Second Review); social contribution and personal income tax harmonization would start January 1, 2008 (a performance criterion will be set once the details of the strategy are agreed). Staff agreed that the phased approach was the best way forward given capacity constraints, but emphasized the need to merge social contribution and personal income tax collection within the PRO, a key long-term goal.

20. Health sector finances have worsened since end-2004 ( $₫ 10)$. The Health Ministry presented the mission with new figures on HIF arrears. The picture is mixed (Appendix II). Using the program definition (more than 60 days overdue), arrears were previously overstated and fell in the last quarter of 2005; even so, they are above end-2004 levels, breaching the program's performance criterion. Broader measures of health sector debts and 
arrears are also declining, with overall debts below their end-2004 level. However, precise numbers on arrears are difficult to verify.

21. On balance, improvements in health finances towards the end of 2005 suggest the program's reforms may be working:

- In line with World Bank guidance, in 2005 the HIF introduced competitive international tendering for drugs on the positive list, saving 0.2 percent of GDP. The HIF is also tightening access to sick and maternity leave, which have been abused in the past, though extending responsibility for sick leave payments may partly offset the cost savings. The authorities are taking additional steps to control health finances (\$11), including placing new budget officers in each of the top 15 public health institutions and in the HIF (new structural benchmarks under the program). That said, these measures cannot be a substitute for fundamental health sector reform.

- The mission agreed with the authorities' request to convert the health arrears performance criterion to an indicative target, in light of these improved controls, the small size of health sector arrears measurable under the program $(0.4$ percent of GDP), and measurement difficulties. However, given the sector's high share in government spending and considerable governance problems, staff will continue to work closely with the World Bank on health sector reform.

\section{Financial Sector Reform}

22. Bank ownership is highly concentrated and a large share of bank intermediation is denominated in foreign currency (Figure 6). There are 20 banks and 14 saving houses, roughly half under foreign ownership, for only 2 million people. Yet there is concentration too, with the three largest banks holding two-thirds of total assets. Half the assets and liabilities are foreign-currency denominated, mainly Euro. Inherited asset quality problems, high operating costs, low competition, weak credit culture, and an inefficient judicial system hamper bank intermediation.

23. The NBRM is trying to address the opaque ownership structure of some banks. Some small banks are "pocket banks" of enterprises or individuals, with significant governance problems, poor risk management, and continued operating losses. The NBRM also expressed concern at the ownership of some savings houses (mainly microfinance) by non-profit organizations, which might lack resources in case of capital shortfalls. 
Figure 6. FYR Macedonia: Banking Sector Developments, 2001-05
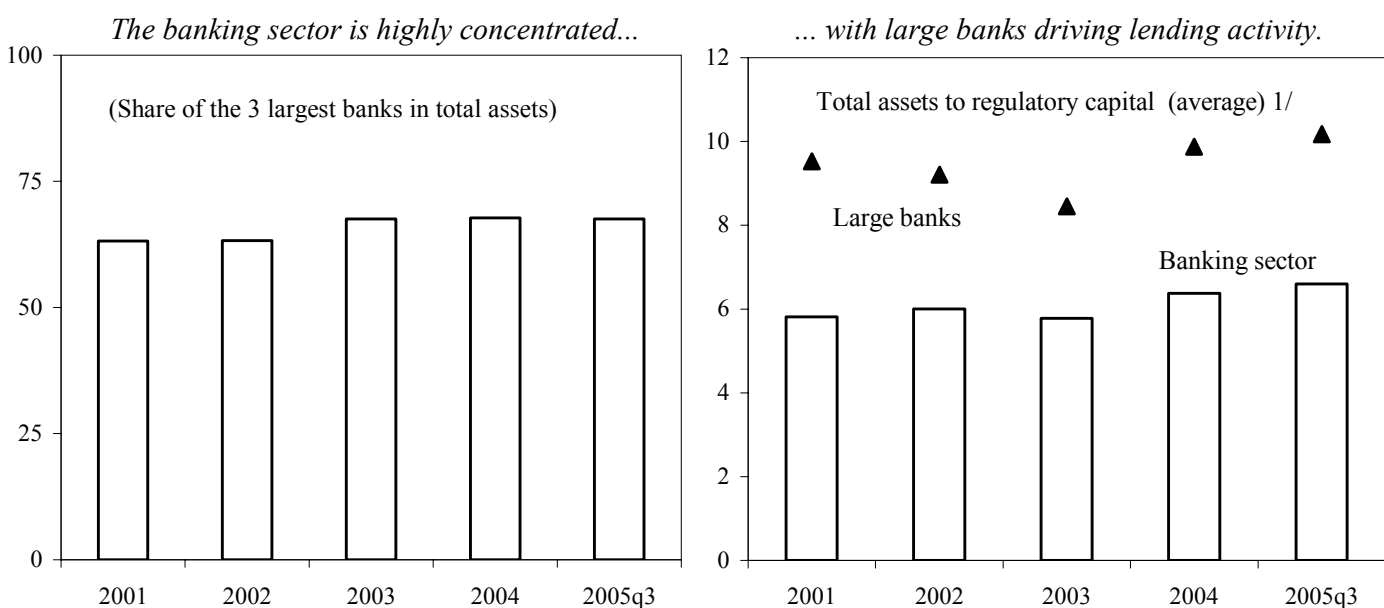

Although forex and forex-indexed lending has risen....

... the banking sector's risk profile has increased moderately.
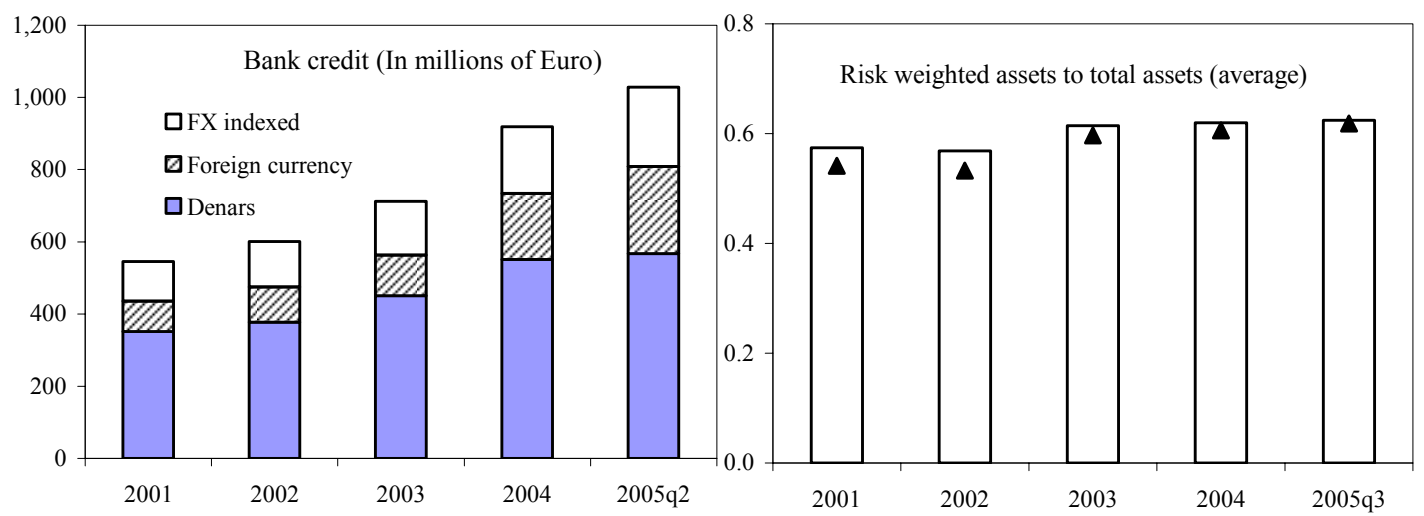

Interest margin remains the largest source of

... and operating costs absorb a large, albeit income...

declining share of gross income.

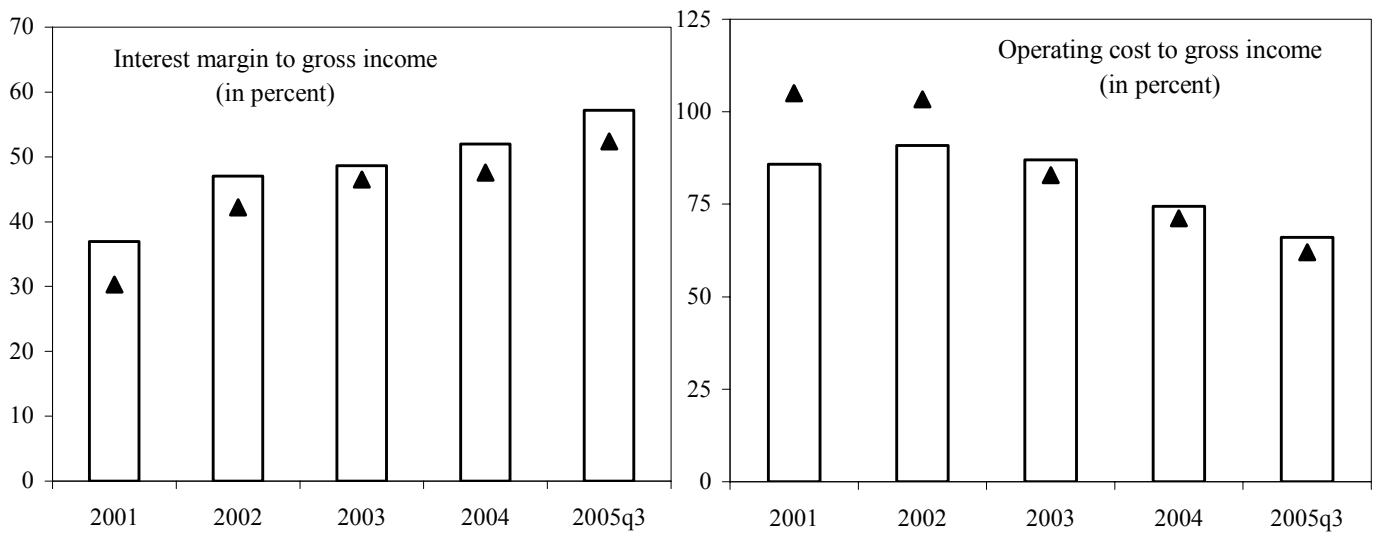

Source: NBRM; and Fund staff estimates.

$1 /$ Total assets include off-balance sheet items. 
24. Weak legislation and limited staff resources hinder bank supervision. The

NBRM must seek court approval before imposing fines, and courts have substantial powers to delay or even reverse remedial actions imposed by the NBRM, compromising supervision enforcement. The authorities agreed to seek passage of legislation (including NBRM Law amendments) to enhance the effectiveness of bank supervision, in part by reducing the appeals role of the NBRM Council ( $\mid 18)$. This would strengthen the governor's powers, while still leaving the right of court appeal for financial compensation. The forthcoming Law on Misdemeanors should also give the NBRM legal powers to impose administrative penalties.

25. The authorities are enhancing bank regulation and supervision, and will propose a comprehensive revision of the Banking Law:

- With rapid credit growth set to continue, the NBRM agreed to supplement the 15 on-site and 4 off-site supervisors with new staff ( $(120)$.

- In line with World Bank technical assistance recommendations, the NBRM has adopted a Supervisory Development Plan that shifts to risk-based supervision. It is finalizing prudential regulations reducing foreign exchange and market risk, and by end-June will issue new regulations requiring a gradual write-off of foreclosed assets and a mandatory general provision on normal loans (new structural benchmark) ( $\mid 21$ 22). An MFD-sponsored resident adviser will help the NBRM implement the SDP.

- The authorities have prepared a draft Banking Law that improves bank governance and licensing, and raises minimum capital requirements. However, in part because of prolonged consultation between the MOF and NBRM, this was not submitted to Parliament by the end-2005 deadline in the program (structural performance criterion). The staff noted areas which needed improvement, including bank resolution, connected lending, and consolidated supervision. The authorities are requesting Fund technical assistance so that a more comprehensive draft law can be agreed by September (new structural benchmark). Passage of the law by year-end will be set at the Second Review as a performance criterion (\$19).

\section{E. Structural Reform}

26. Though the authorities have made substantial progress in privatizing electricity distribution (ESM), the staff stressed the importance of strengthening regulation ( $(24)$. The electricity distribution company was sold to a strategic foreign investor in March for $€ 225$ million (almost 5 percent of GDP) in a transparent tender. Despite spending pressures prior to the elections, the authorities used the privatization proceeds to strengthen the NBRM's reserves. In January, the energy regulator approved separate tariffs for generation, transmission and distribution; however, tariffs for final consumers were left unchanged. The authorities argued this was because the state, as the current owner, did not request such an increase. The mission expressed concern that this may reflect weak independence of the regulator in the face of political pressure not to raise prices before the election. 
27. The mission stressed the importance of liberalizing the telecommunications sector, where lack of competition made services expensive:

South Eastern Europe: International Call Prices and Internet Usage

\begin{tabular}{lccr}
\hline & \multicolumn{2}{c}{$\begin{array}{c}\text { Cost of ten-minute call to land } \\
\text { line }\end{array}$} & $\begin{array}{c}\text { Internet users } \\
\text { in population } \\
\text { 3/ }\end{array}$ \\
\cline { 2 - 3 } & to the UK 1/ from World 2/ & (percent) \\
\hline FYR Macedonia & (in Euros) & 1.76 & 6.2 \\
Albania & 6.93 & 1.37 & 1.3 \\
Bosnia and Herzegovina & 4.34 & 1.65 & 15.1 \\
Bulgaria & 9.52 & 0.55 & 18.4 \\
Croatia & 1.84 & 0.43 & 32.2 \\
Romania & 3.58 & 1.01 & 9.5 \\
Serbia and Montenegro & 2.62 & 0.93 & 12.3 \\
Turkey & 3.32 & 1.11 & 14.2 \\
Regional average & 1.59 & 1.56 & 13.7 \\
\hline
\end{tabular}

Source: www.skype.com; Cullen International.

1/ Rates as offered by the incumbent fixed line providers. For Bosnia and Herzegovina, an average of prices offered by the three regional providers.

2/ Proxied by rates offered by the Skype internet telephony service.

3/ For Serbia and Montenegro, an average value of the estimates for each of the two republics, excluding Kosovo.

- $\quad$ The mission urged the government to implement the February 2005 Law on Electronic Communications to liberalize the market ( $(25)$. Fixed-line services are controlled by a monopolist, who also dominates the mobile market. Profits are around 2 percent of GDP, similar to customs revenues, and the high costs likewise impede trade. Implementation is a requirement under the EU Stabilization and Association Agreement, and is one of the five key priorities identified by the European Commission (Appendix I). Given the economic significance of this sector, the authorities agreed to include implementation of the Law in the program. However, since implementation itself is difficult to measure, the program will monitor quantitative improvements in liberalization and competition to assess progress.

- The mission encouraged the government to meet its program commitment and sell its remaining telephone company shares (\$24). Reducing state ownership should encourage liberalization, by breaking the government's dependence on the telecom dividend as revenue. However, the original sale agreement severely restricts the terms of any sale, giving the incumbent right of first refusal. Though the authorities reaffirmed their commitment to the sale (structural performance criterion), it may only be completed by end-December rather than the original end-June timetable. The mission stressed the need for maximum transparency in the sale. 
28. The authorities reaffirmed the importance they attach to judicial reform ( $\$ 27-$ 28). Constitutional amendments passed at end-2005 strengthened the independence and efficiency of the judiciary. Due to delays in staffing the Judicial Budget Council, the authorities were unable to provide an analysis of the fiscal costs of these reforms for the 2006 budget - missing a structural benchmark in the program. The authorities believed sufficient resources were available in the current court budget and from donors to cover start-up costs in 2006, and committed themselves to fully finance judicial reform in the 2007 budget.

Ease of Doing Business
(rank among 155 countries)

Number of Licensing Procedures for Businesses

\begin{tabular}{lrlr}
\hline Bulgaria & 62 & Slovenia & 14 \\
Slovenia & 63 & Romania & 15 \\
Romania & 78 & Bosnia and Herzegovina & 17 \\
Macedonia, FYR & 81 & Macedonia, FYR & 18 \\
Bosnia and Herzegovina & 87 & Serbia and Montenegro & 21 \\
Serbia and Montenegro & 92 & Bulgaria & 24 \\
Albania & 117 & Croatia & 28 \\
Croatia & 118 & European average & 21 \\
\hline
\end{tabular}

Source: World Bank, Doing Business Database

29. The authorities agreed that more was needed to improve the business

environment. Though the introduction of the one-stop shop for business registration had been a success, the business environment in general needs to be improved. On top of measures to improve governance already in the program, the authorities committed to identifying and removing unnecessary licensing requirements (\$29). The staff will revisit this issue for the Article IV.

\section{Program Modalities ANd Risks}

\section{Performance Criteria}

30. The attached Letter of Intent describes progress in implementing the program supported by the Stand-By Arrangement and requests completion of the First Review. In seeking completion of the First Review, the authorities request a number of waivers of nonobservance and applicability, and revisions to the program targets (Table 6; LOI Tables 1 and 2). Notwithstanding the unavailability of the information necessary to assess observance, the staff believes the program will be successfully implemented and there is no clear evidence that the performance criteria for which a waiver of applicability is sought will not be met.

31. Should additional resources available under the SBA need to be drawn, staff is confident that FYR Macedonia could continue meeting its obligations to the Fund. 
Stronger macroeconomic and balance of payments performance have reduced the minimal risks identified at program approval and improved the debt outlook (Tables 7-9). However, current account volatility, weaknesses in the composition of the balance of payments, and the need to smooth the debt service profile support the authorities' request to extend repurchases from an expectations to an obligations basis (equivalent to SDR 13,386,669; 96 ). The debtsustainability analysis will be updated in the coming Article IV consultation.

\section{Aside from political instability, main areas of program risk include this year's} election, possible delays in structural reform, and the impact of stronger domestic demand on the current account:

- $\quad$ Though the election may create spending pressures, the authorities have committed to resist this. However, privatization has become politically sensitive in the run-up to elections, which may cause delays.

- The program relies on ambitious structural reforms to generate growth. While the new government's commitment to reform and to the program cannot be known, all major political parties are committed to EU membership and this should augur well for continued reform.

- With interest rates falling consistent with the fixed exchange rate, and the fiscal deficit set to widen, the program projects an increase in domestic demand and a wider current account deficit. However, given past volatility, there is a risk that both of these might be larger than projected. Financing may also be weaker, to the extent the reported increase in transfers may really be short-term capital inflows.

- Finally, political risks are never far away: both internally with the coming election, and externally depending on developments in neighboring countries.

\section{Staff Appraisal}

33. Macroeconomic performance and prospects are strong. The recent record of steady growth with low inflation looks set to continue. Prudent financial policies have strengthened the balance of payments, somewhat easing the traditional external constraint to growth. EU candidacy has the potential to transform the economy further, and to put FYR Macedonia on a more rapid growth path.

\section{Though the NBRM's record of low inflation and monetary control is strong, it} needs to be ready for the challenge should capital inflows persist. The exchange rate has served FYR Macedonia well as a nominal anchor, and the recent improvement in the current account suggests that competitiveness concerns may be easing. Within this framework, the NBRM's policy of letting interest rates decline gradually while building up reserves has been appropriate. Profitability concerns should not inhibit sterilization, particularly if capital inflows were to take off. While an environment of buoyant foreign exchange flows would be 
something of a novelty for FYR Macedonia, monetary and fiscal policy should be ready to respond should these continue.

35. The $1 / 2$ percent of GDP fiscal deficit target remains appropriate. Though the introduction of subsidies to tobacco farmers was unfortunate, the authorities are to be commended for their commitment to increase funding of national health programs. However, these decisions should have been part of the budget. The staff welcomes the authorities' pledge to resist election-related spending pressures and to meet this year's deficit target. While fiscal discipline is appropriate for the short-term, the authorities need to improve their capacity to implement public investment projects. This is important both for the EU accession process and economic growth.

36. With macroeconomic fundamentals sound, the government needs to improve its mixed record in structural reform to sustain stronger growth. Aside from their economic benefits, substantial structural reforms are also needed for EU accession. Internal debate within the EU on enlargement makes early implementation of reform more important, to bolster the case for membership. This year's elections should not be allowed to delay reform.

37. Though arrears may be stabilizing, the authorities need to continue health sector reform. Annual budgeting and the introduction of competitive tendering have helped contain arrears. Additional steps outlined in the Letter of Intent should improve financial controls further. But financial controls alone are unlikely to solve the arrears problem. The staff therefore encourages the authorities to work closely with the World Bank on more fundamental reform of the health sector, such as reducing administrative staff and expanding tendering.

38. The three-year payroll tax administration reform appears to be going well. The PRO is implementing the Netherlands and IMF-supported reform program effectively, with creation of large taxpayer and large contribution offices on schedule. The staff welcomes the authorities' commitment to harmonize social security contributions. Since these vary tremendously across sectors, this is likely to be politically sensitive. The next step should be to harmonize these with personal income tax bases, in the context of a broader review of tax policy.

39. With credit growth set to accelerate, the staff welcomed the authorities' efforts to strengthen banking supervision. Reducing the review role of the NBRM Council and limiting the powers of the courts to overturn decisions should bolster bank supervision. The staff supports the authorities' plans for more comprehensive revision of the Banking Law, but urges the NBRM and MOF to cooperate more closely in these areas, to avoid a recurrence of delays. The commitment to increase the number of bank supervision staff should also complement these efforts.

40. Liberalization of communications is overdue. High telecommunications charges are a significant barrier to trade and ideas, increasing the country's economic isolation, and impeding economic development. The staff welcomes the authorities' new program 
commitment to liberalizing this sector, consistent with EU requirements. The government needs to eliminate its conflict of interest by selling its residual telecom shares as envisaged under the program.

\section{The staff commended the authorities on their success in privatizing electricity}

distribution. The international tender generated a transparent bidding process which resulted in strong privatization proceeds. The privatization should reduce enterprise subsidies and energy theft, and encourage infrastructure investment. A strong, effective, and independent regulator is needed, with tariff schedules set to protect low-income groups. The staff welcomes the Prime Minister's public commitment not to spend the proceeds from privatization ahead of the election.

42. Reform of the business environment needs to continue. The one-stop shop company registration system is commendable, as is the commitment to streamline business licensing. Judicial reform, including court organization and training of judges, is crucial and needs to be adequately funded. However, low levels of foreign direct investment point to more serious business environment problems, including poor governance, which need to be addressed if FYR Macedonia is to succeed in its attempts at EU accession.

43. In light of the authorities' strong macroeconomic performance and their commitment to structural reform, the staff recommends completion of the First Review. The economic reform program is strong. The authorities have delivered an impressive record of fiscal discipline and prudent monetary policy. The revised program locks in recent reserve accumulation, limits the scope for monetary expansion, strengthens central bank independence, controls health sector arrears, and promises to liberalize the telecoms sector. On this basis, the staff supports the authorities' requests to complete the First Review, for waivers of nonobservance and applicability for the performance criteria, and for an extension of repurchase expectations. 
Table 1. FYR Macedonia: Selected Economic Indicators, 2001-06

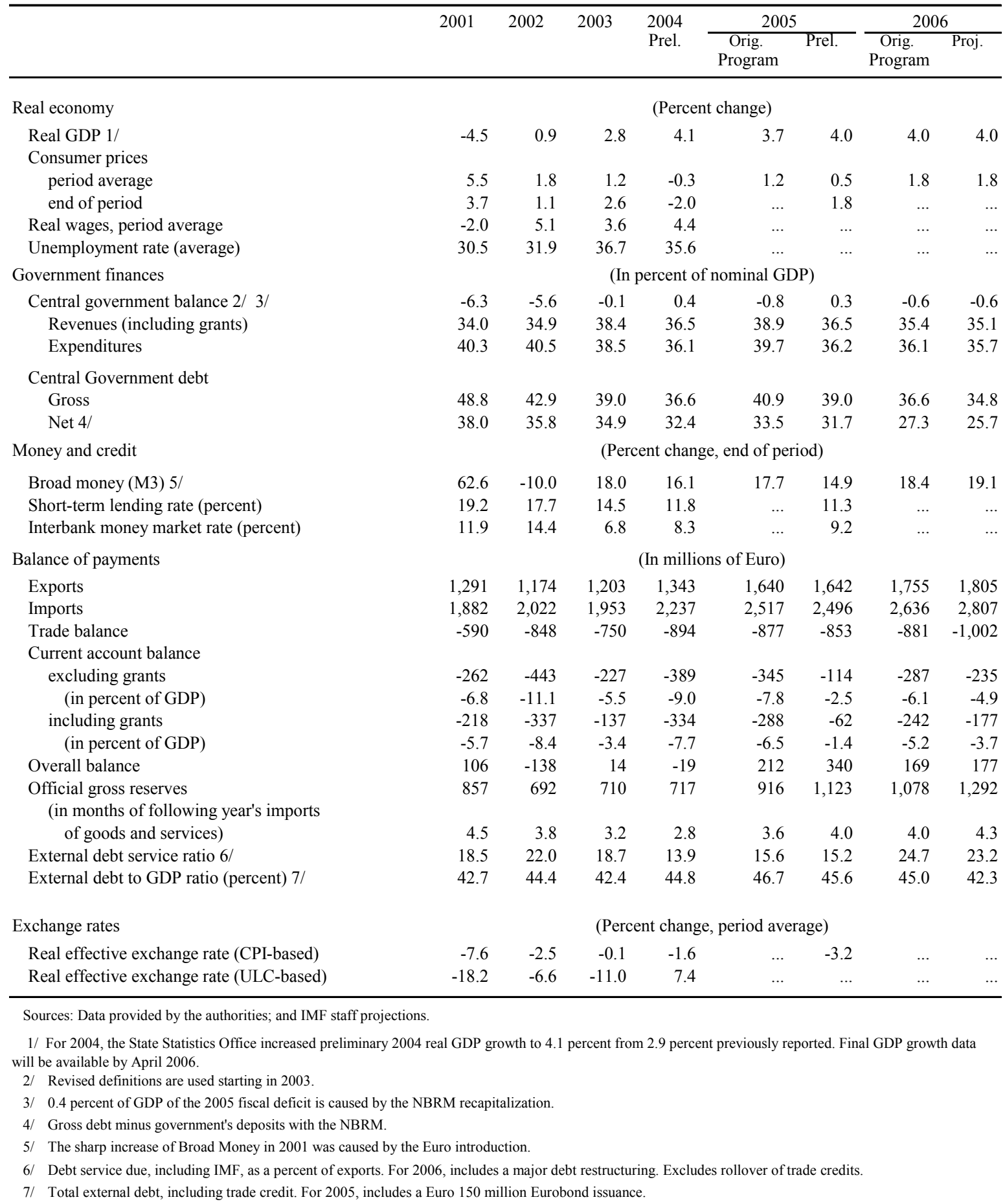


Table 2. FYR Macedonia: Medium Term Balance of Payments, 2003-10

(In millions of Euro)

\begin{tabular}{|c|c|c|c|c|c|c|c|c|c|c|}
\hline \multirow{3}{*}{ Current account } & \multirow{3}{*}{$\begin{array}{r}2003 \\
-137\end{array}$} & \multirow{3}{*}{$\begin{array}{r}2004 \\
\text { Prel. } \\
-334\end{array}$} & \multicolumn{2}{|c|}{2005} & \multicolumn{2}{|c|}{2006} & \multirow{2}{*}{$\begin{array}{l}2007 \\
\text { Proj. }\end{array}$} & \multirow{2}{*}{$\begin{array}{c}2008 \\
\text { Proj. }\end{array}$} & \multirow{2}{*}{$\begin{array}{c}2009 \\
\text { Proj. }\end{array}$} & \multirow{2}{*}{$\begin{array}{l}2010 \\
\text { Proj. }\end{array}$} \\
\hline & & & Program & Proj. & \multicolumn{2}{|l|}{ Program } & & & & \\
\hline & & & -288 & -62 & -242 & -177 & -220 & -227 & -223 & -219 \\
\hline Excluding official transfers & -227 & -389 & -345 & -114 & -287 & -235 & -280 & -280 & -271 & -269 \\
\hline Trade balance (fob) & -750 & -894 & -877 & -853 & -881 & $-1,002$ & $-1,066$ & $-1,098$ & $-1,130$ & $-1,161$ \\
\hline Exports & 1,203 & 1,343 & 1,640 & 1,642 & 1,755 & 1,805 & 1,919 & 2,067 & 2,228 & 2,401 \\
\hline Imports & $-1,953$ & $-2,237$ & 2,517 & $-2,496$ & 2,636 & $-2,807$ & $-2,984$ & $-3,166$ & $-3,358$ & $-3,562$ \\
\hline Services (net) & -9 & -43 & -17 & -27 & -9 & -24 & -26 & -19 & -12 & -4 \\
\hline Income (net; including net interest) & -28 & -33 & -56 & -44 & -29 & -29 & -39 & -43 & -42 & -51 \\
\hline Transfers (net) & 650 & 637 & 662 & 863 & 677 & 878 & 911 & 934 & 961 & 996 \\
\hline Official 1/ & 89 & 55 & 58 & 52 & 45 & 58 & 60 & 53 & 48 & 50 \\
\hline Private & 561 & 582 & 604 & 811 & 633 & 820 & 851 & 881 & 913 & 946 \\
\hline Capital and financial account & 191 & 310 & 500 & 401 & 411 & 354 & 262 & 300 & 287 & 352 \\
\hline Capital account (net) & -6 & -4 & -4 & -2 & -4 & -4 & -4 & -4 & -4 & -4 \\
\hline Financial account & 197 & 314 & 504 & 403 & 415 & 358 & 266 & 304 & 290 & 356 \\
\hline Disbursements 2/ & 215 & 198 & 242 & 256 & 206 & 273 & 287 & 304 & 343 & 387 \\
\hline Amortization 2/ & -148 & -153 & -125 & -143 & -275 & -301 & -215 & -267 & -314 & -323 \\
\hline Direct and portfolio investment (net) & 84 & 138 & 288 & 275 & 404 & 412 & 177 & 216 & 259 & 288 \\
\hline Direct investment & 81 & 126 & 133 & 77 & 399 & 354 & 142 & 178 & 218 & 245 \\
\hline Portfolio investment & 3 & 11 & 155 & 198 & 5 & 58 & 36 & 38 & 40 & 43 \\
\hline Eurobond & 0 & 0 & 150 & 150 & 0 & 0 & 0 & 0 & 0 & 0 \\
\hline EBRD & 0 & 0 & 0 & 11 & 0 & 25 & 0 & 0 & 0 & 0 \\
\hline Other & 3 & 11 & 5 & 37 & 5 & 34 & 36 & 38 & 40 & 43 \\
\hline Currency and deposits (net) & -10 & -25 & 21 & -21 & -2 & -60 & -62 & -63 & -65 & -67 \\
\hline Individuals & 35 & 59 & 59 & -43 & 59 & -41 & -42 & -42 & -43 & -43 \\
\hline Commercial banks & -45 & -84 & -39 & 22 & -62 & -19 & -20 & -21 & -23 & -24 \\
\hline Short-term loans (net) & -13 & 20 & 0 & 14 & 0 & 0 & 0 & 0 & 0 & 0 \\
\hline Trade credits (net) & 69 & 136 & 79 & 21 & 82 & 34 & 79 & 114 & 67 & 71 \\
\hline Errors and omissions & -40 & 5 & 0 & -1 & 0 & 0 & 0 & 0 & 0 & 0 \\
\hline Overall balance & 14 & -19 & 212 & 340 & 169 & 177 & 42 & 73 & 64 & 133 \\
\hline Financing & -14 & 19 & -212 & -340 & -169 & -177 & -42 & -73 & -64 & -133 \\
\hline Net foreign assets (flows) & -16 & -4 & -196 & -355 & -169 & -177 & -42 & -73 & -64 & -133 \\
\hline Valuation effects on the stock of NFA (increase: -) & 0 & 3 & 0 & -47 & 0 & 0 & 0 & 0 & 0 & 0 \\
\hline Change in the stock of NFA (increase:-) & -16 & -1 & -196 & -401 & -169 & -177 & -42 & -73 & -64 & -133 \\
\hline Change in gross foreign reserves (increase:-) & -23 & -7 & -199 & -406 & -162 & -169 & -19 & -62 & -59 & -133 \\
\hline IMF (net) & -5 & -7 & 4 & 4 & -7 & -8 & -23 & -11 & -5 & 0 \\
\hline Disbursement & 15 & 10 & 12 & 13 & 0 & 0 & 0 & 0 & 0 & 0 \\
\hline Amortization & -19 & -16 & -8 & -9 & -7 & -8 & -23 & -11 & -5 & 0 \\
\hline Other (net) & 15 & 19 & 0 & 1 & 0 & 0 & 0 & 0 & 0 & 0 \\
\hline Change in arrears $3 /$ & -2 & 16 & -17 & 15 & 0 & 0 & 0 & 0 & 0 & 0 \\
\hline Financing gap & 0 & 0 & 0 & 0 & 0 & 0 & 0 & 0 & 0 & 0 \\
\hline \multicolumn{11}{|l|}{ Memorandum items: } \\
\hline Current account (in percent of GDP) & -3.4 & -7.7 & -6.5 & -1.4 & -5.2 & -3.7 & -4.3 & -4.2 & -3.9 & -3.6 \\
\hline Excluding official transfers & -5.5 & -9.0 & -7.8 & -2.5 & -6.1 & -4.9 & -5.5 & -5.2 & -4.7 & -4.4 \\
\hline Trade balance (in percent of GDP) & -18.3 & -20.7 & -19.9 & -18.9 & -18.9 & -21.0 & -21.1 & -20.4 & -19.7 & -18.9 \\
\hline Export growth rate (percent) & 2.5 & 11.6 & 22.1 & 22.3 & 7.0 & 9.8 & 6.3 & 7.8 & 7.8 & 7.8 \\
\hline Import growth rate (percent) & -3.4 & 14.5 & 12.2 & 11.6 & 4.7 & 12.5 & 6.3 & 6.1 & 6.1 & 6.1 \\
\hline Non-oil trade balance (in percent of GDP) & -13.2 & -15.4 & -14.2 & -11.3 & -13.7 & -12.0 & -12.7 & -12.0 & -11.3 & -10.6 \\
\hline Gross reserves & 710 & 717 & 916 & 1,123 & 1,078 & 1,292 & 1,312 & 1,374 & 1,433 & 1,565 \\
\hline (in months of following year's imports of gnfs) & 3.2 & 2.8 & 3.6 & 4.0 & 4.0 & 4.3 & 4.1 & 4.1 & 4.0 & 4.1 \\
\hline External debt service ratio (in percent) 4/ & 18.7 & 13.9 & 15.6 & 15.2 & 24.7 & 23.2 & 16.4 & 16.1 & 14.6 & 15.0 \\
\hline Total external debt (in percent of GDP) & 42.4 & 44.8 & 46.7 & 45.6 & 45.0 & 42.3 & 42.0 & 41.8 & 41.0 & 42.2 \\
\hline Medium and long-term debt & 37.2 & 36.4 & 37.4 & 37.4 & 34.5 & 34.5 & 33.1 & 31.3 & 30.0 & 30.8 \\
\hline Short-term debt 5/ & 5.2 & 8.4 & 9.3 & 8.2 & 10.5 & 7.8 & 8.9 & 10.5 & 11.0 & 11.5 \\
\hline Net private transfers (in percent of GDP) & 13.7 & 13.4 & 13.7 & 18.0 & 13.6 & 17.2 & 16.8 & 16.3 & 15.9 & 15.4 \\
\hline Nominal GDP (in millions of euros) & 4,095 & 4,325 & 4,411 & 4,505 & 4,668 & 4,771 & 5,061 & 5,394 & 5,750 & 6,129 \\
\hline
\end{tabular}

Sources: Data provided by the FYRM authorities and IMF staff estimates and projections.

1/ Based on historical outcomes, official transfers for BOP projections are lower than initial budget projections.

2/ Increase in projections for 2005 and 2006 is due to increased projections for private sector external financing.

3/ Private sector arrears.

4/ Debt service due including for debt to the IMF as percent of exports of goods and services. Excludes rollover of trade credit.

5 / Including trade credit. 
Table 3. FYR Macedonia: Central Government Operations, 2004-06

\begin{tabular}{|c|c|c|c|c|c|}
\hline & \multirow{2}{*}{$\begin{array}{r}2004 \\
\text { Actual } \\
\end{array}$} & \multicolumn{2}{|c|}{2005} & \multicolumn{2}{|c|}{2006} \\
\hline & & Prog. & Actual & Budget & Proj. \\
\hline & \multicolumn{5}{|c|}{ (in billions of denars) } \\
\hline Total revenue and grants & 96.9 & 105.3 & 100.9 & 102.4 & 102.9 \\
\hline Tax revenue & 81.6 & 83.8 & 84.6 & 87.4 & 87.0 \\
\hline Taxes on income and profits & 10.1 & 10.8 & 10.9 & 11.2 & 11.2 \\
\hline Social insurance contributions $1 /$ & 28.1 & 29.6 & 28.6 & 29.6 & 28.6 \\
\hline Domestic taxes on goods \& services & 36.8 & 37.8 & 38.8 & 40.9 & 41.5 \\
\hline VAT & 25.8 & 26.3 & 27.1 & 28.3 & 28.3 \\
\hline Excises & 11.0 & 11.5 & 11.7 & 12.5 & 13.1 \\
\hline Import duties & 5.8 & 4.9 & 5.3 & 4.8 & 4.8 \\
\hline Other taxes & 0.8 & 0.8 & 1.0 & 0.8 & 0.8 \\
\hline Non-tax and capital revenue & 13.6 & 17.2 & 14.9 & 13.4 & 13.9 \\
\hline Non-tax revenue & 13.0 & 13.3 & 10.6 & 11.9 & 11.9 \\
\hline Capital revenue 2/ & 0.6 & 3.9 & 4.3 & 1.5 & 2.0 \\
\hline Grants & 1.7 & 4.2 & 1.5 & 1.6 & 2.0 \\
\hline Total expenditures & 95.8 & 107.5 & 100.2 & 104.1 & 104.8 \\
\hline Total expenditures, w/o errors \& omissions & 95.0 & 107.5 & 100.2 & 104.2 & 104.8 \\
\hline Current expenditure & 86.7 & 92.8 & 90.0 & 92.6 & 93.2 \\
\hline Goods and services & 34.2 & 37.4 & 35.8 & 36.5 & 36.5 \\
\hline Wages and salaries & 22.0 & 23.2 & 22.8 & 24.0 & 24.0 \\
\hline Goods and nonlabor services & 12.1 & 14.1 & 12.8 & 12.4 & 12.4 \\
\hline Reserves & 0.1 & 0.2 & 0.2 & 0.2 & 0.2 \\
\hline Transfers & 50.2 & 52.7 & 51.6 & 52.8 & 53.4 \\
\hline Interest & 2.3 & 2.7 & 2.6 & 3.3 & 3.3 \\
\hline Domestic & 0.9 & 1.1 & 1.1 & 1.2 & 1.2 \\
\hline Foreign & 1.4 & 1.5 & 1.5 & 2.1 & 2.1 \\
\hline Capital expenditure & 8.4 & 14.7 & 10.2 & 11.5 & 11.5 \\
\hline Lending minus repayments & 0.0 & 0.0 & 0.0 & 0.0 & 0.0 \\
\hline Statistical discrepancy/Measures & 0.8 & 0.0 & 0.0 & 0.0 & 0.0 \\
\hline Consolidated central govt. fiscal balance & 1.1 & -2.2 & 0.7 & -1.7 & -1.9 \\
\hline Balance excluding NBRM recapitalization & & -1.0 & 2.0 & & \\
\hline Financing & -1.1 & 2.2 & -0.7 & 1.7 & 1.9 \\
\hline Domestic & -2.3 & -9.9 & -12.2 & 6.6 & 6.7 \\
\hline Bank financing & -0.7 & -8.2 & -10.3 & -6.8 & -6.7 \\
\hline Central bank & -1.0 & -9.1 & -10.2 & -7.8 & -7.6 \\
\hline Commercial banking system & 0.4 & 0.8 & 0.0 & 1.0 & 1.0 \\
\hline o/w T-bills issue (starting 2004) & 0.6 & 1.0 & 0.4 & 1.5 & 1.5 \\
\hline Other domestic financing & -2.2 & -2.2 & -2.5 & -2.3 & -2.3 \\
\hline Privatization receipts & 0.5 & 0.5 & 0.5 & 15.7 & 15.7 \\
\hline Foreign & 1.3 & 12.2 & 11.5 & -4.9 & -4.9 \\
\hline Unidentified financing & 0.0 & 0.0 & 0.0 & 0.0 & 0.0 \\
\hline \multicolumn{6}{|l|}{ Memorandum item: } \\
\hline Nominal GDP & 265.3 & 276.7 & 276.7 & 293.1 & 293.1 \\
\hline
\end{tabular}

Sources: Data provided by the authorities; and IMF staff projections.

1/ Excluding contributions transfered to the 2nd pillar pension scheme that commenced in 2006.

2/ From 2005 onwards capital revenue includes dividends, interest and other property income previously reported under non-tax revenue. 
Table 3 (continued). FYR Macedonia: Central Government Operations, 2004-06

\begin{tabular}{|c|c|c|c|c|c|}
\hline & \multirow{2}{*}{$\begin{array}{r}2004 \\
\text { Actual }\end{array}$} & \multicolumn{2}{|c|}{2005} & \multicolumn{2}{|c|}{2006} \\
\hline & & Prog. 3/ & Actual & Budget & Proj. \\
\hline & \multicolumn{5}{|c|}{ (in percent of GDP) } \\
\hline Total revenue and grants & 36.5 & 38.0 & 36.5 & 34.9 & 35.1 \\
\hline Tax revenue & 30.8 & 30.3 & 30.6 & 29.8 & 29.7 \\
\hline Taxes on income and profits & 3.8 & 3.9 & 4.0 & 3.8 & 3.8 \\
\hline Social insurance contributions $1 /$ & 10.6 & 10.7 & 10.3 & 10.1 & 9.8 \\
\hline Domestic taxes on goods \& services & 13.9 & 13.7 & 14.0 & 13.9 & 14.2 \\
\hline VAT & 9.7 & 9.5 & 9.8 & 9.7 & 9.7 \\
\hline Excises & 4.1 & 4.1 & 4.2 & 4.3 & 4.5 \\
\hline Import duties & 2.2 & 1.8 & 1.9 & 1.7 & 1.7 \\
\hline Other taxes & 0.3 & 0.3 & 0.3 & 0.3 & 0.3 \\
\hline Non-tax and capital revenue & 5.1 & 6.2 & 5.4 & 4.6 & 4.8 \\
\hline Non-tax revenue & 4.9 & 4.8 & 3.8 & 4.1 & 4.1 \\
\hline Capital revenue 2/ & 0.2 & 1.4 & 1.5 & 0.5 & 0.7 \\
\hline Grants & 0.6 & 1.5 & 0.5 & 0.5 & 0.7 \\
\hline Total expenditures & 36.1 & 38.8 & 36.2 & 35.5 & 35.7 \\
\hline Total expenditures, w/o errors \& omissions & 35.8 & 38.8 & 36.2 & 35.5 & 35.7 \\
\hline Current expenditure & 32.7 & 33.5 & 32.5 & 31.6 & 31.8 \\
\hline Goods and services & 12.9 & 13.5 & 12.9 & 12.5 & 12.5 \\
\hline Wages and salaries & 8.3 & 8.4 & 8.3 & 8.2 & 8.2 \\
\hline Goods and nonlabor services & 4.5 & 5.1 & 4.6 & 4.2 & 4.2 \\
\hline Reserves & 0.1 & 0.1 & 0.1 & 0.1 & 0.1 \\
\hline Transfers $1 /$ & 18.9 & 19.0 & 18.6 & 18.0 & 18.2 \\
\hline Interest & 0.9 & 1.0 & 0.9 & 1.1 & 1.1 \\
\hline Domestic & 0.4 & 0.4 & 0.4 & 0.4 & 0.4 \\
\hline Foreign & 0.5 & 0.6 & 0.6 & 0.7 & 0.7 \\
\hline Capital expenditure & 3.2 & 5.3 & 3.7 & 3.9 & 3.9 \\
\hline Lending minus repayments & 0.0 & 0.0 & 0.0 & 0.0 & 0.0 \\
\hline Statistical discrepancy/Measures & 0.3 & 0.0 & 0.0 & 0.0 & 0.0 \\
\hline Consolidated central govt. fiscal balance & 0.4 & -0.8 & 0.3 & -0.6 & -0.6 \\
\hline Balance excluding NBRM recapitalization & & -0.4 & 0.7 & & \\
\hline Financing & -0.4 & 0.8 & -0.3 & 0.6 & 0.6 \\
\hline Domestic & -0.9 & -3.6 & -4.4 & 2.3 & 2.3 \\
\hline Bank financing & -0.2 & -3.0 & -3.7 & -2.3 & -2.3 \\
\hline Central bank & -0.4 & -3.3 & -3.7 & -2.7 & -2.6 \\
\hline Commercial banking system & 0.1 & 0.3 & 0.0 & 0.3 & 0.3 \\
\hline o/w T-bills issue (starting 2004) & 0.2 & 0.4 & 0.1 & 0.5 & 0.5 \\
\hline Other domestic financing & -0.8 & -0.8 & -0.9 & -0.8 & -0.8 \\
\hline Privatization receipts & 0.2 & 0.2 & 0.2 & 5.4 & 5.4 \\
\hline Foreign & 0.5 & 4.4 & 4.1 & -1.7 & -1.7 \\
\hline Unidentified financing & 0.0 & 0.0 & 0.0 & 0.0 & 0.0 \\
\hline \multicolumn{6}{|l|}{ Memorandum item: } \\
\hline Nominal GDP & 265.3 & 276.7 & 276.7 & 293.1 & 293.1 \\
\hline
\end{tabular}

Sources: Data provided by the authorities; and IMF staff projections.

1/ Excluding contributions transfered to the 2nd pillar pension scheme that commenced in 2006.

2/ From 2005 onwards capital revenue includes dividends, interest and other property income previously reported under non-tax revenue.

3/ The ratios differ from the original program document due to revision of the GDP estimates. 
Table 4. FYR Macedonia: Central Bank Accounts, 2004-06

\begin{tabular}{|c|c|c|c|c|c|c|c|c|c|}
\hline & \multirow{2}{*}{$\begin{array}{c}2004 \\
\text { Dec. } \\
\text { Actual }\end{array}$} & \multicolumn{4}{|c|}{2005} & \multicolumn{4}{|c|}{2006} \\
\hline & & $\begin{array}{r}\text { Mar. } \\
\text { Actual }\end{array}$ & $\begin{array}{r}\text { Jun. } \\
\text { Actual }\end{array}$ & $\begin{array}{r}\text { Sep. } \\
\text { Actual }\end{array}$ & $\begin{array}{r}\text { Dec. } \\
\text { Actual }\end{array}$ & $\begin{array}{l}\text { Mar. } \\
\text { Proj. }\end{array}$ & $\begin{array}{l}\text { Jun. } \\
\text { Proj. }\end{array}$ & $\begin{array}{l}\text { Sep. } \\
\text { Proj. }\end{array}$ & $\begin{array}{l}\text { Dec. } \\
\text { Proj. }\end{array}$ \\
\hline & \multicolumn{9}{|c|}{ (in billions of denars at current exchange rate) } \\
\hline Net foreign assets & 41.8 & 43.1 & 45.8 & 51.1 & 66.3 & 60.7 & 66.8 & 70.8 & 77.1 \\
\hline Net domestic assets & -20.7 & -21.4 & -22.9 & -28.4 & -40.5 & -37.1 & -42.8 & -45.8 & -50.8 \\
\hline Banks (net) & -4.5 & -6.0 & -6.0 & -6.4 & -8.9 & -11.4 & -8.6 & -12.3 & -11.3 \\
\hline o/w Instruments (NBRM bills) & -4.6 & -6.0 & -6.1 & -6.5 & -8.9 & -11.5 & -8.6 & -12.4 & -11.3 \\
\hline Government (net) $1 /$ & -8.1 & -6.8 & -7.2 & -11.5 & -19.0 & -13.1 & -21.5 & -20.7 & -26.6 \\
\hline o/w Deposits & -11.0 & -9.6 & -9.7 & -14.1 & -22.3 & -16.3 & -24.8 & -24.0 & -29.9 \\
\hline Other items (net) & -8.1 & -8.6 & -9.7 & -10.4 & -12.7 & -12.7 & -12.8 & -12.8 & -12.9 \\
\hline Reserve money & 21.1 & 21.8 & 23.0 & 22.7 & 25.8 & 23.5 & 24.0 & 25.0 & 26.3 \\
\hline Currency & 14.2 & 13.2 & 13.4 & 13.5 & 14.4 & 13.4 & 13.7 & 13.9 & 14.9 \\
\hline Other & 6.9 & 8.6 & 9.6 & 9.2 & 11.3 & 10.1 & 10.3 & 11.1 & 11.4 \\
\hline Cash in vaults & 0.9 & 0.8 & 0.9 & 0.9 & 1.4 & 1.0 & 1.0 & 1.0 & 1.0 \\
\hline \multirow[t]{2}{*}{ Total reserves } & 6.0 & 7.8 & 8.7 & 8.3 & 9.9 & 9.1 & 9.3 & 10.1 & 10.4 \\
\hline & \multicolumn{9}{|c|}{ (year-on-year growth rates) } \\
\hline Net foreign assets & -1.6 & 1.5 & 12.2 & 19.7 & 58.5 & 40.6 & 45.9 & 38.7 & 16.4 \\
\hline Net domestic assets & -3.6 & -11.6 & 6.8 & 22.1 & 95.6 & 73.9 & 87.4 & 61.5 & 25.4 \\
\hline Reserve money & 0.4 & 17.2 & 24.6 & 7.5 & 22.0 & 7.9 & 4.5 & 10.2 & 2.1 \\
\hline \multirow[t]{2}{*}{ Currency } & -0.1 & 0.7 & 1.7 & -4.7 & 2.0 & 1.5 & 2.2 & 3.3 & 3.1 \\
\hline & \multicolumn{9}{|c|}{ (in billions of denars at constant exchange rate) } \\
\hline Net foreign assets & 41.8 & 42.6 & 44.2 & 49.2 & 63.7 & 58.0 & 64.2 & 68.2 & 74.5 \\
\hline Net domestic assets & -20.7 & -20.8 & -21.3 & -26.5 & -37.9 & -34.5 & -40.2 & -43.2 & -48.2 \\
\hline $\mathrm{o} / \mathrm{w}$ credit to the government & -8.1 & -6.7 & -7.0 & -11.5 & -19.0 & -13.1 & -21.5 & -20.7 & -26.6 \\
\hline Reserve money & 21.1 & 21.8 & 23.0 & 22.7 & 25.8 & 23.5 & 24.0 & 25.0 & 26.3 \\
\hline \multicolumn{10}{|l|}{ Memorandum items: } \\
\hline Program exchange rate (Denars per euro) & 61.3 & 61.3 & 61.3 & 61.3 & 61.3 & 61.3 & 61.3 & 61.3 & 61.3 \\
\hline
\end{tabular}

Sources: The National Bank of the Republic of Macedonia; and IMF staff projections.

1/ The difference between the central government financing from the NBRM in the fiscal table and in the NBRM balance sheet for 2005 is caused by denar 679 million of changes in municipal accounts. 
Table 5. FYR Macedonia: Monetary Survey, 2004-06

\begin{tabular}{|c|c|c|c|c|c|c|c|c|c|}
\hline & \multirow{2}{*}{$\begin{array}{r}2004 \\
\text { Dec. } \\
\text { Actual } \\
\end{array}$} & \multicolumn{4}{|c|}{2005} & \multicolumn{4}{|c|}{2006} \\
\hline & & $\begin{array}{r}\text { Mar. } \\
\text { Actual }\end{array}$ & $\begin{array}{r}\text { Jun. } \\
\text { Actual } \\
\end{array}$ & $\begin{array}{r}\text { Sep. } \\
\text { Actual } \\
\end{array}$ & $\begin{array}{r}\text { Dec. } \\
\text { Actual } \\
\end{array}$ & $\begin{array}{l}\text { Mar. } \\
\text { Proj. }\end{array}$ & $\begin{array}{l}\text { Jun. } \\
\text { Proj. }\end{array}$ & $\begin{array}{l}\text { Sep. } \\
\text { Proj. }\end{array}$ & $\begin{array}{l}\text { Dec. } \\
\text { Proj. }\end{array}$ \\
\hline & \multicolumn{9}{|c|}{ (in billions of denars at current exchange rate) } \\
\hline Net foreign assets & 68.9 & 68.4 & 74.4 & 75.3 & 89.7 & 84.2 & 91.3 & 96.0 & 101.7 \\
\hline National Bank of Macedonia (NBRM) & 41.8 & 43.1 & 45.8 & 51.1 & 66.3 & 60.7 & 66.8 & 70.8 & 77.1 \\
\hline Domestic money banks (DMB) & 27.0 & 25.3 & 28.6 & 24.3 & 23.5 & 23.5 & 24.5 & 25.1 & 24.6 \\
\hline Net domestic assets & 25.9 & 29.8 & 30.2 & 27.0 & 19.2 & 29.8 & 24.6 & 29.3 & 28.0 \\
\hline Credit to the government & -1.2 & 0.8 & 0.3 & -4.4 & -12.2 & -6.0 & -14.1 & -13.1 & -18.8 \\
\hline Banks & 6.9 & 7.5 & 7.5 & 7.1 & 6.8 & 7.1 & 7.4 & 7.5 & 7.8 \\
\hline NBRM (net) & -8.1 & -6.8 & -7.2 & -11.5 & -19.0 & -13.1 & -21.5 & -20.7 & -26.6 \\
\hline Credit to the private sector & 57.1 & 60.3 & 63.0 & 65.8 & 68.8 & 73.2 & 76.3 & 80.0 & 84.5 \\
\hline In denars $1 /$ & 45.8 & 47.4 & 48.6 & 49.8 & 51.7 & 55.1 & 57.2 & 60.4 & 64.0 \\
\hline In foreign currency & 11.3 & 12.9 & 14.4 & 16.1 & 17.1 & 18.1 & 19.1 & 19.6 & 20.5 \\
\hline Other items (net) & -30.0 & -31.3 & -33.1 & -34.4 & -37.4 & -37.4 & -37.6 & -37.6 & -37.7 \\
\hline Broad money (M3) & 94.8 & 98.2 & 104.6 & 102.3 & 108.9 & 114.0 & 116.0 & 125.2 & 129.7 \\
\hline Currency in circulation & 14.2 & 13.2 & 13.4 & 13.5 & 14.4 & 13.4 & 13.7 & 13.9 & 14.9 \\
\hline Private denar deposits $2 /$ & 38.1 & 40.9 & 43.9 & 38.9 & 43.4 & 47.6 & 46.4 & 52.1 & 53.8 \\
\hline \multirow[t]{2}{*}{ Private foreign currency deposits } & 42.5 & 44.0 & 47.3 & 49.9 & 51.1 & 53.1 & 55.9 & 59.2 & 61.1 \\
\hline & \multicolumn{9}{|c|}{ (year-on-year growth rates) } \\
\hline NFA domestic money banks & 16.1 & 8.7 & 15.4 & -6.0 & -13.3 & -6.9 & -14.3 & 3.6 & 4.9 \\
\hline Credit to the private sector & 25.0 & 25.3 & 23.2 & 22.0 & 20.5 & 21.4 & 21.2 & 21.5 & 22.8 \\
\hline Denar credit & 19.0 & 17.7 & 12.7 & 10.5 & 12.9 & 16.3 & 17.8 & 21.3 & 23.8 \\
\hline Foreign currency credit & 56.6 & 63.9 & 79.2 & 80.1 & 50.7 & 40.2 & 32.3 & 22.1 & 20.0 \\
\hline Broad Money & 16.1 & 20.9 & 21.1 & 13.4 & 14.9 & 16.1 & 10.9 & 22.4 & 19.1 \\
\hline Private denar deposits & 15.5 & 27.8 & 26.5 & 6.8 & 13.8 & 16.2 & 5.6 & 33.9 & 23.9 \\
\hline \multirow[t]{2}{*}{ Private foreign currency deposits } & 23.3 & 21.6 & 23.3 & 23.3 & 20.2 & 20.5 & 18.2 & 18.6 & 19.5 \\
\hline & \multicolumn{9}{|c|}{ (in billions of denars at constant exchange rate) } \\
\hline Net foreign assets & 68.9 & 67.7 & 72.4 & 73.2 & 86.7 & 81.2 & 88.3 & 93.0 & 98.7 \\
\hline Net domestic assets & 25.9 & 30.2 & 31.4 & 28.3 & 21.3 & 32.0 & 26.8 & 31.4 & 30.1 \\
\hline $\mathrm{o} / \mathrm{w}$ credit to the government & -1.2 & 0.7 & 0.4 & -4.4 & -12.2 & -6.0 & -14.1 & -13.1 & -18.8 \\
\hline Broad money (M3) & 94.8 & 97.8 & 103.8 & 101.5 & 108.1 & 113.2 & 115.1 & 124.4 & 128.9 \\
\hline \multicolumn{10}{|l|}{ Memorandum items: } \\
\hline Velocity of M3 & 0.36 & 0.37 & 0.39 & 0.37 & 0.39 & 0.41 & 0.41 & 0.43 & 0.44 \\
\hline Private credit (percent change from end of previous year) & 25.0 & 5.6 & 10.4 & 15.3 & 20.5 & 6.5 & 11.0 & 16.3 & 22.8 \\
\hline NFA of DMBs in percent of private FX deposits 3/ & 71.5 & 68.2 & 70.7 & 59.1 & 56.3 & 54.4 & 53.8 & 52.5 & 50.3 \\
\hline Share of $\mathrm{fx}$ deposits in total deposits & 0.53 & 0.52 & 0.52 & 0.56 & 0.54 & 0.53 & 0.55 & 0.53 & 0.53 \\
\hline Nominal GDP billions of denar & 265.3 & 266.7 & 270.5 & 273.7 & 276.7 & 280.5 & 284.6 & 288.6 & 293.1 \\
\hline
\end{tabular}

Sources: The National Bank of the Republic of Macedonia; and IMF staff projections.

$1 /$ Includes foreign currency indexed.

2/ Includes municipal and public enterprise accounts.

3/ Includes required reserves (RR) on FX deposits. 
Table 6. FYR Macedonia: Requests for Waivers and Revisions to Program Targets

\section{Requested action Comments}

\section{Structural performance criteria}

PRO designs new organizational chart The authorities request a waiver and fills identified positions required to of nonobservance. implement payroll tax reform (endDecember 2005).

Government to submit new Banking Law to Parliament (end-December 2005).

The authorities request a waiver of nonobservance.
The organizational restructuring process took longer than expected, and the positions have now been filled.

The authorities prepared a first draft but have now decided on a more comprehensive reform. The staff supports this new strategy since it will allow for greater MFD and LEG involvement, which should improve the final draft, and should also allow strengthening of the Deposit Insurance Law. A draft in line with the recommendations of a forthcoming TA mission will be prepared by end-September 2006 (new structural benchmark), and will be submitted to Parliament by end-December 2006 (performance criterion to be set at Second Review).

\section{Quantitative performance criteria} Ceiling on HIF arrears (end-December 2005).

All quantitative end-March performance criteria.
The authorities request a waiver The increase since end-2004 was only 317 million of nonobservance, and to convert denars ( 0.1 percent of GDP); arrears started to fall in this to an indicative target on completion of this review. the last quarter of 2005. Measures implemented by the authorities during the second half of 2005 and agreed at this First Review should contain the stock of HIF arrears and progressively reduce them to their end-2004 level.

The authorities request a waiver of applicability.
Data will not be available to monitor performance at the time of the Board meeting. However, with the exception of HIF arrears (see above), all quantitative PCs for end-December were met and there is no clear evidence that the end-March targets will not be met.

The authorities have agreed to raise the NIR and NDA performance criteria by $€ 100$ million, phased according to Table 1 of the Letter of Intent. Given uncertainties over projected privatization receipts, the authorities request a $€ 50$ million increase in the cap to the privatization adjustor to the NIR and NDA targets. ceiling on net domestic assets of the NBRM.
Reset quantitative performance criteria for June, September and December 2006. Revision of the TMU. 
Table 7. FYR Macedonia: External Financing Requirements and Sources, 2003-09 (In millions of Euro)

\begin{tabular}{|c|c|c|c|c|c|c|c|c|c|}
\hline & \multirow{2}{*}{$\begin{array}{r}2003 \\
\text { Act. }\end{array}$} & \multirow{2}{*}{$\begin{array}{c}2004 \\
\text { Prel. }\end{array}$} & \multicolumn{2}{|c|}{2005} & \multicolumn{2}{|c|}{2006} & \multirow{2}{*}{$\begin{array}{l}2007 \\
\text { Proj. }\end{array}$} & \multirow{2}{*}{$\begin{array}{l}2008 \\
\text { Proj. }\end{array}$} & \multirow{2}{*}{$\begin{array}{l}2009 \\
\text { Proj. }\end{array}$} \\
\hline & & & Program & Prel. & Program & Proj. & & & \\
\hline 1. Gross Financing Requirement & 416 & 565 & 679 & 672 & 731 & 714 & 538 & 619 & 648 \\
\hline External current account deficit (excl. official transfers) & 227 & 389 & 345 & 114 & 287 & 235 & 280 & 280 & 271 \\
\hline Debt amortization 1/ & 148 & 153 & 125 & 143 & 275 & 301 & 215 & 267 & 314 \\
\hline IMF/BIS repurchases and repayments (net) & 19 & 16 & 8 & 9 & 7 & 8 & 23 & 11 & 5 \\
\hline 2. Identified Financing & 416 & 565 & 679 & 672 & 731 & 714 & 538 & 619 & 648 \\
\hline IMF/BIS purchases and disbursements & 15 & 10 & 12 & 13 & 0 & 0 & 0 & 0 & 0 \\
\hline Foreign direct investment (net) & 81 & 126 & 133 & 77 & 399 & 354 & 142 & 178 & 218 \\
\hline Other flows $2 /$ & 118 & 246 & 400 & 425 & 81 & 176 & 216 & 294 & 300 \\
\hline Accumulation of arrears $3 /$ & -2 & 16 & -17 & 15 & 0 & 0 & 0 & 0 & 0 \\
\hline 3. Financing Gap (1 - 2) & 0 & 0 & 0 & 0 & 0 & 0 & 0 & 0 & 0 \\
\hline \multicolumn{10}{|l|}{ Memorandum items: } \\
\hline
\end{tabular}

Sources: Data provided by the NBRM and IMF staff estimates and projections.
1/ Excluding the IMF.
2/ Includes all other net financial flows and errors and omissions.
3/ Private sector and public enterprise arrears.
4/ Program rates used for projections. 
Table 8. FYR Macedonia. Indicators of Financial and External Vulnerability, 2001-05

\begin{tabular}{|c|c|c|c|c|c|}
\hline & $\begin{array}{r}2001 \\
\text { Actual }\end{array}$ & $\begin{array}{r}2002 \\
\text { Actual }\end{array}$ & $\begin{array}{r}2003 \\
\text { Actual }\end{array}$ & $\begin{array}{r}2004 \\
\text { Actual }\end{array}$ & $\begin{array}{l}2005 \\
\text { Prel. }\end{array}$ \\
\hline \multicolumn{6}{|l|}{ Financial indicators } \\
\hline Broad money (end of period; percent change from end of previous year) & 62.6 & -10.0 & 18.0 & 16.1 & 14.9 \\
\hline Private sector credit (end of period; percent change from end of previous year) 1 / & 2.1 & -0.9 & 19.0 & 25.0 & 20.5 \\
\hline Share of non-performing loans in total bank exposure (end of period, in percent) & 33.7 & 15.9 & 10.2 & 8.9 & 7.4 \\
\hline NPLs of nonfinancial private sector/gross loans to nonfinancial private sector (percent) & $\ldots$ & $\ldots$ & 22.3 & 17.0 & 14.3 \\
\hline Foreign currency deposits (end of period, in percent of broad money) & 45.8 & 40.3 & 42.2 & 44.8 & 46.9 \\
\hline Indexed and foreign currency credit to private sector & & & & & \\
\hline (end of period, in percent of total credit to private sector) & $\ldots$ & $\ldots$ & 37.6 & 41.2 & 45.8 \\
\hline Central bank short-term foreign liabilities (in millions of Euro) & 0.0 & 2.0 & 0.0 & 0.7 & 0.0 \\
\hline Short term foreign assets of commercial banks (in millions of Euro) & 876 & 609 & 624 & 714 & $\ldots$ \\
\hline Short term foreign liabilities of commercial banks (in millions of Euro) & 771 & 555 & 627 & 743 & $\ldots$ \\
\hline Money market rate (end of period; in percent) & 11.9 & 14.4 & 6.8 & 8.3 & 9.2 \\
\hline \multicolumn{6}{|l|}{ External Indicators } \\
\hline Exports (percent change, in terms of Euro) & -10.0 & -9.0 & 2.5 & 11.6 & 22.3 \\
\hline Imports (percent change, in terms of Euro) & -13.8 & 7.5 & -3.4 & 14.5 & 11.6 \\
\hline \multicolumn{6}{|l|}{ Current account balance (in percent of GDP) } \\
\hline (Including official grants) & -7.2 & -9.5 & -3.4 & -7.7 & -1.4 \\
\hline (Excluding official grants) & -8.7 & -12.2 & -5.5 & -9.0 & -2.5 \\
\hline Foreign direct investment (in percent of GDP) & 12.4 & 2.0 & 2.0 & 2.9 & 1.7 \\
\hline Gross official reserves (in EUR) & 857 & 700 & 710 & 717 & 1,123 \\
\hline (In months of next year's imports of goods and services) & 4.3 & 3.6 & 3.2 & 2.8 & 4.0 \\
\hline (In percent of private denar broad money) & 132.7 & 104.0 & 93.3 & 85.0 & 120.0 \\
\hline Total external debt (in percent of GDP) & 42.7 & 44.4 & 42.4 & 44.8 & 45.6 \\
\hline \multicolumn{6}{|l|}{ Short-term debt (by remaining maturity, including trade credit) } \\
\hline (In percent of GDP) & 3.2 & 4.6 & 5.2 & 8.4 & 8.2 \\
\hline (In percent of official reserves) & 14.2 & 26.4 & 29.9 & 50.9 & 32.7 \\
\hline External debt service payments (in percent of exports of goods and services) 2/ & 18.4 & 22.0 & 18.7 & 13.9 & 15.2 \\
\hline Exchange rate (denar per U.S. dollar, period average) & 68.0 & 64.7 & 54.3 & 49.4 & 49.3 \\
\hline \multicolumn{6}{|l|}{ REER (average percent change; (-) depreciation) } \\
\hline CPI-based & -7.6 & -2.5 & -0.1 & -1.6 & -3.2 \\
\hline ULC-based & -18.2 & -6.6 & -11.0 & 7.4 & $\ldots$ \\
\hline
\end{tabular}

Source: Staff calculations and estimates based on the data provided by the NBRM.

1/ 2001-02 credit growth affected by loan loss provisions.

$2 /$ Excluding trade credit. 
Table 9. FYR Macedonia: Indicators of Capacity to Repay the Fund, 2003-10 1/ (Under Obligation)

\begin{tabular}{|c|c|c|c|c|c|c|c|c|}
\hline & 2003 & 2004 & 2005 & 2006 & 2007 & 2008 & 2009 & 2010 \\
\hline & Act. & Act. & Prel. & \multicolumn{5}{|c|}{ Projections } \\
\hline \multicolumn{9}{|l|}{ Fund repurchases and charges } \\
\hline In millions of SDRs & 16.2 & 14.3 & 8.2 & 7.8 & 13.7 & 12.9 & 9.5 & 4.9 \\
\hline In millions of Euros & 21.0 & 17.8 & 9.4 & 9.5 & 16.6 & 15.5 & 11.5 & 5.9 \\
\hline In percent of exports of goods and services & 1.4 & 1.1 & 0.5 & 0.4 & 0.7 & 0.6 & 0.4 & 0.2 \\
\hline In percent of debt service & 10.7 & 9.0 & 5.7 & 2.6 & 4.5 & 4.6 & 3.0 & 1.4 \\
\hline In percent of quota & 23.8 & 20.8 & 13.4 & 11.4 & 19.9 & 18.7 & 13.8 & 7.1 \\
\hline In percent of gross official reserves & 3.0 & 2.5 & 0.9 & 0.7 & 1.3 & 1.1 & 0.8 & 0.4 \\
\hline \multicolumn{9}{|l|}{ Fund credit outstanding (e.o.p.) } \\
\hline In millions of SDRs & 46.0 & 40.3 & 43.5 & 37.0 & 24.9 & 13.2 & 4.5 & 0.0 \\
\hline In millions of Euros & 59.7 & 49.9 & 49.8 & 44.9 & 30.2 & 16.0 & 5.4 & 0.0 \\
\hline In percent of quota & 66.8 & 58.4 & 64.0 & 53.7 & 36.1 & 19.2 & 6.5 & 0.0 \\
\hline In percent of GDP & 1.5 & 1.2 & 1.1 & 0.9 & 0.6 & 0.3 & 0.1 & 0.0 \\
\hline In percent of gross official reserves & 8.4 & 7.0 & 4.5 & 3.5 & 2.3 & 1.2 & 0.4 & 0.0 \\
\hline \multicolumn{9}{|l|}{ Memorandum items: } \\
\hline Exports of goods and services (millions of Euros) & 1,495 & 1,672 & 2,038 & 2,242 & 2,381 & 2,566 & 2,765 & 2,980 \\
\hline Debt service (millions of Euros) & 199 & 198 & 186 & 372 & 283 & 337 & 386 & 407 \\
\hline Quota (millions of SDRs) & 69 & 69 & 69 & 69 & 69 & 69 & 69 & 69 \\
\hline Quota (millions of Euros) & 89 & 85 & 79 & 84 & 83 & 83 & 83 & 83 \\
\hline Gross official reserves (millions of Euros) & 710 & 717 & 1,123 & 1,292 & 1,312 & 1,374 & 1,433 & 1,565 \\
\hline GDP (millions of Euros) & 4,095 & 4,325 & 4,505 & 4,771 & 5,061 & 5,394 & 5,750 & 6,129 \\
\hline Euros per SDR & 1.3 & 1.2 & 1.1 & 1.2 & 1.2 & 1.2 & 1.2 & 1.2 \\
\hline
\end{tabular}

Sources: Data provided by the NBRM and IMF staff estimates and projections.

1/ As of February 28, 2006. Assumes no further purchases. 


\section{FYR Macedonia—EU Candidate Status: A Roadmap for Reform.}

The European Council's decision to grant FYR Macedonia candidate status - the only country currently with this designation but not yet with a firm negotiation start date-was based on progress fulfilling the Ohrid Framework Agreement and Macedonia's track record implementing the 2001 and 2004 Stabilization and Association Agreements (SAA).

What are the main requirements to start EU membership negotiations? In its decision, the Council stressed FYR Macedonia would need to reach a sufficient degree of conformity with the following membership criteria: (i) Copenhagen criteria; (ii) requirements of the SAA; and (iii) priorities identified within the avis and 2005 European Partnership. However, the Council clearly indicated that any future decision on membership would need to take into account the absorption capacity and enlargement strategy of the European Union.

As a candidate country, what are the main reform priorities? The EU framework provides a clear roadmap for structural reform. The 2005 EU Partnership contains short and medium-term economic and political priorities which need to be addressed in preparing for the opening of negotiations. Among the short-term priorities to be tackled in 1 to 2 years, it short-listed five immediate concerns: (i) improvements in the electoral process; (ii) adoption of the Law on Police; (iii) adoption of constitutional amendments and implementation of measures to improve the judicial system; (iv) implementation of one-stop shop company registration; and (v) implementation of SAA commitments, in particular, in the areas of electronic communications and customs. By end-2006, the EU commission will present a report on Macedonia's progress to the EU Council.

What are the short-term implications of candidate status? There is a widely held, though mistaken, belief that EU candidate status implies an immediate increase in funds from Brussels. In reality, candidate status and changes in how EU assistance will be transmitted after the termination of the CARDS program in end-2006 will require substantial capacity building by the local authorities. For example, the future decentralization of EU assistance under the proposed new Instrument for Pre-Accession (IPA) will require candidate countries to create accredited financial control mechanisms and institutions, especially in the Ministries of Finance, Agriculture, Transportation and Environment. Different levels of accreditation — which will determine access to the five funding sources - are envisaged. Currently, Macedonia would only qualify for access to two of these five funding sources. In addition, these funds will have co-financing requirements of at least 25 percent, which will put added pressure on the central government budget. Nevertheless, if all requirements were met, Macedonia could start to receive some $€ 70$ million annually under IPA (less than $1 \frac{1}{2}$ percent of GDP), about $€ 30$ million more per year than was committed under the existing CARDS program. 


\section{FYR Macedonia-The Problem of Health Sector Arrears}

The Health Insurance Fund (HIF) and 89 state-owned health care institutions (HCIs) constitute the core of FYR Macedonia's health care sector. The HIF manages the operation of the universal and compulsory health care system and provides remuneration for health care services delivered by the HCIs and some private providers. In 2005 HIF expenditures, funded by the payroll tax, co-payments and government transfers, were 5.5 percent of GDP.

In recent years, the health care sector has struggled to meet its social objectives within existing resource constraints. This has resulted in a chronic build-up of payment arrears as well as problems with quality and accessibility of health services and rampant informal outof-pocket payments. According to the World Bank and FAD, factors responsible for arrears accumulation and the inadequate state of the public health system include: (i) conflict of interest and lack of accountability in the HIF and HCIs; (ii) weak financial controls, lack of transparency and inefficient cost structure of the HCIs; (iii) abuse of maternity and sick leave benefits; (iv) insufficient budget financing of publicly mandated preventative programs, and (v) a benefits package de-linked from available health sector resources.

Reflecting concerns over fiscal risks, sustainability and governance of the health care system, the Stand-By Arrangement includes conditionality on non-accumulation of arrears by the HIF as well as commitments by the authorities regarding inventory, audit and repayment of the accumulated arrears. Under the program, the authorities resolved to accumulate no more arrears by the HIF overdue by more than 60 days over and above their stock as of end-December 2004 (performance criterion). The data on HIF arrears, provided to the IMF, cover only payments for drugs and medical supplies procured under the HIF's agreements with private suppliers. ${ }^{1}$ While these centrally procured drugs and other supplies are ultimately utilized and accounted for by the HCIs, payments to suppliers for their procurement are made directly by the HIF.

The HIF reports data on three types of financial obligations arising from procurement of drugs and medical supplies. These include: (i) payments overdue by more than 60 days (program definition), (ii) payments overdue by one day or more, and (iii) HIF debt (including obligations not yet due and payments overdue by one day and more). Table 1 summarizes the evolution of the stock of each of the three types of financial obligations during 2005:

- $\quad$ The stock of payments overdue by more than 60 days increased in January-

September 2005 and then declined slightly in the fourth quarter of the year; however, it remained above the end-2004 level.

\footnotetext{
${ }^{1}$ According to the HIF officials, there are no arrears on any other expenditures (e.g., wages, utility payments) paid directly by the HIF.
} 
- $\quad$ The stock of payments overdue by one day and more also increased between JanuarySeptember 2005, but declined substantially in the fourth quarter of the year while still remaining above the end-2004 level.

- $\quad$ Finally, overall HIF debt increased substantially in the first two quarters of 2005 but then declined in the last two quarters to fall below the end-2004 level.

In the authorities' view, several policy measures implemented in 2005 are responsible for the declining stock of HIF arrears and debt at end-2005: (i) new procedures for competitive international procurement of the positive list drugs with clear definition and limits on quantities purchased under the contracts (which resulted in a net reduction of prices of about 17 percent and estimated annual savings of 0.2 percent of GDP); (ii) privatization of pharmacies in mid-2005, and implementation of new contracts with pharmacies establishing hard budget ceilings; (iii) introduction of new financial reporting requirements for seven largest HCIs in mid-2005. In the authorities' view, further declines will likely be observed in 2006 as all HCIs have been subjected to fixed budget ceilings, monthly transfers from the HIF to HCIs are debited for the cost of drugs and supplies acquired under the centralized procurement program, and access to the sick and maternity benefits is tightened (although the expected gains from the latter measure may be partially offset by increasing HIF responsibility for participants' sick leave from 21 to 60 days).

The increase in the estimated stock of HCIs' own debt could represent a shift of arrears from the HIF to the HCIs. However, due to the HCIs' poor financial reporting, on-going monitoring of their arrears is not possible at this stage. The authorities believe that this concern should be addressed in part by the placement of HIF budget control officers in the top 15 HCIs (new structural benchmark). Further gains should be realized as health sector finances are further rationalized, part of the World Bank's comprehensive reform program. 
FYR Macedonia: Health Sector Debt and Arrears (end of period)

\begin{tabular}{lllllll}
\hline 2004 & \multicolumn{4}{c}{2005} & \\
& $\mathrm{Q} 1$ & $\mathrm{Q} 2$ & $\mathrm{Q} 3$ & $\mathrm{Q} 4$ \\
\hline
\end{tabular}

(in billion denars)

HIF

Debt for procured drugs and supplies of which overdue by one day and more of which overdue by 60 days and more $1 /$

$\begin{array}{lllll}2.7 & 3.0 & 3.2 & 2.9 & 2.3 \\ 1.3 & 1.5 & 1.6 & 1.7 & 1.4 \\ 0.7 & 0.9 & 1.0 & 1.0 & 1.0\end{array}$

Public Health Institutions (HCIs)

Debt 2/

of which from seven largest HCIs

\begin{tabular}{ccccc}
$\ldots$ & 1.4 & 1.4 & 1.6 & 1.8 \\
$\ldots$ & 1.0 & 1.0 & 1.1 & 1.3 \\
& \multicolumn{2}{r}{ (in percent of GDP) } \\
\end{tabular}

HIF

Debt for procured drugs and supplies of which overdue by one day and more of which overdue by 60 days and more $1 /$

$\begin{array}{lllll}1.0 & 1.1 & 1.2 & 1.0 & 0.8 \\ 0.5 & 0.5 & 0.6 & 0.6 & 0.5 \\ 0.3 & 0.3 & 0.4 & 0.4 & 0.4\end{array}$

Public Health Institutions (HCIs)

Debt 2/

of which from seven largest HCIs

$\begin{array}{lllll}\ldots & 0.5 & 0.5 & 0.6 & 0.7 \\ \ldots & 0.4 & 0.4 & 0.4 & 0.5\end{array}$

Memorandum item

GDP (in billion denars)

Source: Ministry of Finance.

$1 /$ Ceiling on this item is a quantitative performance criterion under the program. The value of the end-2004 stock reported in the original program document was 1.710 billion denars: the correct figure is 0.67 billion denars. According to the authorities, the reported figure was an (incorrectly) estimated value of HIF arrears overdue by one day and more.

2/ Debt not explicitly guaranteed by the HIF, based on montly financial reports by seven largest HCIs introduced in 2005, and Ministry of Finance estimates for other HCIs. 


\section{FYR Macedonia-Fund Relations}

(as of February 28, 2006)

I. Membership Status:

II. General Resources Account:

Quota

Fund holdings of currency

Reserve Position

III. SDR Department:

Net cumulative allocation

Holdings

IV. Outstanding Purchases and

Loans:

Extended Arrangements

PRGF Arrangements

Stand-By Arrangements
Joined 12/14/92; Article VIII

\author{
$\underline{\text { SDR Million }}$ \\ 68.90 \\ 99.76 \\ 0.00
}

$\frac{\text { SDR Million }}{8.38}$

$\underline{\text { SDR Million }}$

0.86

12.63

30.00 \begin{tabular}{r} 
Percent of Quota \\
\hline 100.00 \\
144.79 \\
0.00
\end{tabular}

Percent of Allocation

100.00

1.87

$\underline{\text { Percent of Quota }}$

1.25

18.34

43.54

V. Latest Financial Arrangements:

$\begin{array}{lcccc}\text { Type } & \begin{array}{c}\text { Approval } \\ \text { Date }\end{array} & \begin{array}{c}\text { Expiration } \\ \text { Date }\end{array} & \begin{array}{c}\text { Amount Approved } \\ \text { (SDR Million) }\end{array} & \begin{array}{c}\text { Amount Drawn } \\ \text { (SDR Million) }\end{array} \\ \text { Stand-By } & 08 / 31 / 2005 & 08 / 30 / 2008 & 51.68 & \\ \text { Stand-By } & 04 / 30 / 2003 & 08 / 15 / 2004 & 20.00 & 10.50 \\ \text { EFF } & 11 / 29 / 2000 & 11 / 22 / 2001 & 24.12 & 20.00 \\ & & & & 1.15\end{array}$

VI. Projected Payments to the Fund (Expectations Basis): ${ }^{1}$

(SDR million; based on existing use of resources and present holdings of SDRs):

\begin{tabular}{lrrrrr} 
& \multicolumn{7}{c}{ Forthcoming } \\
\cline { 2 - 6 } & 2006 & 2007 & 2008 & 2009 & 2010 \\
Principal & 9.09 & 20.09 & 9.60 & 4.38 & 0.34 \\
Charges/Interest & $\underline{1.33}$ & $\underline{1.33}$ & $\underline{0.73}$ & $\underline{0.40}$ & $\underline{0.28}$ \\
Total & $\underline{10.42}$ & $\underline{21.42}$ & $\underline{10.33}$ & $\underline{4.78}$ & $\underline{0.63}$
\end{tabular}

\footnotetext{
${ }^{1}$ This schedule presents all currently scheduled payments to the IMF, including repayment expectations and repayment obligations. The IMF Executive Board can extend repayment expectations (within predetermined limits) upon request by the debtor country if its external payments position is not strong enough to meet the expectations without undue hardship or risk.
} 


\section{Projected Payments to the Fund (Obligations Basis): ${ }^{2}$}

(SDR million; based on existing use of resources and present holdings of SDRs):

\begin{tabular}{lrrrrr} 
& \multicolumn{6}{c}{ Forthcoming } \\
\cline { 2 - 6 } & 2006 & 2007 & 2008 & 2009 & 2010 \\
Principal & 6.49 & 12.08 & 11.66 & 8.79 & 4.47 \\
Charges/Interest & $\underline{1.33}$ & $\underline{1.61}$ & $\underline{1.21}$ & $\underline{0.73}$ & $\underline{0.40}$ \\
Total & $\underline{7.83}$ & $\underline{13.70}$ & $\underline{12.87}$ & $\underline{9.52}$ & $\underline{4.87}$
\end{tabular}

\section{Safeguards Assessments:}

An update was completed on February 28, 2006 with respect to the current StandBy Arrangement. The previous assessment was completed in April 2003. The update found that the NBRM had taken steps to strengthen its safeguards framework and recommendations from the earlier assessment had been implemented. Notwithstanding this progress, the report made recommendations in the reporting and audit areas, including: (i) review by the NBRM internal audit function of processes for compiling monetary data reported to the Fund under the program; and (ii) completion of annual external audits on a timely basis as prescribed by the central bank law.

\section{Exchange Rate Arrangement:}

The currency of the FYR Macedonia is the denar. The FYR Macedonia maintains a managed floating exchange rate system with a de facto peg to the Euro.

Households can transact only through commercial banks or through foreign exchange bureaus that act as agents of banks; enterprises can transact through the banking system. The reserve requirement on all foreign currency deposits is set at 10 percent.

At end-January 2005, the official exchange rate was 50.83 denars per U.S. dollar and 61.41 denars per euro. The FYR Macedonia has accepted the obligations of Article VIII, Sections 2, 3, and 4 with effect from June 19, 1998. The FYR Macedonia maintains an exchange restriction subject to the Fund's approval under Article VIII, Section 2(a) arising from restrictions imposed on the transferability of proceeds from current international transactions contained in former frozen foreign currency saving deposits. The retention of this restriction was approved by the

\footnotetext{
2 This schedule is not the currently applicable schedule of payments to the IMF. Rather, the schedule presents all payments to the IMF under the illustrative assumption that repayment expectations-except for SRF repayment expectations-would be extended to their respective obligation dates by the IMF Executive Board upon request of the debtor country. SRF repayments are shown on their current expectation dates, unless already converted to an obligation date by the IMF Executive Board.
} 
Board on June 27, 2005 until April 30, 2006 or the completion of the next Article IV consultation, whichever is earlier.

IX. Article IV Consultations:

The first consultation with the FYR Macedonia was concluded in August 1993. The last consultation was concluded on April 30, 2003. The FYR Macedonia is on the standard consultation cycle.

X. Technical Assistance (since 2001):

\section{Purpose}

Banking Reform

Credit Growth

National Accounts

BOP Statistics

Tax Administration

Reserve Management

Monetary Statistics

Debt management

National Accounts

Debt Management

Fiscal Decentralization

Public Expenditure Management

Monetary Operations and Payment System

Balance of Payments Statistics

Tax Policy

Development of a Treasury System

Resident Experts

Monetary Policies

Value-Added Tax

$\begin{array}{ll}\text { Department } & \text { Date } \\ \text { MFD } & \text { November } 2005 \\ \text { MFD } & \text { October } 2005 \\ \text { STA } & \text { July } 2005 \\ \text { STA } & \text { July } 2005 \\ \text { FAD } & \text { May } 2005 \\ \text { MFD } & \text { May } 2005 \\ \text { STA } & \text { April } 2005 \\ \text { FAD } & \text { October } 2004\end{array}$

STA

May 2004, October 2004

FAD

March 2004

FAD

FAD

September 2003

March 2002

May 2003

MFD

November-December 2002 April 2004

STA

October 2002

FAD

December 2001

FAD

November 2001

MFD

October 2004-April 2005

FAD 
XI. FSAP Participation and ROSCs (since 2003):

Purpose

Fiscal ROSC

Data ROSC

FSAP
Department

FAD

STA

MFD/WB
Date

February 2005

February 2004

May 2003 and June 2003

XII. Resident Representative:

The Fund has had a resident representative in Skopje since 1995. Mr. Kevin Ross has held this position since May 2003. 


\section{FYR Macedonia: IMF-World Bank Relations Annex (Prepared by the World Bank)}

\section{A. Partnership in FYR Macedonia's Development Strategy}

1. FYR Macedonia has made considerable progress since independence in 1991, with support from the international community. While risks still remain, the relatively calm external and internal environment presents FYR Macedonia with perhaps the first significant window of opportunity since independence to focus on strengthening growth and employment opportunities. This follows the resolution of regional conflicts that took place through much of the 1990s, especially the cessation of hostilities in neighboring Kosovo, which particularly affected FYR Macedonia. Similarly, the Ohrid Framework Agreement of late 2001 has brought a reasonable measure of stability to the country, despite continuing isolated incidents. FYR Macedonia's progress is reflected perhaps most prominently in the agreement with the European Union (EU) on a Stabilization and Association Agreement, as well as FYR Macedonia's recent application to begin negotiations on EU membership.

2. Macro-economic stability has been largely maintained since the mid-1990s, and been further strengthened since 2002. Fiscal discipline and the peg to the Euro have helped to bring inflation close to zero, and resulted in Government spending falling as a proportion of GDP to a level significantly lower than most of the other former Yugoslav republics.

3. Nevertheless, despite the recovery of annual growth rates of 4 percent, unemployment remains high and of serious concern. Growth remains constrained by structural impediments. Further reform to improve competitiveness will be crucial to attract the investment needed to encourage stronger growth and to provide employment opportunities.

\section{B. World Bank Supported Reform}

4. Since FYR Macedonia joined the World Bank in 1993, 33 loans have been approved with a total value of approximately US\$754 million. About half of all lending has been on concessional IDA terms. FYR Macedonia graduated fully from IDA in 2003 reflecting improved economic performance and credit-worthiness. All new lending since 2003 has been on IBRD terms.

5. The World Bank's current program of assistance to FYR Macedonia is outlined in a Country Assistance Strategy discussed by the Board in September 2003. Reflecting Government priorities, the CAS outlines three broad areas of support: (i) promoting the efficient management of public resources and tackling corruption; (ii) promoting the creation of jobs through sustainable private sector led growth; and (iii) promoting social cohesion, building human capital, and protecting the most vulnerable. The CAS envisages a series of multi-sectoral development policy loans, supported by specific investment operations to build capacity to support priority reform areas. The CAS also provides for total financing in a 
high case lending scenario of up to US\$165 million over three years. FYR Macedonia has qualified for such a high case lending scenario since the CAS was discussed by the Board.

6. World Bank operations in the past few years have focused primarily on supporting Macedonian Government efforts to strengthen public sector management and governance. A US\$15 million Public Sector Management Adjustment Credit (PSMAC) approved in 2002, and a recently completed US\$30 million Public Sector Management Adjustment Loan II (PSMAL II) have emphasized:

(i) improving governance of the health sector, particularly through reform of the Health Insurance Fund and international tendering for very significant pharmaceuticals contracts (which has resulted in savings to the Government of over US\$10 million per annum);

(ii) strengthening overall budgetary management, especially though the consolidation of extra-budgetary funds within the Treasury Single Account; and

(iii) civil service reform, including the greater application of the merit principle in hiring and promotion decisions, and associated wage decompression to encourage retention of senior and experienced staff.

7. While maintaining involvement in key elements of the governance agenda, particularly health sector financing reform, the Bank's policy dialogue with the Government is increasingly shifting to structural economic reform to improve the business environment and promote growth and employment. Bank support for Macedonian Government reform efforts will be centered on a series of Programmatic Development Policy Loans (PDPLs), the first of which was approved by the Board in October 2005, shortly after IMF Board approval of the proposed current Stand-By Arrangement (SBA). In terms of strengthening the overall business and investment climate, the PDPLs support Government efforts to undertake judicial reform, labor market reform, and strengthened financial sector regulation and supervision. Efforts to further strengthen public sector governance include an emphasis on further reform to improve the transparency of the critical health sector, building the capacity of the civil service to permit more effective strategic prioritization, and support for the decentralization program being conducted under the umbrella of the Ohrid Framework Agreement.

8. Development policy lending has been, and will continue to be, supported by a series of specific investments to build capacity to implement priority reforms. On the governance and public administration side, a Health Sector Management Improvement project will continue to provide technical assistance and investment support to the broader health sector reform program; a Social Protection project will continue to support reform in this area, including the introduction of a second pillar pension system; and an Education project will continue to assist Government efforts to improve access and introduce stronger performance and equity measures in primary and secondary education financing. On the investment 
climate side, a Business Environment Reform and Institutional Strengthening (BERIS) project approved in June 2005 will concentrate on building capacity to improve business entry, operations, and exit; as well as enhancing the competitiveness of the enterprise sector; and a Real Estate Cadastre and Registration project approved in early 2005 is intended to strengthen land markets and the use of real property as collateral for business investment by providing more secure title. A Legal and Judicial Reform project currently under preparation is planned to be presented to the Board in early 2006 to support critical reforms in this area. Adjustment and investment lending has also been backed up by a comprehensive program of analytical work.

\section{IMF - World Bank Collaboration in Specific Areas}

9. World Bank and IMF engagement in FYR Macedonia in recent years has been marked by a spirit of collaboration and cooperation between the two institutions, and with the Government. Synergies between the proposed Bank and IMF programs over the next three years reflect a strong degree of consensus between both institutions and the Government in regard to reform priorities. Especially given the broad range of structural reform areas in which the Bank and the Fund will both be engaged, however, it will be critical that close coordination is maintained in order to ensure that the SBA and the Bank program are mutually reinforcing.

\section{Improving the Investment Climate}

10. There is broad consensus that judicial reform is central to improving the business environment in FYR Macedonia. As recognized in the Government's December 2004 Strategy on the Reform of the Judicial Sector, comprehensive judicial reform is especially urgent to firmly establish the efficient, effective, and fair enforcement of creditor, contract, and property rights. The Bank's Doing Business report has also highlighted the time and cost of enforcing contracts and conducting bankruptcy procedures as particular constraints in FYR Macedonia. IMF SBA benchmarks to analyze and budget for the fiscal effects of judicial reform, enact amendments to the Bankruptcy Law, amend the Law on Misdemeanors to allow administrative bodies to impose sanctions without prior court involvement should complement Bank supported reform efforts. Under the PDPL and the proposed Legal and Judicial Reform project, the Bank will focus on: reducing backlog and delays in court proceedings by 25 percent; improve the enforcement of court judgments; improve the regulatory and implementation framework for bankruptcy cases including the development of a profession of bankruptcy trustees; and increase the speed, transparency, and fairness of administrative decisions. Ultimately, institution building to support the legislative reform agenda will be crucial, and is likely to take several years.

11. Support for labor market reform will also require close coordination. A very rigid legislative framework governing labor relations has contributed to a stagnant formal labor market, unemployment rates among the highest among transition economies, limited opportunities for new entrants to the labor market, and a large informal sector. The recently 
adopted Law on Labor Relations - a prior action for the Fund SBA-will eliminate the most burdensome features of the old law and, over time encourage growth, investment, and a gradual shift in employment from the informal sector to the formal sector, with a concomitant strengthening of workers' rights. Further efforts to strengthen labor market flexibility, including the implementation of the new legislative framework, the establishment of alternative dispute resolution mechanisms, and a renegotiation of collective agreements are expected to be supported by the three PDPL operations.

12. Judicial and labor market reforms are being complemented by a range of other measures to strengthen the framework for business activity. The enactment and implementation of a new Business Registration Law and associated regulations will be critical to reducing the relatively high costs and time of business entry - with the time required for registration currently exceeding the regional average. The Government is also establishing a permanent body to oversee regulatory reform, including the streamlining of business licensing, permits and inspections. These continuing reforms will be supported over the next few years by the Bank's PDPL operations as well as the BERIS project. Further actions to implement corporate governance and accounting and auditing reports on standards and codes (ROSCs) will also be required, including amendments to the Company Law and Securities Law, and the passage of a new Audit Law. Efforts by the Bank to support the capacity of the National Bank (NBRM) to supervise and regulate the banking sector, and to strengthen compliance with anti-money laundering and counter-terrorist financing requirements, will also need close coordination with the IMF, and the SBA also includes benchmarks on the strengthening of risk-based supervision by the NBRM.

\section{Public Sector Transparency and Governance}

13. Reform of health sector financing will be a key element of both the Bank and IMF programs. Health sector financing makes up 15 percent of Government expenditure and has historically been an area with significant public financial management risks associated with both pharmaceutical procurement and the less than fully transparent operation of the Health Insurance Fund (HIF). As noted in the SBA documentation, implementation of health sector reform will be a litmus test for the authorities' commitment to fight corruption. Prior actions and performance criteria in the SBA requiring submission to Parliament of relevant legislation to tighten the selection of the HIF Board, implement more transparent budget procedures, and introduce binding budget ceilings for the largest public health institutions will be reinforced through existing and proposed Bank programs, which will also support efforts to further prioritize spending, improve the cost-effectiveness of health interventions, and further strengthen mechanisms for pharmaceutical procurement.

14. Continued collaboration between the Bank and the IMF will be necessary in regard to the consolidation and rationalization of social insurance contributions with the collection of personal income tax. The Bank supports Government efforts, with IMF assistance, to merge collection over time. At the implementation level, however, rationalization and consolidation of social insurance contributions will need to continue to be coordinated with 
Bank efforts to support Government reform of the social protection system, including the introduction of a second pillar pension scheme.

15. Bank support for civil service reform, including strengthening institutional arrangements for strategic prioritization, should complement IMF efforts to improve fiscal and budget management. Extending civil service reform to the majority of Government employees who are not civil servants will further strengthen meritocratic principles and the professionalism of the public sector. Nevertheless, any potential wage decompression among this group - although not scheduled to begin immediately - will require close coordination with the Fund to ensure that fiscal targets, including ceilings on the wage bill, are adhered to. This will also need to occur within the framework of the Ohrid Framework Agreement, and the associated provisions for the representation of minorities. Similarly, IMF benchmarks regarding the completion and implementation of a functional analysis of line Ministries have been set in close coordination with the Bank, as well as other bilateral and multilateral donors active in public sector reform.

16. The Government has made substantial progress in enacting the legislative framework for decentralization, including passage of the controversial Law on Territorial Reorganization, and adopting a formula for the distribution of VAT revenues between the national Government and the various municipalities. Nevertheless, before municipalities assume responsibility for child care and elderly functions under the first phase of decentralization, a plan for resolving municipal arrears still remains to be agreed. Considerable capacity strengthening at the municipal level will also be required if the second phase of decentralization, including the provision of block grants to municipalities to fund schools, is to be implemented successfully and for service standards to be maintained. This will clearly require close coordination between the Government, the IMF, the bank and other relevant donors.

\section{Summary}

17. FYR Macedonia has made considerable progress in macro-economic management and improving the transparency and operations of the public sector. Although continuing governance and macro-economic challenges remain, there is broad consensus that a stronger focus on structural reform will be required to overcome key impediments to growth and employment. This is reflected in both the IMF and Bank programs. The strong similarities between aspects of the IMF SBA and the Bank's proposed adjustment and investment lending program have considerable potential to generate synergies and complementarities. This will, however, require continuing strong collaboration between the Macedonian Government, the Bank and the IMF. 
Skopje, Macedonia March 31, 2006

Mr. Rodrigo de Rato

Managing Director

International Monetary Fund

Washington, D.C. 20431

U.S.A.

Dear Mr. de Rato,

1. Economic performance under the Stand-By Arrangement (SBA) has been strong. After growing by 4.1 percent in 2004, the economy expanded at a 3.9 percent annualized rate in the first 3 quarters of 2005. Most importantly, employment growth has taken off, increasing by about 6 percent year-on-year in the third quarter of 2005 . As in the recent past, average inflation in 2005 has remained muted at 0.5 percent. Despite higher oil prices, the trade balance has improved due to expanding exports and lower growth in consumption goods imports. With private transfers increasing sharply, the current account deficit has also narrowed substantially, to less than $1 \frac{1}{2}$ percent of GDP. These positive developments, along with our achievement of EU candidate status, the upgrade in our credit rating, and the successful launch of our inaugural Eurobond, confirm our economic program's success.

2. To build on these achievements, we are deepening and advancing the economic reform agenda. Therefore, in addition to continuing with the macroeconomic policies that have yielded these impressive results, we have formulated a comprehensive agenda for structural reform in 2006. Our strong commitment to converge with EU standards and to opening negotiations for EU accession as soon as possible guides our reforms. The reforms described in this letter aim to maintain prudent macro policies, control health care spending, move the banking sector further in line with EU standards and best international practice, and facilitate private sector development and investment.

3. We have made good progress in implementing our economic program:

- We achieved the program's entire set of fiscal and monetary targets for end2005 (Table 1). The 2005 budget ended the year in surplus, exceeding the program target by more than 1 percent of GDP. This prudent fiscal policy has played a key role in reducing the current account deficit, while improved financial market confidence has raised the demand for denar denominated assets, creating substantial capital inflows. As a result, the NIR target was exceeded by about $€ 150$ million, with roughly half of all foreign exchange inflows sterilized. This has allowed the NBRM to lower interest rates by 300 basis points since mid-2005. 
- We have also introduced a considerable number of structural reforms, in line with the benchmarks under the program (Table 2). All public health institutions have prepared budgets for 2006 approved by the Ministry of Health in line with HIF transfers which have become binding ceilings, meeting a key end-December performance criterion. The one-stop shop registration system is in place and already easing the cost of doing business. Most importantly, we have amended the constitution to allow for comprehensive judicial reform. The Public Revenue Office (PRO) has improved its organizational structure and preparations for the Large Taxpayer Office (LTO) are on track. We also started to tender for sale the residual state shares in commercial banks. In the monetary sphere, we have started the monetary issuance of treasury bills and repo operations at the NBRM. Finally, we completed strategic plans and functional analyses for all ministries, which will improve our 2007 budget process.

4. Though some of our reforms have been delayed, we are now addressing these:

- We request waivers of non-observance for two structural performance criteria for December 31, 2005 that were missed. We were unable to fill key positions at the PRO by the end of last year as its organizational restructuring process took longer than expected. However, we have now filled these positions. Our decision to prepare a more comprehensive reform in cooperation with the Fund and the World Bank meant that we were also unable to submit the new Banking Law to Parliament by end-2005.

- We request a waiver of applicability for all quantitative performance criteria as of end-March 2006 due to data unavailability.

- We request a waiver of non-observance for the end-December 2005 quantitative performance criterion on the arrears of the Health Insurance Fund (HIF). An audit of total health sector obligations indicated that HIF arrears increased in 2005, though there are signs that these started to fall at the end of the year. We are taking measures to progressively reduce the stock of HIF arrears to their end-2004 level.

- Though a few structural benchmarks were delayed, we have now implemented all but one of these. Instead of simply passing amendments, we prepared with the World Bank a whole new bankruptcy law, which Parliament passed in March. Again working with the World Bank, the NBRM adopted a Supervisory Development Plan. However, though we have prepared the 2006 court budget, preparing an analysis of the fiscal costs of judicial reform is taking more time.

5. Against this favorable backdrop, we request the completion of the First Review. We believe that the policies described in this letter-which updates and supplements the policies laid out in our Letter of Intent of August 16, 2005-are adequate to achieve the objectives of our economic program. Most importantly, we believe this program will help us 
achieve our objective of EU accession. Nevertheless, we stand ready to take any further measures to keep our program on track. We will remain in close consultation with the Fund, in accordance with the Fund's policies on such consultations. We will provide the Fund with such information as it requests on policy implementation and achievement of program objectives. The forthcoming Second Review, scheduled for early September 2006, will provide an opportunity to assess progress in program implementation and reach understandings on any measures that may be needed to reach the program's objectives.

6. We reaffirm our intention not to make the purchase under the SBA that will become available upon observance of its performance criteria and completion of its reviews. To smooth our debt service profile, we also request to make all outstanding repurchases to the Fund falling due through end-2007 (equivalent to SDR 13,386,669) on an obligations schedule.

\section{Economic policies for 2006}

FYR Macedonia: Macroeconomic Framework, 2004-2006

\begin{tabular}{|c|c|c|c|c|c|}
\hline & \multirow{2}{*}{$\begin{array}{l}2004 \\
\text { Prel. }\end{array}$} & \multicolumn{2}{|c|}{2005} & \multicolumn{2}{|c|}{2006} \\
\hline & & $\mathrm{SR}$ & Prel. & SR & Proj. \\
\hline Real GDP growth & 4.1 & 3.7 & 4.0 & 4.0 & 4.0 \\
\hline Inflation (average) & -0.3 & 1.2 & 0.5 & 1.8 & 1.8 \\
\hline Current account balance (in percent of GDP) & -7.7 & -6.5 & -1.4 & -5.2 & -3.7 \\
\hline excluding official transfers & -9.0 & -7.8 & -2.5 & -6.1 & -4.9 \\
\hline Central government deficit & 0.4 & -0.8 & 0.3 & -0.6 & -0.6 \\
\hline Broad money growth rate & 16.1 & 17.7 & 14.9 & 18.4 & 19.1 \\
\hline Private sector credit growth rate & 25.0 & 22.7 & 20.5 & 19.1 & 22.8 \\
\hline
\end{tabular}

Source: MOF, NBRM, and Fund staff compilations.

7. The improvement in economic performance is set to continue in 2006. All indicators suggest that we comfortably met our 2005 real GDP growth target of 3.8 percent. With lower interest rates likely to strengthen domestic demand, we expect growth to rise to around 4 percent in 2006. Higher energy prices and an increase in cigarette taxes should cause inflation to pick up to around 2 percent. Last year's agreement on moderate increases in public sector wages should keep private sector wage inflation in check. With domestic demand increasing, and private transfers set to stabilize, the current account deficit is likely to widen slightly. 
8. In light of the better than expected outcome on reserve accumulation, we have set slightly more ambitious monetary targets than had been envisaged under the original program (Table 1). From end-June the net international reserve and net domestic asset targets will be raised to lock in roughly two-thirds of our end-2005 overperformance in reserves, to prevent this from leading to excessive monetary expansion. This should increase international reserves to slightly more than four months of imports. We have also increased modestly the size of the privatization adjuster given uncertainties over the timing and size of these receipts. If capital inflows and over-performance of foreign reserve accumulation continues, we will maintain our prudent monetary policy.

\section{Fiscal policy and public sector reforms}

9. We are committed to deliver on our 2006 fiscal deficit target of 0.6 percent of GDP. Though still prudent, the program target represents a fiscal easing of around 1 percent of GDP compared to the 2005 outcome. Current expenditures are held roughly constant in real terms, so that they fall as a share of GDP, reflecting tight wage policy and lower transfers. Extra fiscal costs related to higher than expected enrollment in the second pillar pension are offset by a low estimate in our budgeted telecom dividend. Nevertheless, we stand ready to take measures later in the year should this threaten our deficit target. With parliamentary elections taking place in 2006, we are determined to maintain budget discipline.

10. Although health sector obligations and arrears have increased since end-2004, there are signs that these stabilized in the second half of 2005 :

- As of end-2005, Health Insurance Fund (HIF) arrears measured using the program definition (obligations that are due but not paid by more than sixty days) were 317 million denars above their end-2004 level, breaching the performance criterion. New measurement, however, shows that the end-2004 stock of arrears (using the program definition) was 1,040 million denars lower than reported in the program document. On a flow basis, there was an improvement in the last three months of 2005, as total HIF obligations fell by 545 million denars, while arrears measured on the program definition fell by 56 million.

- Developments in overall health sector debts are harder to interpret, but here too there are signs that, with the introduction of international tendering and receipt of payments from the pension fund, these may have stabilized. Preliminary and unaudited results suggest that these increased during the first nine months of the year, before falling in the last quarter of 2005 . We are still working to validate and clean up the database. With the submission of HCI final accounts to the HIF, we will soon have a clear picture of total health sector obligations and arrears. 
11. Immediate action will be taken to ensure that total health sector arrears are controlled in 2006, with a view towards building a full-fledged treasury system for the health sector.

- Starting in 2006, public health care institutions (HCIs) are operating within hard budget ceilings, which are based on their actual expenditure profile in 20032005. The Health Insurance Fund (HIF) will make equal ( $1 / 12^{\text {th }}$ seasonally adjusted) monthly transfers of the annual allocation to each HCI with the cost of drugs and supplies procured directly by HIF tender debited from the monthly allocations. The HIF has also started to publish monthly budget execution reports which include transfers to the HCIs (structural benchmark).

- We will place a budget control officer by June 30, 2006 in each of the top 15 HCIs according to debt outstanding (new structural benchmark). Until June 2007 these budget control officers will be HIF staff paid by HIF and will apply standard ex-ante controls over commitments and payments in HCI budgets. The budget control officers will report to HIF and will keep the HCI Director fully informed. The budget control officers are also expected to strengthen HCI financial management.

- The budget control officers will be required to report monthly to HIF, MOF and MOH on the status of the debt stock and the age of arrears of the HCI and the changes since the prior month. This will use the format employed by the HIF in its regular monthly report on debt and arrears by category of debt and by institution. The individual monthly debt and arrears reports will be consolidated by HIF in the regular monthly format and posted on its web site in addition to the individual and consolidated financial statements of the HCIs.

- A budget officer from the MOF staff, reporting to the Minister of Finance and the Minister of Health, will be established in the HIF with responsibility for exercising all ex ante controls over commitments and expenditures against the HIF budget economic categories by end-September (new structural benchmark).

- To mitigate risks of HCIs building up arrears despite fixed budget ceilings, the Minister of Health will strengthen accountability of HCI Directors for financial performance by rigorously exercising his right under existing legislation of dismissal in the case of imprudent use of funds.

- The HIF Board will review the progress of the HIF and the HCIs in managing their stock of debt and arrears as a regular part of their monthly financial oversight activities.

- $\quad$ Audit procedures for HCIs will be clarified. The 7 pilot HCIs (which include the 5 largest HCIs) will be audited by the State Audit Office once every 3 years. 
- In light of these improvements in control, we propose to convert the performance criterion on HIF arrears to an indicative target.

12. We are making contingent plans to increase resources to the HIF. Surplus revenues from a new five denars a pack tax on tobacco in 2006 will potentially be made available for reallocation to the HIF in a supplementary budget; these will be used only to finance the thirteen existing national health programs. However, this additional allocation will be contingent on realized revenues exceeding the VAT and excise tax revenues targeted in the 2006 budget.

13. We have made considerable progress in implementing our broad-based reform of tax administration. In tandem with our macro-fiscal objectives, we aim to improve the quality of our fiscal management. In this regard, with technical support from the Netherlands and the Fund's Fiscal Affairs Department, we have embarked on a 3-year program to strengthen the effectiveness and efficiency of revenue administration, including collection of social contributions, to boost revenues and support essential government expenditures:

- A new Law on Tax Administration Procedures, which expands taxpayer protections and broadens PRO's authority to levy fines and seize assets without court intervention, was passed by Parliament and becomes effective on April 1.

- We are using technical assistance to improve arrears collection, taxpayer registration, audit, performance measurement, and base harmonization for personal income tax and social contribution collections.

- The PRO has redesigned its organizational chart along functional lines. The PRO anticipates filling the positions most critical to the reforms by end-March, a three month delay compared to the end-December performance criterion.

- $\quad$ Preparations for establishing a Large Tax Payer Office (LTO) at the PRO and Large Contributor Office (LCO) at the Pension Fund by July are on track. The 100 largest taxpayers and contributors have been identified, organizational charts completed, and office space and computer equipment for the LTO have been secured. We expect to open the LTO and LCO on July 1, 2006; their establishment by endJuly 2006 is a structural performance criterion.

- Given complexities in implementation, we are modifying our plan to approve a harmonized PIT and social contributions tax base by June 2006. We will now proceed in two phases. The first phase, to be completed by year-end, will harmonize the bases for social contributions; the second will harmonize this with the base for personal income tax.

- In support of the first phase, by end-June we will prepare a strategy paper (agreed with the Fund) identifying key parameters for harmonization of social contribution bases (new structural benchmark). This will include a single and 
simple minimum wage base, use of gross wages in rate calculations, common definitions of employer and employee, common lists of beneficiaries and a common definition of employment income. Consistent with this strategy paper, we will submit legislation harmonizing the bases for social contributions to Parliament by endSeptember (new structural benchmark). Implementation of the new legislation at the start of 2007 will be set as a new performance criterion during the Second Review.

- We plan to fully harmonize PIT and social contributions by end-2007. A final decision on the possible inclusion of allowances in taxable income, including the abolition of the minimum base, will be guided by future Fund technical assistance. By June 2007 we will prepare a strategy (structural benchmark); implementation by the start of 2008 will be set at a subsequent review as a structural performance criterion.

\section{We intend to further improve the quality and efficiency of our fiscal spending} and control mechanisms:

- $\quad$ The World Bank began a Public Expenditure Review (PER) in February, and we expect to receive a preliminary study on short-term expenditure reform by late summer. These preliminary findings will help guide our 2007 budget discussions, and may be included as conditionality in the program.

- We will continue the work on the systematization of line ministries. In line with the first review's structural benchmark, we have finalized a functional analysis for all line ministries and prepared strategic plans on how to implement its findings. However, only the Ministry of Finance and the Ministry of Environment provided high quality strategic plans on time for the 2006 budget process. With the support of DFID, other line ministries have been improving their strategic plans. At a minimum, the Ministry of Economy's and the Ministry of Labor and Social Protection's strategic plans will be ready to be incorporated in the 2007 budget process (reset structural benchmark).

- We will start the regular monitoring and reporting exercises and pre-accession fiscal surveillance required for $\mathbf{E} \mathbf{U}$ membership. We have already been included in the Candidate Countries' Economies Quarterly (CCEQ) exercise, starting from the last quarter of 2005. In 2007 we will start regular participation in the fiscal notification exercise, where we will present certain fiscal data in accordance with ESA95 standards. In the meantime we will start consultations with EUROSTAT and submit preliminary fiscal deficit and government debt data using our current methodology. We will begin regular reporting to the Pre-Accession Fiscal Surveillance exercise, and participate in EU fiscal subcommittees. We plan to request technical assistance from the IMF to move to GFS 2001 as an intermediate step before moving to ESA95 standards. 
- We have established two new units required for the decentralized management of EU funds: a National Fund Unit within the Treasury Department and a CFCU Unit within the Budget Department that will be fully staffed by end-April.

- We will start to report budget execution data at the general government level by April 2006.

15. We have substantially upgraded the debt management function at the Ministry of Finance. The public debt department—which took an active role in the successful Eurobond issue - already has front and back office staff, and will be fully staffed once the middle office function is established by end-2006. The department has finished work on a debt management strategy, which defines the government's public sector borrowing policy, setting three-year targets and including portfolio diversification, risk, and term structure objectives. In order to meet these objectives, we will purchase debt management software that meets the specifications recommended by EAR and the IMF by end- 2006 .

\section{Monetary and financial sector reform policies}

16. The NBRM will continue to support our economic program by maintaining a pegged exchange rate regime backed by adequate international reserves. The NBRM's monetary program for 2006 is consistent with average broad money growth of about 20 percent, in line with a gradual decline in velocity. The degree of euroization is expected to fall slightly as demand for denar assets remains strong. Gross official reserves are projected to end 2006 at about $€ 1.3$ billion, increasing reserve cover to just over 4 months of the following year's imports of goods and non-factor services. We expect the sizable inflows of capital experienced in 2005 will continue in 2006, reflecting confidence in our macroeconomic policies and increased real currency demand. To ensure the continued success of the pegged exchange rate, we stand ready to continue our policy of sterilizing inflows through the issuance of central bank bills and treasury bills for monetary policy purposes.

17. To ensure a prudent monetary policy stance in 2006, we will lock in two-thirds of our 2005 monetary over-performance, relative to the existing program target. Recent declines in interest rates on central bank bills are expected to raise demand for private sector (especially denar) credit, which we now project to grow at more than 20 percent in 2006. Together with continued capital inflows, this is expected to contribute to similarly robust broad money growth. To prevent the increase in reserves from resulting in excessive monetary expansion we will raise the NIR target from end-June 2006 (and tighten the NDA target accordingly) to lock-in two-thirds of the projected over-performance; at the same time, we are increasing the privatization adjuster by $€ 50$ million in light of uncertainties over the precise timing and size of privatization receipts this year. As a result, we expect to sterilize an additional 3 billion denars on average throughout 2006 . 
18. The government remains committed to safeguarding Central Bank independence and strengthening its financial soundness:

- $\quad$ By end-June, we will amend the NBRM Law and other legislation to: (i) let the NBRM retain 70 percent of its profits when general reserves are below the statutory limit, and then 15 percent after that; (ii) limit the right of appeal to the NBRM Council to internal NBRM decisions, appeals of external decisions will go directly to the courts; and (iii) protect the governor's decisions in the areas of bank licensing, receivership and bankruptcy from reversal by the courts, though successful appeals still might seek financial compensation. This strengthens the reforms envisaged in the existing structural benchmark in the program.

- In parallel with our revision of the Banking Law, we will seek other legal amendments to limit the reversal of the governor's decisions in matters of financial regulation and supervision, and to ensure that court review is limited to ensuring the procedural aspects were met. The goal is to bring financial regulation and supervision more closely in line with EU standards and best international practice. An agreed draft should be prepared by end-September and submitted to Parliament by end-December.

- We will submit a revised National Bank Law, consistent with EU standards, next year.

19. We are preparing a comprehensive revision of the legal framework to improve the soundness of the banking system. After consultations between the Ministry of Finance and the NBRM, we produced a new draft of the Banking Law that addresses a number of important areas, including governance issues, clarification of the roles of the Audit and Risk Management Committees, accuracy of financial reporting, increased capital requirements, and enhanced licensing requirements. However, we have now decided to include additional provisions to bring the Law closer in line with EU standards and international best practice, and to engage in more extensive consultations with the banking community. As a result, the end-December performance criterion on submitting a new law to Parliament was missed. To assist us in completing the new and more comprehensive law, we have requested further technical assistance from the Fund. The Ministry of Finance and the NBRM will complete a draft agreed with the staff (focused on, inter alia, bank governance, consolidated supervision, the framework for corrective actions and resolution of weak or insolvent banks, connected lending and harmonization with EU legislation) by end-September 2006 (structural benchmark). Submission of the new law to Parliament by end-December 2006 will be set as a performance criterion at the Second Review. We will also review the Law on Deposit Insurance to make it consistent with the new Banking Law, including setting an appropriate target for Deposit Insurance Fund reserves and ensuring that insurance can be paid promptly.

20. We have started to strengthen banking supervision in the NBRM. We agreed on a Supervisory Development Plan (SDP) with the World Bank in January, completing our structural benchmark with a one-month delay. Besides strengthening supervisory activities, 
the plan will help the NBRM migrate to a more risk based, anticipatory approach to banking supervision. To facilitate implementation and evolution of the plan, we are engaging an MFD resident advisor who should be in place by May. Together with the SDP, the advisor will be guided by the World Bank's Bank ROSC and by the Fund's technical assistance note on private sector credit growth. As recommended in these reports, we will adopt an action plan by end-June aimed at implementing the recommendations - particularly on organization, staffing and training - in these reports. To support this process, we will add ten supervision and banking regulation staff by the end of 2006 (new structural benchmark); we stand ready to add more resources as needed. The NBRM also stands ready to use its new powers to impose penalties to help enforce its supervision actions.

\section{At the same time, we will apply a number of measures immediately to improve the quality of bank supervision:}

- We will enforce the existing requirement of accurate and timely electronic data submission through the imposition of financial penalties, once the legal grounds are established.

- $\quad$ Prudential regulations requiring a gradual write-off of foreclosed assets and a mandatory general provision of 1 percent on A-type loans - while keeping the voluntary provision of 2 percent—will be introduced by end-June (new structural benchmark).

- The current guidelines for foreign exchange loans will be tightened by including additional lending requirements for foreign currency loans. These new requirements will apply to both foreign currency and foreign currency-indexed loans.

- We will consult bank auditors more frequently in bank evaluations.

- $\quad$ Further efforts will be made on completing work on bank-peer group comparisons, an early warning system, stress testing, as well as a centralized analysis of large debtors.

22. We are taking steps to enhance bank intermediation, and to strengthen credit culture and market discipline. The NBRM and the government will by end-2006: (i) issue accounting guidelines, a chart of accounts and formats for banks' financial statements in line with IFRS by end-2006 (new structural benchmark); (ii) require banks to publish their annual audited balance sheet on the NBRM webpage; and (iii) require audit reports to include comments on the adequacy and quality of lending policies, risk management, the internal control environment, and quality of internal control. The new Banking Law will allow the NBRM to set additional accounting guidelines and request further information and disclosures from financial institutions that are needed for prudential purposes. By June 2007 we will upgrade the credit registry by reducing the loan threshold, switching to monthly reporting, shortening the data processing period, making financial and other data accessible to banks, and linking it to the central registry (new structural benchmark). 
23. In line with EU recommendations, we will strengthen insurance sector supervision by making it independent. The insurance sector is expanding. To allow the sector to develop further, we will review the legal framework for conducting insurance business and strengthen its supervisory framework based on the findings of a recent technical assistance mission by the World Bank.

\section{Privatization and regulatory reform}

24. The ambitious privatization and regulatory reform programs are on track, albeit with some minor delays:

- $\quad$ Privatization of the state-owned electricity distribution company is moving forward. The government has separated the company's generation, distribution and transmission assets, and launched an international tender for the distribution arm (ESM) alone. The successful bidder was selected and ownership transferred in March 2006. The generation component is planned to be sold in 2007, while the transmission grid, MEPSO, has already been spun-off into a separate company that will remain state owned. While the newly established companies did not request any tariff increase, we will continue to ensure the independence of the energy regulatory commission when it considers future requests for electricity price increases.

- Given sale restrictions under the original privatization covenants, the government's residual shares in the telecommunication sector will now be sold in installments. The first package (of at least 10 percent of Makedonski Telekomunikacii AD) will be sold by end-June (structural performance criterion). The remainder - except for a small minority share of no more than 7 percent — will be sold by end-2006 (structural performance criterion).

- The Ministry of Finance has started the process of selling the government's residual shares in commercial banks (structural benchmark for endDecember 2005). Due to concerns over the effect these sales could have on stock prices, however, we are selling shares in 3 separate packages. The first package of bank stocks was tendered and sold in December 2005. The second package was sold on the stock exchange in mid-February and the third is scheduled to be sold by midApril.

- We are aiming to improve the quality of new and existing regulations affecting business activity. To this end, the government has established with the assistance of the World Bank, and will soon staff, a unit for regulatory impact assessments within the General Secretariat. We will also introduce a legal framework for regulatory impact assessments, a necessary step in developing and implementing a comprehensive approach to regulatory reform. 


\section{We are committed to liberalizing markets for communications and}

transportation. This should reduce costs for businesses and consumers, integrate Macedonia more fully into the world economy, and promote convergence of living standards:

\section{- In February 2005 we passed a liberalized Law on Electronic} Telecommunications that introduced full competition into the telecommunications market. With the supplementary regulations and bylaws completed, we will now fully enforce the new Law and fulfill the requirements of our Stabilization and Association Agreement with the EU. Consistent with this, we will allow interconnection without discrimination and unbundle the local loop. We will show a quantitative improvement in liberalization (to be measured, inter alia, by the number of new VOIP and other service providers, new fixed line competition (expected by end-September), and additional mobile telephone licenses) by end-June (new structural benchmark) and end-December (new structural benchmark). The result should be a lower price structure, that is more closely in line with the rest of Europe.

- We will also liberalize the market for air transport, consistent with our commitment to meeting the EU acquis.

\section{Labour market reform}

26. We will continue to liberalize the labor market. The new Law on Labour Relations in 2005 has started to show an effect. Temporary employment has increased in 2005 and there are also indications of enhanced labor market mobility. We reconsidered our intention to change the Law on the Chamber of Commerce (structural benchmark) as the current law allows sufficient flexibility for employers to join new employers' associations. Next steps in the implementation of the new Law on Labour Relations include the negotiation of a new public sector collective agreement by end-May 2006 and the timely licensing of new trade unions and employers associations. For the public collective wage agreement, we intend to abolish the complexity factors which determined wage scaling in the past. The new law on mediation will also facilitate the resolution of conflicts between employers and employees.

\section{Judicial reform}

27. With the passage of key constitutional amendments in 2005 , we are ready to move to the next phase of judicial reform.

- By end-March we will decide on the use of specialized courts and departments, the number of courts and court structure. We are doing this with the assistance of USAID after a complete statistical analysis of current court caseloads.

- $\quad$ By mid-2006 we will adopt a new Law on Courts and the new Law on the Judicial Council to apply a new system of judicial appointments that strengthen the independence of the judiciary in line with the adopted constitutional amendments. 
- $\quad$ By end-July 2006 we will adopt a new Law on Misdemeanors which will allow administrative bodies to impose penalties on misdemeanor cases without prior court involvement (structural benchmark)

- We enacted a Law on the Academy of Judges in January 2006. We have already equipped and modified a new judicial training center, and will open an academy for judges and prosecutors by October 1, 2006.

- We will make the Law on Enforcement operational by June 1, 2006 which will reduce the work load for courts.

28. We will staff the Judicial Budget Council (JBC) and an analysis of the fiscal cost of judicial reform will be undertaken. An additional eight budget officers will be employed by the court budget office by end-April. With the assistance of USAID's DPK court modernization project, we have been able to finance four additional management, finance, and IT positions within the JBC. The delay in staffing the JBC caused us to miss the end-December structural benchmark on submitting a cost estimate on court reform with the 2006 budget submission. With this problem now solved, the JBC will now provide a detailed fiscal analysis by end-September 2006 (new structural benchmark) which will be used to determine our court budget request for the 2007 budget.

\section{Enhancing the business environment}

29. A number of other structural reforms related to improving the business and investment environment are in progress. These include:

- The structural benchmark on parliamentary approval of the new Bankruptcy Law was not met due to inter-governmental discussions and consultations with World Bank experts. The Parliament passed the Law in March. It incorporates comments by World Bank staff.

- The Law on Audit has been approved by Parliament and the institute for the qualification and certification of auditors will be established by end-March. We are also working with support from the World Bank's BERIS project on removing remaining obstacles to private sector development.

- The number and complexity of licensing requirements for different activities will be reduced. By end-September 2006, the government will publish a list of all licenses administered by line ministries and government agencies, together with their justification (new structural benchmark); those that are not needed will be abolished by end-March 2007 (new structural benchmark). The government will also establish procedures that will scrutinize line ministries' proposals for new licenses in the future. 
- Our plan to enhance transparency of the government's involvement in private sector activities through an annual report has been postponed until end-2006 (reset structural benchmark). As the management of the government's assets (including equity shares and real estate) is spread over several agencies (Ministry of Finance, Ministry of Economy, Pension Fund, Agency for the management of Public Property), the preparation of a report on the government's economic activities was delayed. However, we are committed to finalize the first annual report by end-2006 which will include a list of the state's equity holdings, a justification for the state's involvement and plans for privatization.

\section{Statistics}

30. We are making improvements in the compilation of national statistics. By endMarch, the State Statistical Office (SSO) will publish on its website annual national accounts using a new methodology developed with support of IMF TA. By end-June, we will publish quarterly GDP data in the new methodology and also start reporting quarterly expenditure GDP data (real and nominal). We intend to strengthen labor market data. Also, by endDecember, we will complete a study on improving the methodology for compiling private transfers, for which we are requesting technical assistance.

Sincerely,

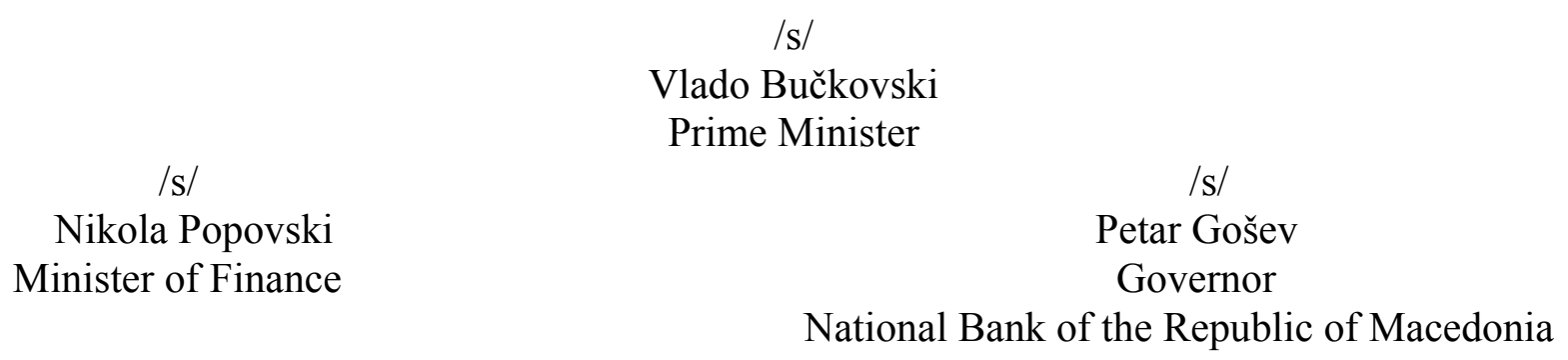

Attachments 
Table 1. FYR Macedonia: Monetary Quantitative Performance Criteria and Indicative Targets for 2005 and 2006 Program Targets and Actual Outcomes for December 2005

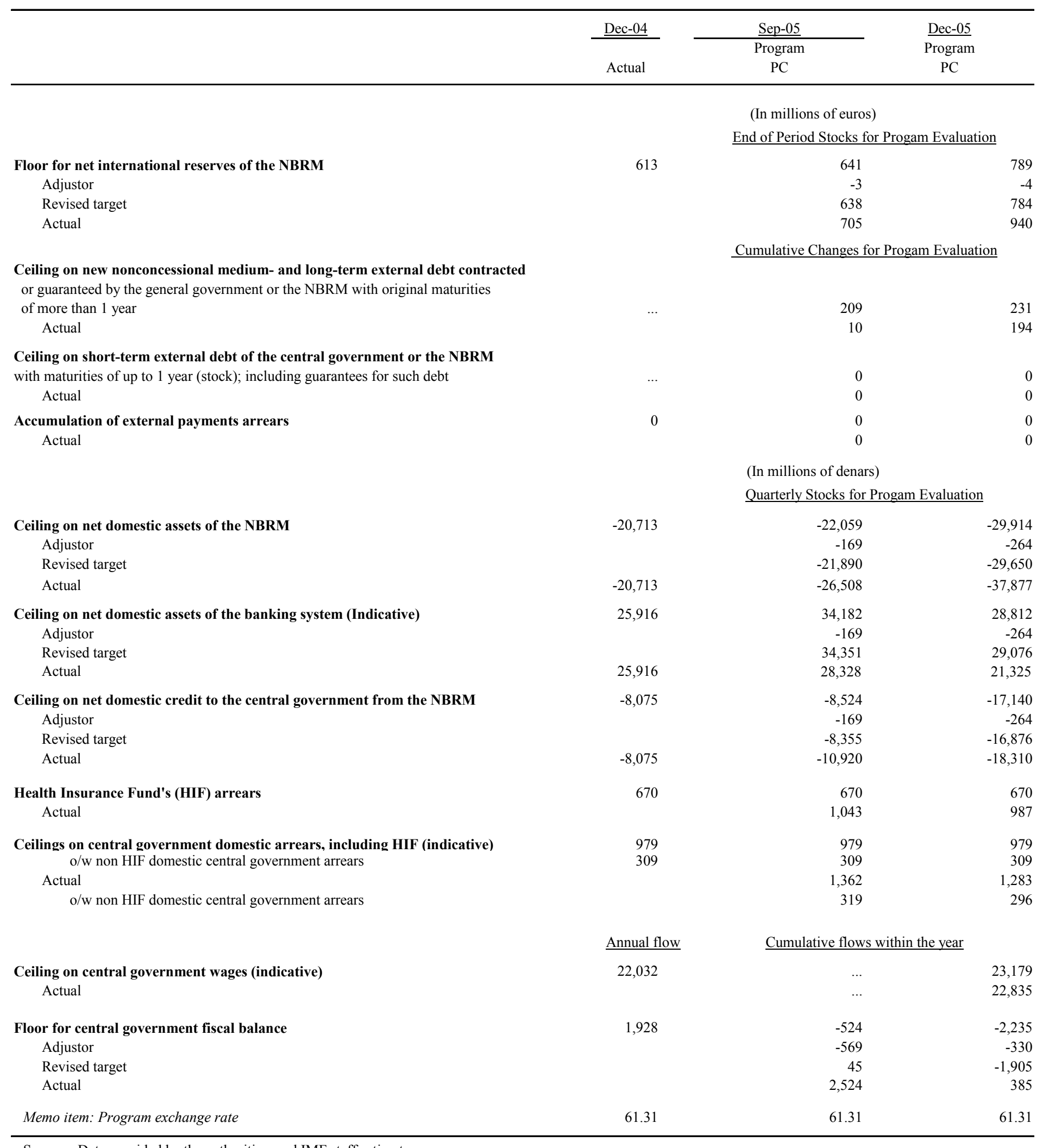

Sources: Data provided by the authorities; and IMF staff estimates. 
Table 1 (continued). FYR Macedonia: Monetary Quantitative Performance Criteria and Indicative Targets for 2005 and 2006 Program Targets and Actual Outcomes for December 2005

Original program
Dec-05 $\quad \underline{\text { Mar-06 }} \quad \underline{\text { Jun-06 }} \quad \underline{\text { Sep-06 }} \quad \underline{\text { Dec-06 }} \quad \underline{\text { Dec-05 }} \quad \underline{\text { Mar-06 }} \quad \underline{\text { Jun-06 }} \quad \underline{\text { Sep-06 }} \quad \underline{\text { Dec-06 }}$

(In millions of euros)

End of Period Stocks for Progam Evaluation
Floor for net international reserves of the NBRM

Adjustor

Actual

Ceiling on new nonconcessional medium- and long-term external debt $1 /$

Actual

Ceiling on short-term external debt 2/ Actual

Accumulation of external payments arrears Actual

Ceiling on net domestic assets of the NBRM Adjustor

Revised target

Actual

Ceiling on net domestic assets of the banking system (indicative)

Adjustor

Revised target

Actual

Ceiling on net domestic credit to the central government

Adjustor

Revised target

Actual

Health Insurance Fund's (HIF) arrears 3/

Actual

Ceilings on central government domestic arrears, including HIF (indicative)

o/w non HIF domestic central government arrears

Actual

$\mathrm{o} / \mathrm{w}$ non HIF domestic central government arrears

Actual

$$
\text { Outcome ( }+ \text { ve is below ceiling) }
$$

Floor for central government fiscal balance

Adjustor

Revised target

Actual

Memo item: Program exchange rate
Revised target from the NBRM

789

$-4$

784

940

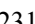

194

0

0

0
$952-958$

$\begin{array}{rrrr}18 & 952 & 958 & 789 \\ \ldots & \ldots & \ldots & -4 \\ \ldots & \ldots & \ldots & 784 \\ & & \ldots & 940\end{array}$

Cumulative Changes for Progam Evaluation

$\begin{array}{rrrrrrrrr}231 & 239 & 246 & 286 & 231 & 231 & 239 & 246 & 286 \\ \ldots & \ldots & \ldots & \ldots & 194 & \ldots & \ldots & \ldots & \ldots \\ 0 & 0 & 0 & 0 & 0 & 0 & 0 & 0 & 0 \\ \ldots & \ldots & \ldots & \ldots & 0 & \ldots & \ldots & \ldots & \ldots \\ 0 & 0 & 0 & 0 & 0 & 0 & 0 & 0 & 0 \\ \ldots & \ldots & \ldots & \ldots & 0 & \ldots & \ldots & \ldots & \ldots\end{array}$

(In millions of denars)

Quarterly Stocks for Progam Evaluation

\begin{tabular}{|c|c|c|c|c|c|c|c|c|c|}
\hline$-29,914$ & $-37,980$ & $-37,764$ & $-39,705$ & $-38,693$ & $-37,877$ & $-37,980$ & $-40,830$ & $-44,303$ & $-44,824$ \\
\hline-264 & $\ldots$ & $\ldots$ & $\ldots$ & $\ldots$ & $\ldots$ & $\ldots$ & $\ldots$ & $\ldots$ & \\
\hline$-29,650$ & $\ldots$ & $\ldots$ & $\ldots$ & $\ldots$ & $\ldots$ & $\ldots$ & $\ldots$ & $\ldots$ & \\
\hline$-37,877$ & $\ldots$ & $\cdots$ & $\cdots$ & $\ldots$ & $\ldots$ & $\ldots$ & $\cdots$ & $\cdots$ & \\
\hline 28,812 & 24,022 & 28,463 & 29,796 & 35,252 & 21,325 & 24,022 & 26,797 & 31,416 & 30,129 \\
\hline-264 & $\ldots$ & $\ldots$ & $\ldots$ & $\ldots$ & $\ldots$ & $\ldots$ & $\ldots$ & $\ldots$ & \\
\hline 29,076 & $\ldots$ & $\ldots$ & $\ldots$ & $\ldots$ & $\ldots$ & $\ldots$ & $\ldots$ & $\ldots$ & \\
\hline 21,325 & $\ldots$ & $\ldots$ & $\ldots$ & $\ldots$ & $\ldots$ & $\ldots$ & $\ldots$ & $\ldots$ & \\
\hline$-17,140$ & $-26,301$ & $-24,123$ & $-23,189$ & $-23,832$ & $-18,310$ & $-26,301$ & $-20,808$ & $-19,996$ & $-25,942$ \\
\hline-264 & $\ldots$ & $\ldots$ & $\ldots$ & $\ldots$ & $\ldots$ & $\ldots$ & $\ldots$ & $\ldots$ & \\
\hline$-16,876$ & $\ldots$ & $\ldots$ & $\ldots$ & $\ldots$ & $\ldots$ & $\ldots$ & $\ldots$ & $\ldots$ & \\
\hline$-18,310$ & $\ldots$ & $\ldots$ & $\ldots$ & $\ldots$ & $\ldots$ & $\ldots$ & $\ldots$ & $\cdots$ & \\
\hline 670 & 670 & 670 & 670 & 670 & 670 & 670 & 670 & 670 & 670 \\
\hline 987 & $\ldots$ & $\ldots$ & $\cdots$ & $\ldots$ & 987 & $\ldots$ & $\ldots$ & $\cdots$ & \\
\hline 979 & 979 & 979 & 979 & 979 & 979 & 979 & 979 & 979 & 979 \\
\hline 309 & 309 & 309 & 309 & 309 & 309 & $\ldots$ & $\ldots$ & $\ldots$ & \\
\hline 1,283 & $\ldots$ & $\ldots$ & $\ldots$ & $\ldots$ & 1,283 & $\ldots$ & $\ldots$ & $\ldots$ & \\
\hline 296 & $\ldots$ & $\ldots$ & $\ldots$ & $\ldots$ & 296 & $\ldots$ & $\ldots$ & $\ldots$ & \\
\hline
\end{tabular}

Annual flow

\begin{tabular}{|c|c|c|c|c|c|c|c|c|c|}
\hline 23,179 & $\ldots$ & $\ldots$ & $\ldots$ & 23,900 & 23,179 & $\ldots$ & $\ldots$ & $\ldots$ & 24,666 \\
\hline 22,835 & $\ldots$ & $\ldots$ & $\ldots$ & $\ldots$ & 22,835 & $\ldots$ & $\ldots$ & $\ldots$ & .. \\
\hline 344 & $\ldots$ & $\ldots$ & $\ldots$ & $\ldots$ & 344 & $\ldots$ & $\ldots$ & $\cdots$ & .. \\
\hline$-2,235$ & -253 & $-1,364$ & $-2,570$ & $-1,851$ & $-2,235$ & -253 & -1364 & -2570 & -1851 \\
\hline-330 & $\ldots$ & $\ldots$ & $\ldots$ & $\ldots$ & -330 & $\ldots$ & $\ldots$ & $\ldots$ & .. \\
\hline$-1,905$ & $\ldots$ & $\ldots$ & $\ldots$ & $\ldots$ & $-1,905$ & $\ldots$ & $\ldots$ & $\ldots$ & .. \\
\hline 385 & $\ldots$ & $\ldots$ & $\ldots$ & $\ldots$ & 385 & $\ldots$ & $\ldots$ & $\ldots$ &.. \\
\hline 61.31 & & & & & 61.31 & & & & \\
\hline
\end{tabular}

Sources: Data provided by the authorities; and IMF staff estimates.

1/ Contracted or guaranteed by the general government or NBRM with original maturities of more than 1 year

$2 /$ Contracted or guaranteed by the central government or NBRM with maturities of up to 1 year (stock)

3/ Indicative target effective June 2006; performance criterion prior. 
Table 2. FYR Macedonia: Structural Conditionality, 2005-2007

\section{End-September 2005}

NBRM will start using repo transactions for monetary interventions.

\section{End-2005}

The 7 largest HCIs prepare 2006 budgets, approved by the $\mathrm{MOH}$, that are in line with the HIF transfers, and become binding ceilings.

PRO designs new organizational chart and fills identified positions required to implement payroll tax reform.

Parliament to enact a 2006 budget that is in line with the program. Government to submit new Banking Law to Parliament.

Judicial Budget Council to prepare 2006 court budget, including an analysis of the fiscal implications of judicial reform.

Amend the Law on the Chamber of Commerce to allow existing members of employers' associations to terminate their membership prior to the negotiation of the next collective agreements.

Remove company registration from courts and establish an integrated company numbering system at the Central Registry.

Parliament approves amendments to the Bankruptcy Law.

MOF will start tendering for the sale of residual state shares in commercial banks.

Government and NBRM to agree on a plan for the use of treasury bills for monetary policy purposes.

NBRM to prepare a Supervisory Development Plan (SDP) for risk based supervision.

HIF to prepare a 2006 budget and to start monthly reporting on budget execution, including transfers to the PHIs in functional classification, on a cash and commitment basis.

The government to finalize the functional analysis of line ministries and prepare a plan for its implementation.
BM Met.

PC Met.

PC Missed; implemented with delay. The organizational chart was finalized on time, but vacant positions were only filled in March.

PC Met.

PC Missed. Authorities decided to prepare more comprehensive version, in cooperation with the Fund; agreed draft should be ready by end-September, submitted to Parliament by end-2006.

BM Missed. A court budget was prepared, but without an analysis of the fiscal implications of judicial reform.

BM Not done. The existing law allows employers sufficient flexibility to terminate membership in employers' associations.

BM Met.

BM Implemented with delay. Draft law was approved by parliament in March 2006.

BM Met.

BM Met.

BM Implemented with delay. SDP was finalized January 2006.

BM Met.

BM Met.

1/ $\mathrm{PC}=$ structural performance criterion; $\mathrm{BM}=$ structural benchmark 
Table 2. FYR Macedonia: Structural Conditionality, 2005-2007 (continued)

\section{June 2006}

Sale of the first tranche (at least 10 percent of the company) of

LTO to pilot test a new computer system which is compatible with systems being developed by the social funds.

Start publishing comprehensive data on the realization of the government's on-lending agreements and government projections for future on-lending.

Anti-corruption commission to audit the financial disclosure reports of randomly chosen senior elected and appointed officials and civil servants.

HIF to report on its spending by economic classification, on a cash and commitment basis, including a breakdown of HCI spending, based on the Q1 2006 outcome.

Pass amendments to the NBRM law and other legislation that revise provisions on the retention/distribution of NBRM profits and to strengthen governor's decision-making powers (new commitment).

Place a budget control officer in the 15 largest HCIs. social contributions.

Liberalize the telecommunication sector (to be measured, inter alia, by the number of new VOIP and other service providers, new fixed line competition, and additional mobile telephone licenses).

Introduce prudential regulations on a gradual write-off of foreclosed assets and a mandatory 1 percent general provision on A-type loans.

\section{July 2006}

Establish a Large Taxpayer Office at PRO and a Large Contributor Office at PDF.

Amend Law on Misdemeanors to allow administrative bodies (such as NBRM, PRO, Customs) to impose sanctions on misdemeanor cases without prior court involvement.

\section{September 2006}

Submit to Parliament legislation on a harmonized base for social contributions.

1/ $\mathrm{PC}=$ structural performance criterion; $\mathrm{BM}=$ structural benchmark 
Table 2. FYR Macedonia: Structural Conditionality, 2005-2007 (continued)

\section{Measure}

Type 1/ Status

\section{September 2006}

Complete draft Banking Law agreed with the staff (focused on, inter alia, bank governance, consolidated supervision, the framework for corrective actions and resolution of weak or insolvent banks, connected lending, and harmonization with EU legislation).

Judicial Budget Council to prepare a detailed analysis of the fiscal implications of judicial reform.

Publish a list of all licenses administered by line ministries and government agencies, together with their justification.

\section{December 2006}

Sale of all of the government's residual shares in Makedonski Telekomunikacii AD (except for a minority shareholding of up to 7 percent).

Issue accounting guidelines, chart of accounts and formats for banks' financial statements in line with IFRS.

Liberalize the telecommunication sector (to be measured, inter alia, by the number of new VOIP and other service providers, new fixed line competition, and additional mobile telephone licenses).

Prepare a report on the government's economic activities.

Add 10 staff to the NBRM's Supervision and Regulation Department. Revise the systematization of selected line ministries and reflect the new systematization in the 2007 budget.

\section{March 2007}

Abolish all licenses administered by line ministries and government agencies that are considered unnecessary.

\section{June 2007}

Upgrade the credit registry.

Prepare a strategy for a harmonized social contribution and personal income tax base.

\section{Date yet to be specified}

Implement legislation by the start of 2007 harmonizing the base for social contributions (details to be specified at Second Review).

Submit to Parliament by end-2006 new Banking Law (details to be specified at Second Review)

Harmonize the base for the personal income tax and social contributions, for implementation at the start of 2008.
$\mathrm{BM}$

BM Reset. The original deadline was end2005.

$\mathrm{BM}$

PC 2006 benchmark.

$1 / \mathrm{PC}=$ structural performance criterion; $\mathrm{BM}=$ structural benchmark 


\section{TeChNiCAL Memorandum OF Understanding}

This Technical Memorandum of Understanding (TMU) defines the variables subject to quantitative targets (performance criteria and indicative benchmarks), established in the Letter of Intent (LOI) and describes the methods to be used in assessing the program performance with respect to these targets.

\section{A. Government and Public Sector}

1. For the purpose of this TMU, the term "central government" covers: central government as defined in the Annual Budget Document, (including Special Revenue Accounts), Employment Fund, Health Insurance Fund, Pension Insurance Fund, Road Fund, and agencies and institutions that are currently treated by the Ministry of Finance as part of government and which correspond to the classification followed by the National Bank of the Republic of Macedonia (NBRM) in its monthly submissions to the Fund of balance sheets of the central bank and the consolidated accounts of the commercial banks. The authorities will inform the Fund staff of any new funds, or other special budgetary and extrabudgetary programs that may be created during the program period to carry out operations of a fiscal nature as defined in the IMF's Manual on Government Financial Statistics, and will ensure that these will be incorporated within the definition of central government.

2. The term "general government" covers the central government as defined in $₫ 1$ and the municipalities which are classified as part of general government according to the budget documents and which are included by the National Bank of the Republic of Macedonia (NBRM) in its monthly submissions to the Fund of balance sheets of the central bank and the consolidated accounts of the commercial banks.

\section{B. Net International Reserves of the NBRM}

3. Net international reserves (NIR) of the NBRM are defined as the difference between NBRM's reserve assets and its reserve liabilities.

4. Reserve assets are defined as liquid and usable foreign convertible currency claims on nonresidents plus monetary gold. Reserve assets of the NBRM thus include monetary gold, SDRs, foreign currency cash, securities, deposits abroad, and the reserve position at the Fund. Excluded from reserve assets are any assets that are frozen, pledged, used as collateral, or otherwise encumbered, claims in foreign exchange arising from transactions in derivative assets (futures, forwards, swaps, and options), and precious metals other than gold.

5. Reserve liabilities are defined as all foreign exchange liabilities of the NBRM to nonresidents and residents, including all credit outstanding from the Fund, arrears on principal or interest payments to commercial banks, suppliers, or official export credit agencies, and future and contingent commitments to sell foreign exchange arising from 
transactions in derivative assets (futures, forwards, swaps, and options). Central government's foreign exchange deposits at the NBRM are excluded from reserve liabilities.

6. For program purposes, all foreign currency-related assets and liabilities are valued at program exchange rates as defined in Section J.

7. The schedule of end-quarter floors on net international reserves (NIR floors) has been established in Table 1 of the LOI. The changes in the NIR will be measured in euros excluding valuation effects calculated according to the methodology described in Section J.

\section{Adjustors}

8. The NIR floors are set based on the assumption that balance of payments financing will amount to the baseline shown in Table 1.

Balance of payments financing is defined as the sum of: (i) gross disbursement of foreign loans or grants to the central government or the NBRM for balance of payments financing, including issuance of Eurobonds, minus the planned prepayment of foreign loans; (ii) privatization proceeds and lump sum proceeds from concession fees in foreign currency; and, (iii) proceeds from the restitution of foreign assets of the former SFRY. Project loans and grants, and purchases from the IMF are not considered balance of payments financing for this purpose.

9. If balance of payments financing deviates from the baseline path shown in Table 1, the NIR floors of the NBRM will be adjusted as follows:

- $\quad$ The NIR floor will be adjusted upward (downward) to the same extent as any upward (downward) deviation in grants and loan disbursements from bilateral and multilateral donors, with the provision that the downward adjustment to the floor will not exceed the equivalent of EUR 30 million on a cumulative basis.

- $\quad$ The NIR floors will be adjusted upward (downward) by the amount of any prepayment of external debt falling short of (exceeding) the baseline.

- $\quad$ The NIR floors will be adjusted upward for any lump sum proceeds from concession fees in foreign currency exceeding the baseline defined in Table 1.

- The NIR floors will be adjusted upward for the restitution of foreign assets of the former SFRY as a result of succession proceeds exceeding the baseline defined in Table 1.

10. The NIR floors of the NBRM for end-June 2006, end-September 2006, and endDecember 2006 (Table 1 of the LOI) will be adjusted upward (downward) for any excess (shortfall) in privatization receipts over EUR 245 million. In no case the downward adjustment for the shortfall in privatization receipts will exceed EUR 100 million. 


\section{Net Domestic Assets of the NBRM}

11. Net domestic assets (NDA) of the NBRM are defined as reserve money minus the net foreign assets (NFA) of the NBRM.

12. Reserve money is defined as currency in circulation (outside banks), vault cash of banks, and required and excess reserve deposits of banks in denars and in foreign currency held at the NBRM or at the NBRM accounts abroad.

13. Net foreign assets (NFA) of the NBRM are defined as reserve assets plus those foreign assets of the NBRM that are excluded from reserve assets under the definition in $q 4$ of this TMU, minus foreign exchange liabilities of the NBRM to nonresidents (as defined in \5).

14. The schedule of end-quarter ceilings on the net domestic assets (ceilings for NDA) has been established in Table 1 of the LOI.

\section{Adjustors}

15. If balance of payments financing deviates from the baseline path, the ceiling for the NDA of the NBRM will be adjusted as follows:

- The NDA ceilings will be adjusted downward (upward) to the same extent as any upward (downward) deviation in grants and loan disbursements from bilateral and multilateral donors, with the provision that the upward adjustment to the floor will not exceed the equivalent of EUR 30 million.

- $\quad$ The NDA ceiling will be adjusted downward (upward) by the amount of any prepayment of external debt falling short of (exceeding) the baseline defined in Table 1.

- $\quad$ The ceilings for the NDA of the NBRM will be adjusted downward for lump sum proceeds from concession fees in foreign currency exceeding the baseline defined in Table 1.

- $\quad$ The ceilings for the NDA of the NBRM will be adjusted downward for the restitution of foreign assets of the former SFRY as a result of succession proceeds exceeding the baseline defined in Table 1.

16. The ceilings for the NDA of the NBRM for end-June 2006, end-September 2006, and end-December 2006 (Table 1 of the LOI) will be adjusted downward (upward) for any excess (shortfall) in privatization receipts over EUR 245 million. In no case the upward adjustment for the shortfall in privatization receipts will exceed EUR 100 million. 


\section{Net Domestic Assets of the Banking System}

17. Net domestic assets (NDA) of the banking system, which includes the NBRM and the deposit money banks, are defined as broad money (M3) minus the net foreign assets (NFA) of the banking system.

18. Broad money (M3) includes currency in circulation, demand deposits, quasideposits, and non-monetary deposits (time deposits over 12 months and restricted deposits) of the non-central government denominated in denars and in foreign currency.

19. NFA of the banking system are defined as the banking system's foreign assets minus foreign liabilities.

20. The schedule of end-quarter indicative ceilings on the net domestic assets of the banking system has been established in Table 1of the LOI.

\section{Adjustors}

21. The ceilings on the NDA of the banking system will be subject to the same adjustors as the ceilings on the NDA of the NBRM.

\section{E. Net Credit to the Central Government from the NBRM}

22. Net credit to the central government from the NBRM is defined as credit in denars and foreign currency to the central government from the NBRM minus total central government deposits in denars and foreign currency with the NBRM. For the purpose of this program, accounts of the central government include all accounts recorded as central government accounts in the monetary statistics reported by the NBRM in accordance with the definition of central government $\$ 1$. Excluded from this definition are any T-bills issued for monetary policy purposes and corresponding government deposits at the NBRM, and the unclaimed portion of the payment of principal and interest on frozen foreign currency deposits.

23. The ceiling for end-March 2006 has been established for the cumulative change in the net credit from the NBRM to the central government from the actual level as of endDecember 2004. Quarterly ceilings for June, September and December have been established for the cumulative changes in net credit from the NBRM to the central government from the actual level at end-December 2005 (Table 1 of the LOI).

\section{Adjustors}

24. The ceilings on net credit to the central government from the NBRM will be subject to the same adjustors as the ceilings for the NDA of the NBRM. 


\section{F. Government Fiscal Balances}

25. Quarterly floors for the cumulative changes in central government fiscal balances will be determined and monitored from the financing side beginning end-December 2005 (Table 1 of the LOI). The financing flows will be measured as a sum of domestic financing, foreign financing, and privatization proceeds.

26. Domestic financing for the central government includes net credit from the domestic banking system (excluding any T-bills issued for monetary policy purposes and corresponding government deposits at the NBRM, and the unclaimed portion of the repayment of frozen foreign currency deposits), net placement of securities outside the domestic banking system and other net credit from the domestic non-banking sector, and net variation in domestic arrears, as defined in $₫ 36$ below. Foreign financing for the central government (converted using the valuation methodology described in Section J) includes disbursements of external loans received by the central government, including disbursements received for foreign financed projects of budget users and extrabudgetary funds, and restitution of foreign assets of the former SFRY as a result of succession proceedings minus amortization due or pre-paid, and rescheduled debt service payments programmed to be paid out. Privatization proceeds for the central government include privatization proceeds and lump sum proceeds from concession fees in denars and foreign currency.

27. The general government fiscal balance includes, in addition to the central government fiscal balance, the financing position of the municipalities included in the definition of general government in $\Psi 2$. It is expected that, quantitative targets for the general government fiscal balance will be set on the occasion of the $3^{\text {rd }}$ semi-annual program review, provided that sufficiently comprehensive and reliable data on municipalities' finances will have become available.

\section{Adjustors}

28. The floor on central government fiscal balance for end-March 2006 will be adjusted upward by any shortfalls of gross external financing for central government's foreign financed projects spending (including the Road Fund) with respect to the cumulative baseline of EUR 43.0 million from end-2004.

29. The floor on the central government fiscal balance for end-June, end-September and end-December 2006 will be adjusted upward by any shortfalls of gross external financing for central government's foreign financed projects spending (including the Road Fund) with respect to the following cumulative baseline from end-2005:

End-June 2006

End-September 2006

End-December 2006
EUR 19.3 million;

EUR 32.4 million;

EUR 35.3 million. 


\section{G. Central Government Wage Bill}

30. The ceiling on the central government wage bill includes central government wages and salaries, including allowances.

31. Annual ceilings have been established for the central government wage bill (Table 1 of the LOI).

\section{H. Debt}

32. For assessing fiscal sustainability for program purposes, the standard analysis of the consolidated central government's debt sustainability will be complemented with an analysis that will include debt contracted and guaranteed by central and general governments and available information on government's contingent liabilities, such as external debt contracted by public and state owned enterprises without explicit government guarantees.

33. The limit on medium and long-term debt (Table 1 of the LOI) applies to the contracting or guaranteeing by any branch of the government or the NBRM of new nonconcessional external debt with an original maturity of more than one year. This performance criterion applies not only to debt as defined in point No. 9 of the Guidelines on Performance Criteria with Respect to Foreign Debt adopted on August 24, 2000 by the Executive Board of the IMF ${ }^{1}$, but also to commitments contracted or guaranteed for which value has not been received. Excluded from this performance criterion are changes in indebtedness resulting from refinancing credits and rescheduling operations (including the deferral of interest on commercial debt), credits extended by the IMF and the BIS, and credits on concessional terms, defined as those with a grant element of 35 percent or more calculated using the OECD Commercial Interest Reference Rates (CIRRs) applicable for the program period. Specifically, the discount rates for debts with maturities less than 15 years will be based on the average CIRR of the previous 6 months, and for debts with maturities of 15 years and more the average CIRR of the previous 10 years. Debt falling within the limit shall be valued in euro at the exchange rate prevailing at the time the contract or guarantee becomes effective.

34. The limit on short-term debt (Table 1 of the LOI) applies to the outstanding stock of short-term government and government-guaranteed external debt and the NBRM with an original maturity of up to and including one year. The term "debt" has the meaning set forth in point No. 9 of the Guidelines on Performance Criteria with Respect to Foreign Debt

\footnotetext{
${ }^{1}$ Decision No. 6230-(79/140) August 3, 1979, as amended by Decision Nos. 11096-(95/100), October 25, 1995, and 12274-(00/85), August 24, 2000. Under the Guidelines on Performance Criteria with Respect to Foreign Debt adopted on August 24, 2000 by the Executive Board of the IMF the definition of "debt" has been broadened with respect to the conventional definition to include, among other things, such instruments as financial leases.
} 
adopted on August 24, 2000 by the Executive Board of the IMF. Excluded from this performance criterion are changes in indebtedness resulting from rescheduling operations (including the deferral of interest on commercial debt), and normal import-related credits. Debt falling within the limit shall be valued in euro at the program exchange rates. There was no official short-term debt or guarantees on outstanding short-term debt as of endDecember 2004.

\section{External and Domestic Payments Arrears}

35. External payments arrears consist of the total past-due amounts of debt service obligations (interest and principal) on government, government-guaranteed, and the NBRM external debt, excluding arrears on external debt service obligations pending the conclusion of debt rescheduling agreements. ${ }^{2}$ Under the program, the nonaccumulation of external payments arrears is a continuous performance criterion. As of end-December 2004 there were no outstanding external payment arrears as defined above.

36. Central government domestic arrears, excluding those to suppliers, are defined to include all payment delays to: (i) banks for bond payments (including for the repayment of frozen foreign currency deposits); (ii) individuals for Social Assistance Program payments; (iii) central government employees including for wages and salaries, and food and travel allowances; (iv) benefit recipients of the Child Care Program; (v) local governments. The definition excludes the customary lag in paying wages, social assistance and child allowance payments, and transfers to the extra-budgetary funds (in the following month after they accrue). According to the definition here, and as reported to IMF staff, as of end-December 2004 there were no central government domestic arrears, excluding those to suppliers. Under the program, the outstanding stock of domestic arrears, as defined above, will not exceed at any time the amount outstanding as of end-December 2004.

37. Central government domestic arrears to suppliers are defined as obligations to suppliers of the core budget users and the Health Fund, which are due but not paid by more than 60 days and are non-disputed. As defined here, and as reported to Fund staff, the stock of arrears to suppliers stood at 979 million denars as of end-December 2004. Under the program, the outstanding stock of domestic arrears, as defined above, will not exceed the amount outstanding as of end-December 2004.

38. A separate sub-ceiling is set for the Health Fund arrears, as defined above in $₫ 37$ and as reported to Fund staff. Under the program the aggregate outstanding stock of arrears will not exceed the amount outstanding as of end-2004. (The aggregate stock of these arrears stood at 670 million denars as of end-December 2004).

\footnotetext{
${ }^{2}$ Amounts are only considered past-due after the contractual grace period expired.
} 


\section{J. Valuation}

\section{Valuation of the NBRM balance sheet and the monetary survey}

39. For the programmed foreign exchange projections, the program exchange rates were applied.

40. For program purposes, all foreign currency-related assets and liabilities will be evaluated at program exchange rates. For 2006, the program exchange rates are those that prevailed on December 31, 2004. In particular, EUR1 $=61.3100$ denars, US $\$ 1=45.0676$ denars; SDR1= 69.9903 denars, and EUR1=1.3604 U.S. dollars.

41. Performance will be measured in constant exchange rates. For this methodology, assets and liabilities of the banking system will be valued as follows: The stocks of assets and liabilities denominated in foreign currencies outstanding at December 31, 2005 are valued at the program exchange rates defined above. Gold is valued at the price fixed in the London market at end-December 2004 (US\$ 438.00 per ounce). Changes in assets and liabilities will also be valued at these exchange rates. The exchange rate effects on the foreign currency denominated assets and liabilities of commercial banks will be estimated on the basis of their currency composition, as provided by the NBRM banking supervision department.

\section{Valuation of NIR}

42. For the programmed foreign exchange projections, the program exchange rates were applied.

43. For program monitoring, the NBRM estimates the valuation effects on the NIR of the NBRM as follows. On a daily basis all foreign currency denominated balances are converted into Euros using the middle rates from the NBRM official exchange rate list for the same day. These balances are compared to the balances in Euros at the end of the previous day calculated in the same way (i.e., using the middle rates from the NBRM official exchange rate list for that day). The change in the daily Euro denominated balances, so calculated, is compared to the recorded daily transaction flows converted in Euros using the same methodology. Any difference between the two values is attributed to valuation effects.

\section{Valuation of the fiscal deficit}

44. For the programmed foreign exchange projections, the program exchange rates were applied.

45. For fiscal deficit measuring purposes, the foreign currency component of deficit financing will also be converted into denars at constant program exchange rates. 


\section{K. Monitoring and Reporting Requirements}

46. Performance under the program will be monitored from information provided to the IMF by the NBRM and the Ministry of Finance. All data will be monthly, unless otherwise specified, and should be submitted by the authorities to the IMF staff within 30 days of the end of each month, for the minimum of three consecutive months prior to the IMF Board discussion on the arrangement, unless otherwise specified. In addition, data on performance at the program test dates will be submitted with a cover letter signed by an authorized official.

47. The following information will be supplied to the IMF by the Ministry of Finance: (i) fiscal table for the consolidated central government (i.e., including special revenue accounts and the extra-budgetary funds) (40 days after the end of each month); (ii) monthly information on privatization receipts (including detailed description of cash payments in local and foreign currency and payments with government bonds); (ii) data on workers registered as unemployed with the unemployment fund; (iv) information on guarantees given on new debt, on new debt contracted by the government, government agencies, and public enterprises and on debt stock in gross and net terms; (v) information on domestic arrears, including to suppliers and distinguishing between court disputed and non-disputed arrears; (vi) data on outlays on structural reforms and public administration reforms; (vii) data on the claimed and unclaimed portion of the repayment of frozen foreign currency deposits; and (ix) information on the local government fiscal accounts (starting April 2006). In addition, the MOF, in coordination with the NBRM, will provide quarterly reports on the reconciliation of monetary and fiscal data on net government position vis-à-vis the banking system, and data on the holders of government securities broken down between banks and non-bank entities.

49. The NBRM will supply: (i) balance sheets of the NBRM and the consolidated accounts of the commercial banks - both should include details of the credit and deposits position of funds and other government entities as listed in $₫ 1$ (20 days after the end of the month); (ii) the monetary survey; (iii) data on components of NIR of the NBRM as defined in section B, valued in euros adjusted for valuation changes; (iv) statement from the Road Fund indicating its balances (in denars and foreign currency) at the NBRM and at the commercial banks separately; (v) the foreign exchange cash flow of the NBRM, including the level of official reserves, if necessary, reconciled with the NBRM balance sheet data for NFA; (vi) daily and monthly closing and average exchange rates; (vii) detailed data on exports and imports; (viii) information on all overdue payments on short-term external debt and on medium- and long-term external debt; (ix) data on foreign borrowing including gross disbursements, amortization, and interest payments by debtors (central government, agencies and public enterprises); (x) information on lending by domestic money banks according to credit ratings of borrowers; (xi) data on offbalance sheet activity of domestic money banks; (xii) data on each domestic money banks' compliance with prudential regulations will be provided on a quarterly basis; (xiv) detailed reporting on commercial banks assets and liabilities, including breakdowns by currency and maturity, on a quarterly basis; (xv) report on commercial banks total credit exposure by currency, currency indexation and sector, on a quarterly basis; (xvi) monthly information on 
commercial banks lending and deposits indexed to foreign currencies; (xvii) monthly information on deposit and lending interest rates. Monthly data on all components of balance of payments will be submitted within $2 \frac{1}{2}$ months of the end of each month. By the end of the following months, the NBRM will provide preliminary trade data based on customs information. Data on stock of external debt will be provided on a quarterly basis, within 30 days of the end of the quarter. For the reports under points X, XII, XIV and XV, data for the period ending in March and September will be provided within 50 days of the end of the period; data for the period ending in June will be provided within 70 days of the end of period; and the end of the year data will be provided within 100 days of the end of period.

50. The State Statistics Office (SSO) office will supply monthly updates on CPI, PPI, industrial production, wages, employment, and import and export data. The SSO will also prepare quarterly GDP data three months after the end of the quarter. In case of changes in the statistical methodology, the SSO will provide data in the new and old methodology for at least one reporting point. The SSO will also provide updates when historic time series get corrected. All submissions will be in electronic form. 
Table 1. Balance of Payments Financing Assumptions, 2005-2006 1/

(quarterly flows in millions of euros, unless otherwise indicated)

\begin{tabular}{|c|c|c|c|c|}
\hline & \multicolumn{4}{|c|}{ Financing Assumptions for PCs up to end-March 2006} \\
\hline & Jun-05 & Sep-05 & Dec-05 & Mar-06 \\
\hline Grants & 6.3 & 0.0 & 7.0 & 0.0 \\
\hline The Netherlands & 6.3 & 0.0 & 7.0 & 0.0 \\
\hline Other & 0.0 & 0.0 & 0.0 & 0.0 \\
\hline Loans & 19.2 & 6.8 & 185.6 & 11.2 \\
\hline $\mathrm{IBRD} / \mathrm{IDA}$ & 14.7 & 0.0 & 22.1 & 0.0 \\
\hline Euro Bond & 0.0 & 0.0 & 150.0 & 0.0 \\
\hline EBRD (ESM pre-privatization loan) & 4.5 & 6.8 & 13.5 & 11.2 \\
\hline Privatization proceeds in foreign currency & 0.0 & 0.0 & 0.0 & 250.0 \\
\hline Lump-sum proceeds from concession fees & 0.0 & 0.0 & 0.0 & 0.0 \\
\hline Restitution of foreign assets of the former SFRY & 0.0 & 0.0 & 6.5 & 0.0 \\
\hline Prepayment of foreign loans (minus) & 0.0 & 0.0 & 0.0 & -120.1 \\
\hline \multicolumn{5}{|l|}{ Total } \\
\hline Quarterly flows & 25.5 & 6.8 & 199.0 & 141.2 \\
\hline \multirow{3}{*}{ Cumulative from end-December 2004} & 25.5 & 32.3 & 231.3 & 372.5 \\
\hline & \multicolumn{4}{|c|}{ Financing Assumptions for PCs from end-June 2006 to end-December 2006} \\
\hline & Mar-06 & Jun-06 & Sep-06 & Dec-06 \\
\hline Grants & 0.0 & 0.0 & 0.0 & 7.0 \\
\hline The Netherlands & 0.0 & 0.0 & 0.0 & 7.0 \\
\hline \multicolumn{5}{|l|}{ Other } \\
\hline Loans & 13.5 & 11.3 & 0.0 & 22.1 \\
\hline IBRD/IDA & 0.0 & 0.0 & 0.0 & 22.1 \\
\hline Euro Bond & 0.0 & 0.0 & 0.0 & 0.0 \\
\hline EBRD (ESM pre-privatization loan) & 13.5 & 11.3 & 0.0 & 0.0 \\
\hline Privatization proceeds in foreign currency & 0.0 & 165.0 & 0.0 & 85.0 \\
\hline Lump-sum proceeds from concession fees & 0.0 & 0.0 & 0.0 & 0.0 \\
\hline Restitution of foreign assets of the former SFRY & 0.0 & 0.0 & 0.0 & 0.0 \\
\hline Prepayment of foreign loans (minus) & -120.1 & 0.0 & 0.0 & 0.0 \\
\hline \multicolumn{5}{|l|}{ Total } \\
\hline Quarterly flows & -106.6 & 176.3 & 0.0 & 114.1 \\
\hline Cumulative from end-December 2004 & -106.6 & 69.7 & 69.7 & 183.8 \\
\hline
\end{tabular}

Sources: Data provided by the authorities; and IMF staff estimates.

$1 /$ At program exchange rates. 


\section{Statement by the IMF Staff Representative April 19, 2006}

This statement provides information on developments since the issuance of the staff report for the Former Yugoslav Republic of Macedonia's Request for the First Review Under the Stand-By Arrangement, and Request for Waiver of Performance Criteria, and Extension of Repurchase Expectations. It does not change the thrust of the staff appraisal.

The authorities have successfully overcome a last-minute setback to the program. Late last week, opposition MPs introduced an amendment to the Pensions Law that gave immediate pension rights to workers with 25 years of service who had lost their jobs due to bankruptcy of the company. With only the minimum number of MPs present required to reach a quorum, the amendment passed unexpectedly.

If allowed to stand, the amendment would have been inconsistent with the goals of the program. The authorities estimate that dropping the age requirement for pensioners would have an annual cost of almost $1 / 2$ percent of GDP. This would threaten the program's deficit target and the sustainability of the pension system. The higher wage taxes needed to offset this would be at odds with the program's labor market reforms.

The Government has acted quickly to make sure that the amendment does not come into force. On Monday it issued a public statement opposing the amendment and asked the President to stop the law from coming into force. This morning, President Crvenkovski announced that he would not sign the amendment into law, effectively vetoing it. A second vote can override the veto, but this would require an absolute majority of all MPs, not just those MPs present. The Government is committed to using its majority to prevent the amendment from being passed again.

On a final note, preliminary data suggest that the authorities exceeded the end-March performance criterion on net international reserves by approximately $€ 50$ million. 
Press Release No. 06/77

FOR IMMEDIATE RELEASE

International Monetary Fund

April 20, 2006

Washington, D.C. 20431 USA

\section{IMF Executive Board Completes First Review Under Stand-By Arrangement with the Former Yugoslav Republic of Macedonia}

The Executive Board of the International Monetary Fund (IMF) today completed the first review of the former Yugoslav Republic of Macedonia's economic performance under a Stand-By Arrangement.

In completing the review, the Board approved the authorities' requests for waivers of applicability of seven end-March 2006 quantitative performance criteria, as well as waivers for the non-observance of the end-December 2005 quantitative performance criterion on the arrears of the Health Insurance Fund and the end-December 2005 structural performance criteria on the designation of a new organizational chart by the Public Revenue Office and on the submission of a new Banking Law to Parliament. The Board also approved the authorities' request for an extension of the repurchase expectations to the obligations schedule in an amount equivalent to SDR 13.4 million, that arise from September 30, 2006 through December 31, 2007.

The three-year Stand-By Arrangement for an amount equivalent to SDR 51.7 million (about US\$74.5 million) was approved on August 31, 2005 (see Press Release No. 05/196).

The authorities are now treating the arrangement as precautionary.

Following the Executive Board discussion of Macedonia, Mr. Takatoshi Kato, Deputy Managing Director and Acting Chair, made the following statement:

"The economic performance of FYR Macedonia under the Fund-supported program has been encouraging, with stable growth, low inflation, falling unemployment, and a significant improvement in the balance of payments position. Fiscal restraint, a prudent monetary policy, and structural reforms, together with the recently announced European Union (EU) candidacy, should help to increase confidence further and lead to lower interest rates, placing the country on a more rapid growth path.

“The central bank's policy of letting interest rates fall gradually while building up reserves as the current account position strengthens has been successful in maintaining exchange rate 
stability and low inflation. Should the present high level of foreign exchange inflows persist, monetary and fiscal policy should be ready to respond in order to keep inflation in check and support exchange rate stability. The authorities' plans to revise the Banking Law and improve banking supervision are also welcome in this context.

"A sound fiscal policy has underpinned the macroeconomic stabilization. The authorities are committed to adhere to the fiscal deficit target and to resist spending pressures, as evidenced by the authorities' latest decision regarding the pension eligibility requirements. Further public sector reforms should help sustain fiscal adjustment and create room for more public investment. Strengthening of tax administration and the planned harmonization of the bases for social security contributions will also help.

"Structural reforms have already contributed to an improved business environment, but further actions will enhance competitiveness and help prepare for eventual EU accession. The introduction of a one-stop shop system for company registration has reduced business startup costs, and the authorities are committed to streamlining business licensing further. Judicial reform, including court organization and the training of judges, will also help support business development. Privatization of the electricity distribution company has been successful, and should now be accompanied by steps to sell the remaining telecom shares and to liberalize this sector, in line with existing EU commitments. These and related efforts should improve the business climate and boost foreign direct investment," Mr. Kato said. 


\section{Statement by Jeroen Kremers, Executive Director for Former Yugoslav Republic of Macedonia April 17, 2006}

Macedonia's economic performance has remained strong, reflecting the authorities' commitment to build on the progress made and to deepen the economic reform agenda. This commitment is underpinned by last December's European Council decision to grant Macedonia EU-candidate status. Real GDP growth reached 4 percent for the second consecutive year. The robust growth in combination with labor market liberalization, helped to boost employment. Reflecting the policy stance and a considerable increase in transfers, Macedonia's external position has improved substantially and is projected to remain sustainable in the medium term. At the same time, prudent and well-coordinated monetary and fiscal policies kept inflation at a low level. Moreover, financial market confidence and the capital account appear to be improving, as evidenced by the large oversubscription of Macedonia's first Eurobond issue at the end of last year, followed by a rating upgrade from Standard and Poor's. The outlook for 2006 remains favorable with real GDP growth projected to remain at 4 percent, while inflation is expected to rise somewhat as a result of the increase in cigarette taxes and the expected administrative increase of electricity prices.

The authorities attach great value to the close relationship with the Fund, and appreciate staff's comprehensive report and the fruitful program review discussions. They are pleased that the program is on track, with the monetary and fiscal targets being met, some with wide margins. At the same time, two structural and one quantitative performance criteria were missed, as further explained below. Reiterating their strong commitment to the comprehensive reform agenda, which also aims at promoting convergence with EU standards, the authorities request the completion of the first review under the Stand-By Arrangement and a waiver of the missed performance criteria. I would like to emphasize that the authorities intend to treat the SBA as precautionary. To smooth the debt services profile, the authorities request an extension of repurchase expectations totaling SDR 13.39 million, that arise from September 30, 2006 through December 31, 2007.

\section{Fiscal policy}

A budget surplus has been achieved for the second consecutive year. The program target was exceeded by more than 1 percent of GDP, due to restraint in public employment, procurement delays, and underexecution of Special Revenue Account (SRA) spending.

The authorities are committed to a 2006 fiscal deficit target of 0.6 percent of GDP. They agree with staff that this target is appropriate given the improvement in the current account, lower public debt ratios, and the credible fiscal stance. This will be further underpinned by maintaining a tight wage policy and lower transfers, keeping current expenditures roughly constant in real terms.

An important element of the fiscal agenda is the implementation of the broad-based reform of tax administration with technical support from the Netherlands. Considerable progress has been made in this area, including Parliamentary approval of the new Law on 
Tax Administration Procedures, expanding taxpayer protection and broadening the Public Revenue Office's (PRO) authority. The PRO's organizational chart has been redesigned to comply with program requirements. Moreover, the authorities continue to make progress toward improving arrears collection, tax payer registration, performance measurement, and harmonization of personal income tax and social contribution collections. Preparations for establishing a Large Tax Payer Office (LTO) at the PRO and Large Contributor Office (LCO) at the Pension Fund are on track.

The authorities plan to harmonize the base for personal income tax (PIT) and social contributions as reflected in the program. However, given the complexity of this measure, they have decided to proceed with the implementation in two phases. The first phase will focus on harmonizing the base for social contribution, and will be completed by year-end, while the second phase aims at harmonizing the base for personal income tax and will become effective in 2008 .

On the expenditure side, further measures aim at improving the quality and efficiency of fiscal spending and control mechanisms. To this end, a Public Expenditure review began in February with World Bank assistance and its preliminary findings will help guide the 2007 budget. Also, the authorities will start the regular monitoring and reporting exercises and preaccession fiscal surveillance required for EU membership.

The authorities attach great importance to containing arrears in the health sector within program parameters and regret the worsening of the overall health finances despite improvements at the end of 2005. To address this shortfall, further corrective measures have been taken. In particular, starting as of January 1, 2006, public health institutions (HCIs) are operating within hard budget ceilings. In line with World Bank guidance the Health Insurance Fund (HIF) has introduced competitive international tendering for drugs on the positive list, resulting in 0.2 percent of GDP savings. Also, additional measures envisaged in the program will help to improve monitoring of the debt level and budget execution of Public Health Institutions.

The debt sustainability analysis shows that debt dynamics are generally subdued and the authorities have used the favorable environment to substantially upgrade debt management at the Ministry of Finance.

\section{Monetary policy and exchange rate regime}

The National Bank of the Republic of Macedonia (NBRM) continues to support the economic program by maintaining the de facto pegged exchange rate regime backed by an adequate level of international reserves. The exchange rate has served Macedonia well as a nominal anchor. There are also indications that competitiveness pressures have been easing. The NBRM's monetary program for 2006 is consistent with average broad money growth of about 20 percent. Given the expected considerable increase in capital inflows, the authorities project gross official reserves to reach 1.3 billion euro by the end of the year, covering over 4 months of projected imports. 
The authorities expect a slight fall in the level of euroization as the demand for denar assets remains strong. To avoid inflationary pressures and ensure the continued success of the exchange rate regime, they stand ready to sterilize capital inflows by issuing central bank and treasury bills, if needed. At the same time, to ensure a prudent monetary stance and to prevent the increase in reserves from resulting in excessive monetary expansion, the NBRM will lock in two-thirds of the 2005 Net Foreign Assets overperformance. Given the importance of the government securities market for monetary policy implementation, the NBRM has established regulatory and infrastructure framework for secondary trading of treasury bills, by creating the over the counter market (OTC) and introducing repo. This enables settlement in real time and increases the efficiency of liquidity management.

Safeguarding the NBRM's independence and strengthening its financial soundness remain key. In this vein, and in line with Fund recommendations, by end-June the NBRM Law will be amended to allow the retention of 70 percent of its profits in case general reserves are below the statutory limit and to protect its decisions in the areas of banking licensing, receivership and bankruptcy from court reversal. Furthermore, the authorities intend to revise the National Bank Law next year to make it consistent with EU standards.

In order to improve the soundness of the banking system, the authorities are preparing a comprehensive revision of the legal framework. They have produced a new draft of the Banking Law aimed at addressing a number of important areas, including governance issues, clarification of the roles of the Audit and the Risk Management Committees, and increased capital and enhanced licensing requirements. The submission of the new Banking Law to Parliament was postponed to December 2006, as the authorities believe that the law will benefit considerably from additional provisions that bring it more in line with EU standards and international best practices. Further IMF assistance has been requested in this field. In addition, the authorities will review the Law on Deposit Insurance to make it consistent with the new Banking Law.

The NBRM has undertaken a number of steps to strengthen banking supervision. With the help of the World Bank, a Supervisory Development Plan (SDP) has been developed to enable a more risk-based, anticipatory approach to banking supervision, and to facilitate implementation. To that effect, an MFD resident advisor will be in place by May. At the same time, a number of measures aimed at improving the quality of banking supervision have been introduced, including enforcement of existing requirements for accurate and timely electronic data submission, tightening guidelines for foreign exchange loans, and completing the work on bank peer-group comparison.

\section{Structural reforms}

While Macedonia has made substantial progress, the authorities recognize that much remains to be done in the areas of regulatory reform, liberalization of telecommunications and business environment.

One of the centerpieces of the reform program, which will have a major impact on the business environment, continues to be the ambitious and comprehensive judicial reform program. With the passage of the key constitutional amendment in 2005, the authorities are 
moving to the next phase of the reform. By mid-2006 the Parliament will adopt a new Law on Courts and the Law on Judicial Council aimed at strengthening the independence of the Judiciary. The Law on Enforcement will become operational by June 1, 2006, which will reduce the workload for courts. While reaffirming their commitment to staff the Judicial Budget Council (JBC) and to undertake an analysis of the fiscal cost of judicial reform, the authorities believe that sufficient resources are available in the current court budget and from donors to cover the start-up costs in 2006.

Following the successful privatization of the state-owned electricity distribution company, the authorities plan to sell the generation component in 2007. At the same time, the authorities reiterate their commitment to ensure the independence of the energy regulatory commission, e.g. in case of requests from the new operators for electricity price increases. Furthermore, the authorities remain determined to implement the February 2005 Law on Electronic Communications and to meet their program commitment regarding the sale of its remaining telephone company shares.

The positive outcomes of the labor market and judicial reforms have been complemented by a number of measures to enhance business activity. Such measures include, among others, introduction of a one-stop shop for business registration, approval of the new Bankruptcy Law, and the Law on Audit. Furthermore, the number and complexity of licensing requirements will be reduced. To this end, by end-September 2006, the government will publish a list of all licenses administrated by line ministries and government agencies. In order to enhance transparency in the management of the state-owned assets, an annual report will be produced by the end of the year. 